\title{
U-PB ZIRCON AGES FROM BEDROCK SAMPLES COLLECTED IN THE TANACROSS AND NABESNA QUADRANGLES, EASTERN ALASKA
}

Alec D. Wildland, Alicja Wypych, Sean P. Regan, and Mark Holland

Preliminary Interpretive Report 2021-4

This publication has not been reviewed for technical content or for conformity to the editorial standards for DGGS.

2021

STATE OF ALASKA

DEPARTMENT OF NATURAL RESOURCES

DIVISION OF GEOLOGICAL \& GEOPHYSICAL SURVEYS
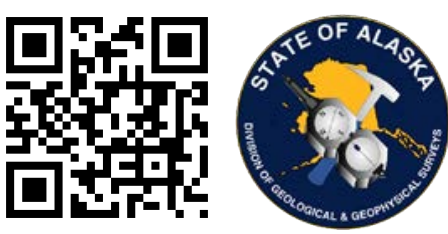
STATE OF ALASKA

Mike Dunleavy, Governor

DEPARTMENT OF NATURAL RESOURCES

Corri A. Feige, Commissioner

\section{DIVISION OF GEOLOGICAL \& GEOPHYSICAL SURVEYS}

Steve Masterman, State Geologist \& Director

Publications produced by the Division of Geological \& Geophysical Surveys are available to download from the DGGS website (dggs.alaska.gov). Publications on hard-copy or digital media can be examined or purchased in the Fairbanks office:

Alaska Division of Geological \& Geophysical Surveys (DGGS)

3354 College Road | Fairbanks, Alaska 99709-3707

Phone: 907.451.5010| Fax 907.451.5050

dggspubs@alaska.gov|dggs.alaska.gov

\section{DGGS publications are also available at:}

Alaska State Library, Historical

Collections \& Talking Book Center

395 Whittier Street

Juneau, Alaska 99801

Alaska Resource Library and

Information Services (ARLIS)

3150 C Street, Suite 100

Anchorage, Alaska 99503

\section{Suggested citation:}

Wildland, A.D., Wypych, Alicja, Regan, S.P., and Holland, Mark, 2021, U-Pb

zircon ages from bedrock samples collected in the Tanacross and Nabesna quadrangles, eastern Alaska: Alaska Division of Geological \& Geophysical Surveys Preliminary Interpretive Report 2021-4, 47 p.

\section{https://doi.org/10.14509/30732}
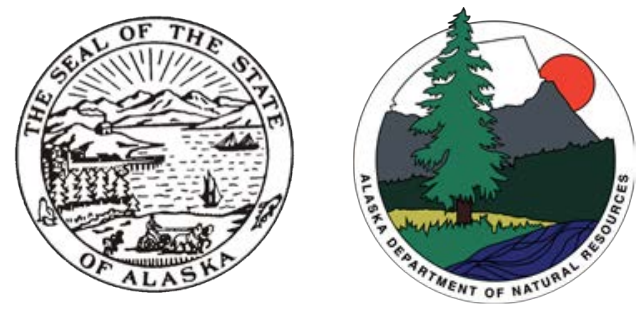


\section{Contents}

Introduction

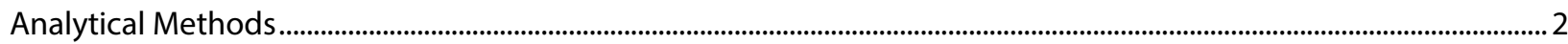

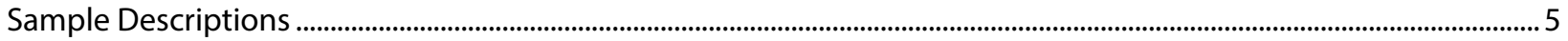

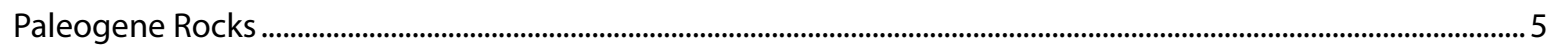

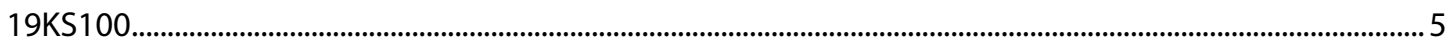

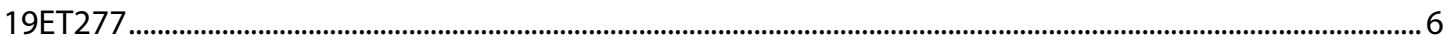

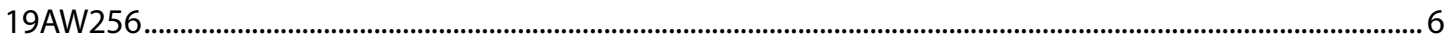

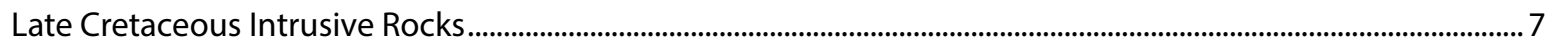

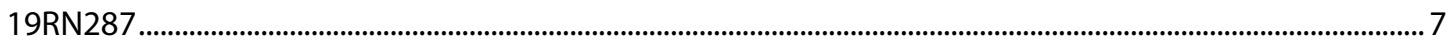

19WCW037

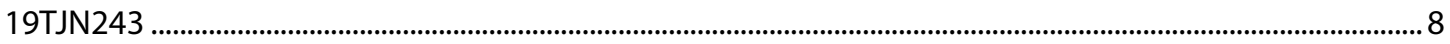

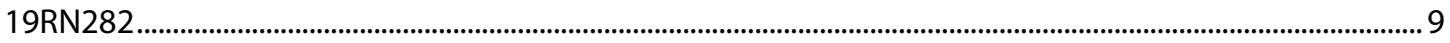

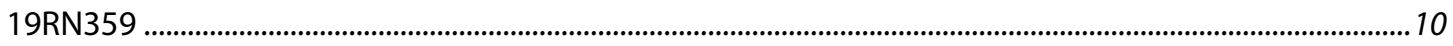

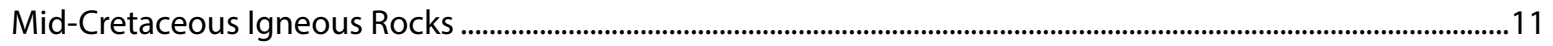

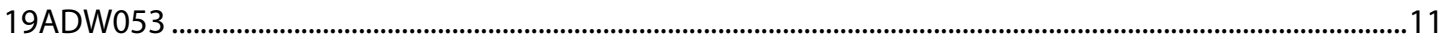

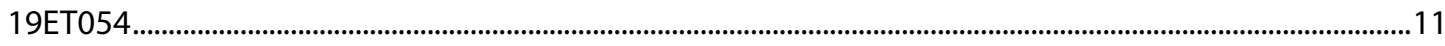

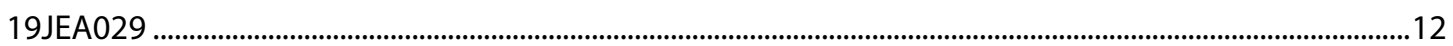

19ADW016

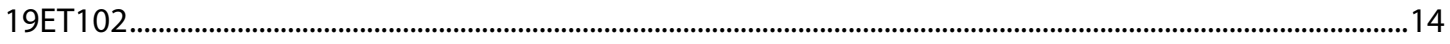

19ET288

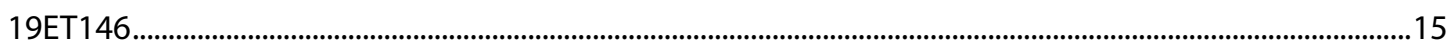

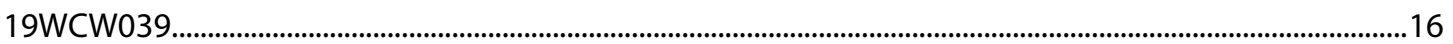

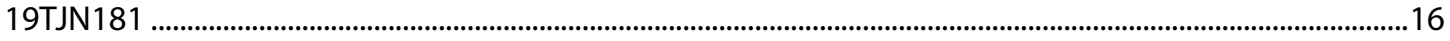

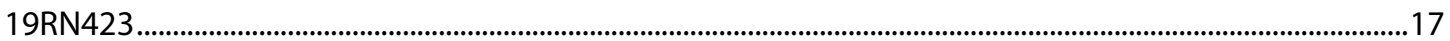

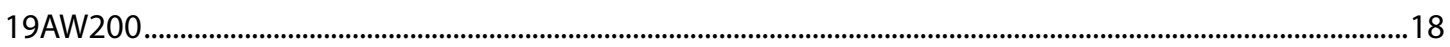

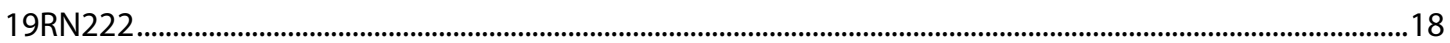

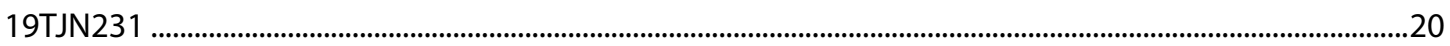

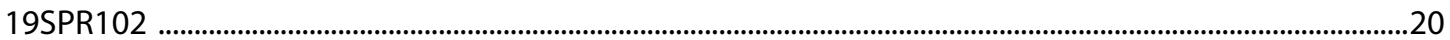

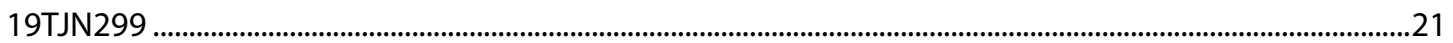

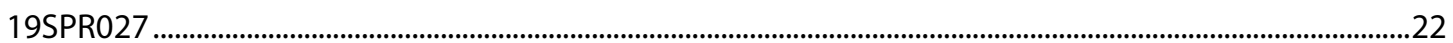

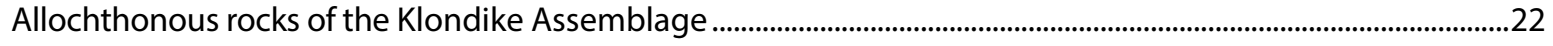

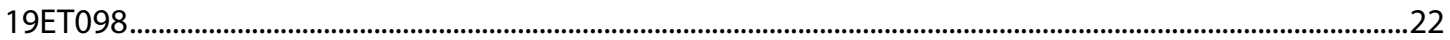

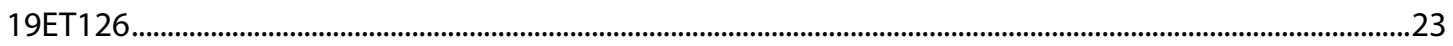

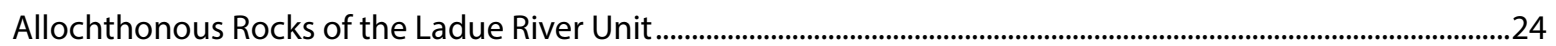

19WCW048

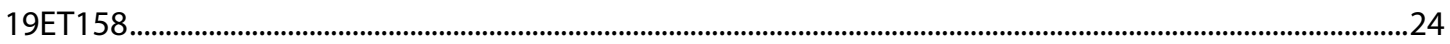

19ET045

19AW285

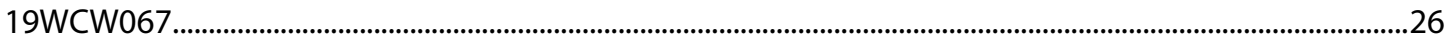

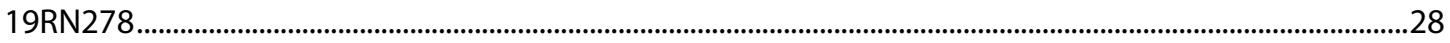

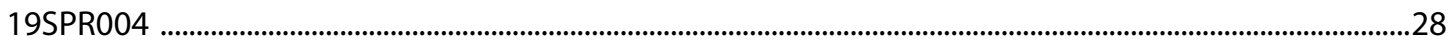

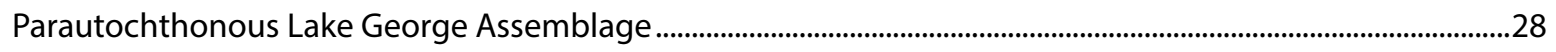

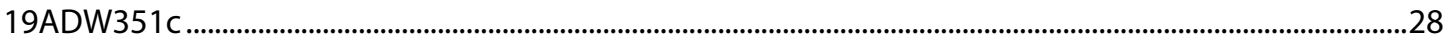

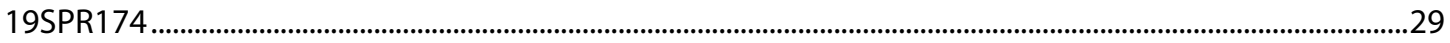

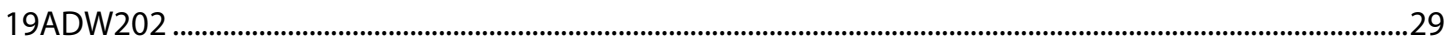




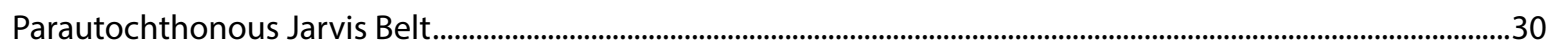

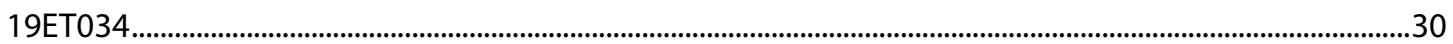

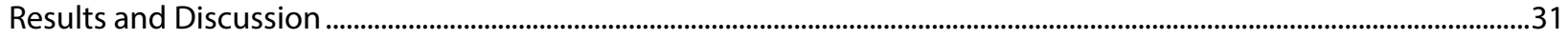

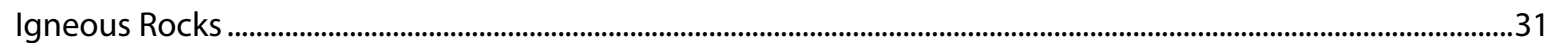

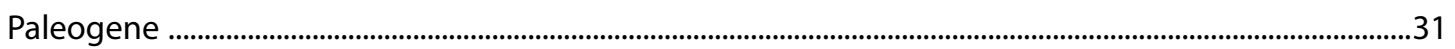

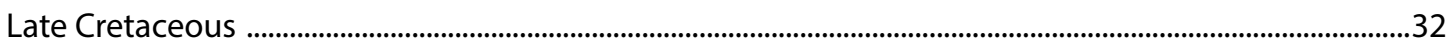

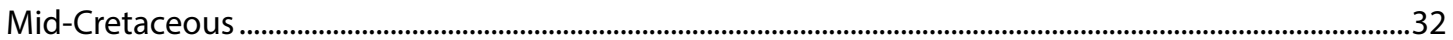

Allochthonous Metamorphic rocks ...................................................................................................................................

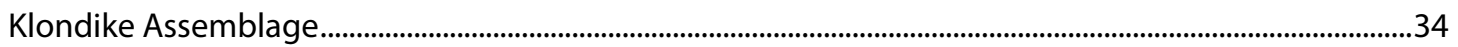

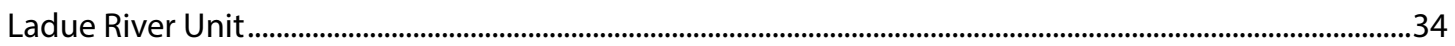

Parautochthonous Metamorphic rocks..........................................................................................................................

Lake George Assemblage ..................................................................................................................................

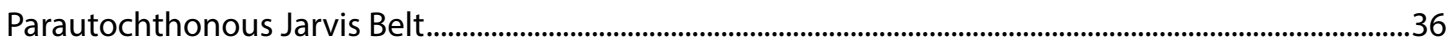

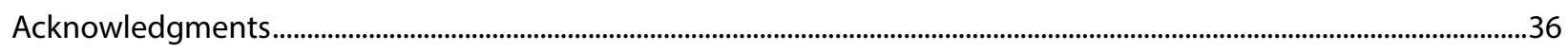

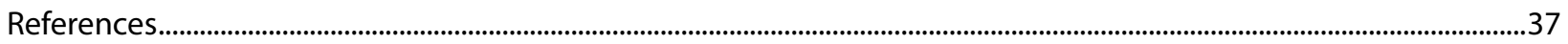

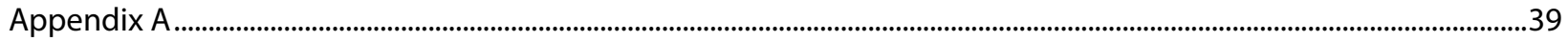




\title{
U-PB ZIRCON AGES FROM BEDROCK SAMPLES COLLECTED IN THE TANACROSS AND NABESNA QUADRANGLES, EASTERN ALASKA
}

\author{
Alec D. Wildland', Alicja Wypych'1, Sean P. Regan², and Mark Holland ${ }^{3}$ \\ INTRODUCTION
}

This Alaska Division of Geological \& Geophysical Surveys (DGGS) Preliminary Interpretive Report presents uranium-lead (U-Pb) ages of zircons from 37 igneous and metamorphic samples collected during the 2019 field season in support of a 4,800-sq-km (1,860-sq-mi) bedrock geologic map of eastern Interior Alaska surrounding Mount Fairplay and the Ladue River drainage (Twelker, 2021A). The area lies north of the Alaska Highway and is approximately $65 \mathrm{~km}$ (40 mi) east of Tok, Alaska; it runs west from the Alaska-Yukon border to encompass the Taylor Highway (fig. 1). DGGS and U.S. Geological Survey (USGS) staff identified this area as having underexplored potential to host deposits of critical minerals, including rare earth elements (REE), uranium, niobium, zirconium, tin, tungsten, bismuth, and rhenium, as well as conventional mineral resources including gold, copper, molybdenum, lead, zinc, and silver. The goal of this $\mathrm{U}$-Pb isotopic study is to better understand the Devonian through Paleogene magmatic and tectonic events, which have been linked to most of the known mineralization in the Yukon-Tanana Uplands.

The Mount Fairplay and Ladue River areas are characterized by amphibolite- to greenschist-facies metamorphic rocks - the Lake George assemblage, Ladue River unit, and the Klondike assemblagewhich have Mississippian-Devonian and Permian protolith ages (Day and others, 2002; Dusel-Bacon and others, 2006; Solie and others, 2014; Wypych and others, 2020; this report). U-Pb zircon geochronology results presented in this report show that these assemblages yield zircon crystallization ages consistent with previous workers (Dusel-Bacon and others, 2006; Jones and O'Sullivan, 2020; Wypych and others, 2020). Triassic plutons have previously been reported to be confined to the allochthonous Yukon-Tanana terrane (Dusel-Bacon and others, 2015) but were not observed in our field area. However, voluminous volcanic and plutonic rocks of varying composition and texture from the mid-Cretaceous (ca. 100-115 $\mathrm{Ma}$ ), Late Cretaceous (ca. 65-71 Ma), and Paleogene (ca. 57-58 Ma) magmatic episodes were observed to be emplaced in both the Lake George and Ladue River metamorphic units. Alaska DGGS and the USGS staff have identified both generations of Cretaceous magmatism as having potential to host deposits of the critical minerals mentioned above (Newberry, 2020; Twelker, 2021B).

The following products are included with this data release: a geochronology summary table, laboratory data, a data dictionary, and associated metadata. All components of this data release are available for download from the DGGS website: https://doi.org/10.14509/30732.

\footnotetext{
${ }^{1}$ Alaska Division of Geological \& Geophysical Surveys, 3354 College Road, Fairbanks, Alaska 99707

${ }^{2}$ Department of Geology \& Geophysics, University of Alaska, P.O. Box 755780, Fairbanks, Alaska 99775

${ }^{3}$ Department of Life, Earth, \& Environmental Sciences, West Texas A\&M University, 2501 4th Ave, Canyon, Texas 79016
} 


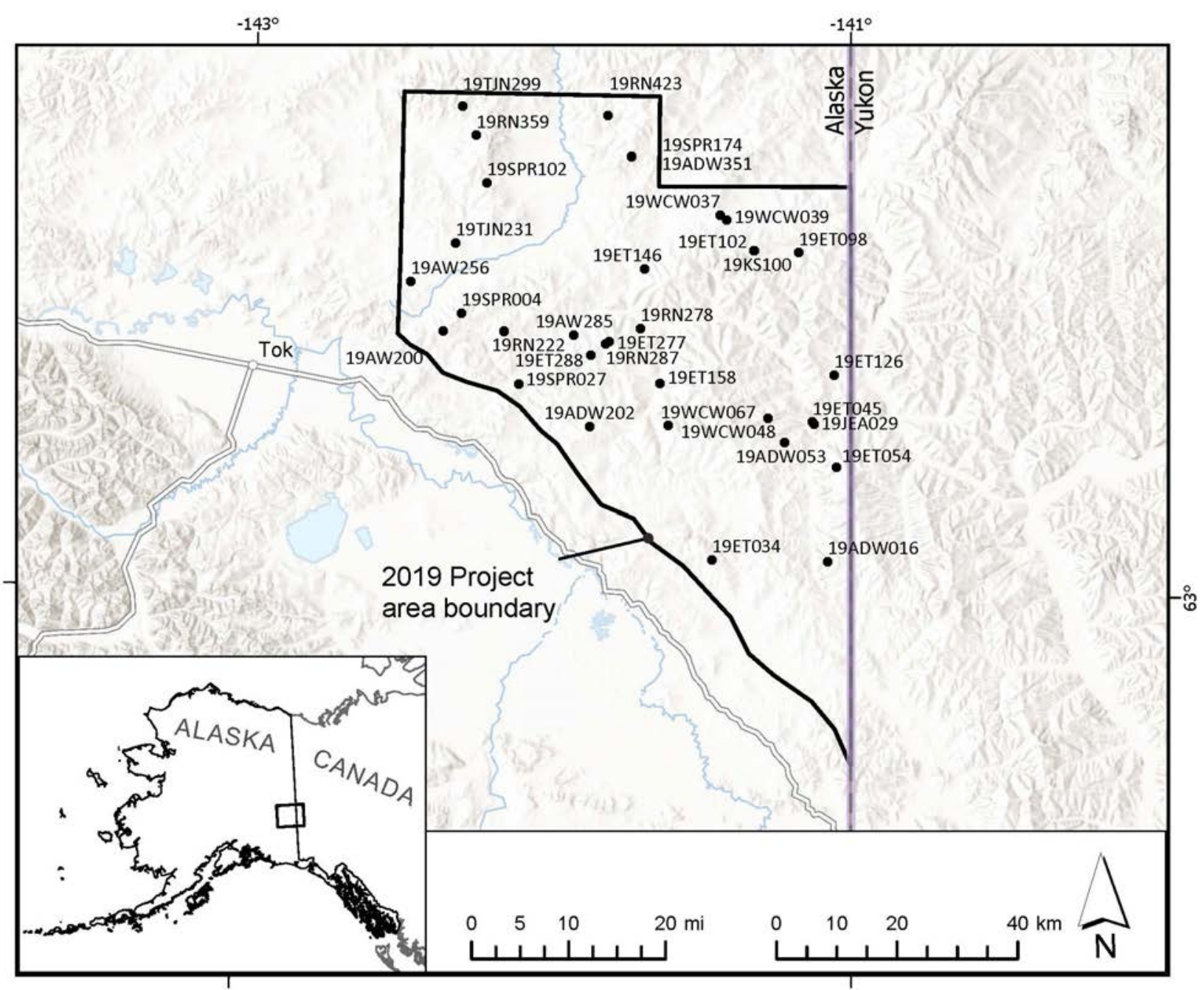

Figure 1. Map showing 2019 project area with locations of samples used for U-Pb analysis.

\section{ANALYTICAL METHODS}

Samples underwent standard zircon extraction procedures at the University of Arizona Laserchron Center. All samples were hand-cleaned, disaggregated in a jaw crusher, and pulverized by roller mill. Mineral separation was achieved by density contrast using a Wilfley Table and heavy liquids. Dense minerals were further subjected to magnetic separation using a Franz LB-1 magnetic barrier separator. Non-magnetic minerals were then placed in a hot nitric acid bath for approximately 15 minutes.

Approximately 50 zircon grains were obtained from the mineral separates of each sample and mounted together with appropriate zircon standards (see table 1) on a 1-inch $(2.5 \mathrm{~cm})$ round epoxy mount. The epoxy mount was then hand-polished and imaged by cathodoluminescence (CL). CL images were used to aid in zircon targeting during geochronologic analysis.

$\mathrm{U}-\mathrm{Pb}$ geochronology was conducted via laser ablation inductively coupled plasma mass spectrometry (LA-ICP-MS) at the University of Arizona Laserchron Center using the methods documented by Gehrels and others (2008). 35 zircon grains from each sample were targeted for U-Pb geochronologic analysis. Multiple analyses were conducted on some grains with complex internal textures (e.g., inherited cores and 
Table 1. Zircon standards used during the analysis.

\begin{tabular}{ccccc} 
Standard & Standard & $\begin{array}{c}\text { 206Pb/238U } \\
\text { age (Ma, } \mathbf{2 \sigma} \text { ) }\end{array}$ & $\begin{array}{c}\text { 206Pb/207Pb } \\
\text { age (Ma, } \mathbf{2 \sigma} \text { ( })\end{array}$ & \multicolumn{1}{c}{ Reference(s) } \\
R33 & Braintree Complex & $419.3 \pm 0.4$ & $422.37 \pm 0.36$ & Black and others (2004); Mattinson (2010) \\
\hline FC-1 & Duluth Complex & $1099.5 \pm 0.33$ & $1099.0 \pm 0.16$ & Paces and Miller (1993) \\
\hline SL2 & Sri Lanka F & $563.2 \pm 4.8 \mathrm{Ma}$ & $568 \pm 16 \mathrm{Ma}$ & Gehrels and others (2008)
\end{tabular}

magmatic overgrowths) revealed by CL imaging. Analysis locations were precleaned using a $30 \mu \mathrm{m}$ spot size set to three cycles. All analyses were performed using a $20 \mu \mathrm{m}$ spot size set to 110 cycles each, where the ablated material would then be carried by helium and/or argon gas to the plasma source. A series of standards were run at the beginning and end of each sample session and additionally between every three or five sample unknowns.

Crystallization ages were determined for each sample using a weighted mean of individual zircon dates. The analytical uncertainty of crystallization ages is presented at two standard deviations (also written as 2 -sigma or $2 \sigma$ ), with the final uncertainties consisting of random and systematic uncertainties added in quadrature. Uncertainties for the ages reported in table 2 include both analytical and systematic sources of uncertainty. We assumed a systematic uncertainty factor following the example of Coutts and others (2020), but we used a more conservative value of two percent $\left({ }^{206} \mathrm{~Pb} /{ }^{238} \mathrm{U} ; 2 \sigma\right.$; see Horstwood and others, 2016, and Spencer and others, 2016).

Data were filtered and the optimum age determined based on the following criteria: 1) only dates collected from zircon domains interpreted to record the youngest igneous crystallization event in the rock (e.g., magmatic overgrowths or grains with well-defined oscillatory zoning) were used, 2) anomalously old dates from grains with no obvious internal textural evidence for inheritance were interpreted to be xenocrysts and excluded. Even after this filtering, numerous samples yielded a suite of dates that do not define a single population (e.g., the mean square of weighted deviates [MSWD] is much greater than 1). In these cases, we followed the recommendations of Spencer and others (2016) and used only dates that overlapped within 2-sigma of the covaried uncertainty of the Tera-Wasserburg Concordia diagram.

Further, we attempted to identify Phanerozoic Pb-loss by two methods; 1) We compared U-Pb dates with uranium concentration. We interpreted a positive correlation between increasing uranium concentration and decreasing $\mathrm{U}-\mathrm{Pb}$ date to indicate $\mathrm{Pb}$-loss caused by radiogenic crystal lattice damage and excluded young dates from our age calculations. 2) When no correlation between $\mathrm{U}-\mathrm{Pb}$ date and uranium concentration was apparent we used kernel density estimation to identify potential $\mathrm{Pb}$-loss in populations with a negatively skewed tail (a trail of progressively younger dates) and excluded young dates from our calculations. Despite this treatment, some samples still yielded populations that do not conform to a single age population. In these cases, the weighted mean age is an approximation of the crystallization age of the pluton, and the true age may be either younger or older than the weighted mean owing to unresolvable Phanerozoic Pb-loss or inheritance. 
Table 2. Summary of best ages (the weighted-mean age) of analyzed zircon samples. Map units correspond to those in Twelker and others (2021) geologic map of the Mount Fairplay-Ladue area.

\begin{tabular}{|c|c|c|c|c|c|c|c|c|}
\hline & Sample & $\begin{array}{l}\text { Map } \\
\text { Unit }\end{array}$ & Lithology & Longitude & Latitude & $\begin{array}{c}{ }^{238} \mathrm{U} /{ }^{206} \mathrm{~Pb} \\
\text { best age } \\
(\mathrm{Ma})\end{array}$ & $\begin{array}{l}\text { Best } \\
\text { Age } \\
\text { error } \\
\text { (Ma) }\end{array}$ & MSWD \\
\hline \multirow{3}{*}{ Paleogene Rocks } & $19 \mathrm{KS} 100$ & Pefp & granite porphyry & -141.3235 & 63.5197 & 57.1 & 1.2 & 1.5 \\
\hline & $19 \mathrm{ET} 277$ & Pefp & rhyolite & -141.8030 & 63.3828 & 58.6 & 1.4 & 1.0 \\
\hline & 19AW256 & $\mathrm{PEr}$ & rhyolite & -142.4666 & 63.4673 & 58.9 & 1.4 & 1.0 \\
\hline \multirow{5}{*}{$\begin{array}{l}\text { Late Cretaceous } \\
\text { Intrusive Rocks }\end{array}$} & 19RN287 & IKpg & porphyritic granite & -141.8164 & 63.3791 & 68.8 & 1.5 & 0.9 \\
\hline & 19WCW037 & IKgd & granodiorite & -141.4382 & 63.5726 & 69.3 & 1.4 & 1.3 \\
\hline & 19TJN243 & IKgd & granodiorite & -141.8155 & 63.3848 & 71.4 & 1.4 & 2.1 \\
\hline & 19RN282 & IKgd & granodiorite & -141.8037 & 63.3836 & 72.1 & 1.6 & 1.1 \\
\hline & 19RN359 & IKfd & felsic dike & -142.2587 & 63.6871 & 70.5 & 1.6 & 1.9 \\
\hline \multirow{16}{*}{$\begin{array}{l}\text { Mid-Cretaceous } \\
\text { Igneous Rocks }\end{array}$} & 19ADW053 & Kmd & $\begin{array}{l}\text { mafic - intermediate alkalic } \\
\text { dikes }\end{array}$ & -141.2208 & 63.2340 & 100.3 & 2.2 & 3.3 \\
\hline & 19ET054 & Kgd & granodiorite & -141.0479 & 63.1975 & 104.2 & 2.3 & 1.7 \\
\hline & 19JEA029 & Kgd & granodiorite & -141.1235 & 63.2619 & 107.7 & 2.3 & 1.3 \\
\hline & 19ADW016 & Kmi & mafic to intermediate dikes & -141.0771 & 63.0578 & 102.8 & 2.2 & 3.3 \\
\hline & 19ET102 & Kmi & mafic to intermediate dikes & -141.3252 & 63.5203 & 110.7 & 2.5 & 1.2 \\
\hline & $19 \mathrm{ET} 288$ & $\mathrm{Kg}$ & granite & -141.8630 & 63.3617 & 106.7 & 2.3 & 1.6 \\
\hline & $19 \mathrm{ET} 146$ & $\mathrm{Kg}$ & granite & -141.6891 & 63.4919 & 107.9 & 2.4 & 0.9 \\
\hline & 19WCW039 & $\mathrm{Kg}$ & granite & -141.4154 & 63.5658 & 109.1 & 2.2 & 12.0 \\
\hline & 19TJN181 & $\mathrm{Kg}$ & granite & -142.1536 & 63.3958 & 109.7 & 2.2 & 2.9 \\
\hline & $19 R N 423$ & $\mathrm{Kg}$ & granite & -141.8181 & 63.7192 & 112.8 & 2.6 & 2.6 \\
\hline & 19AW200 & Kgp & granite porphyry & -142.3554 & 63.3948 & 107.2 & 2.4 & 2.5 \\
\hline & 19RN222 & Kgp & granite porphyry & -142.1532 & 63.3957 & 109.2 & 2.4 & 1.5 \\
\hline & 19TJN231 & Kgp & granite porphyry & -142.3200 & 63.5260 & 111.8 & 2.2 & 2.0 \\
\hline & 19SPR102 & Kgp & granite porphyry & -142.2189 & 63.6166 & 115.0 & 2.5 & 4.0 \\
\hline & 19TJN299 & Kwff & felsic tuff & -142.3061 & 63.7295 & 107.9 & 2.2 & 1.3 \\
\hline & 19SPR027 & Kgb & gabbro to diorite & -142.1020 & 63.3172 & 108.1 & 2.3 & 2.7 \\
\hline \multirow{2}{*}{$\begin{array}{c}\text { Klondike } \\
\text { Assemblage }\end{array}$} & 19ET098 & Pks & schist & -141.1760 & 63.5173 & 256.7 & 5.8 & 1.0 \\
\hline & 19ET126 & Pks & schist & -141.0576 & 63.3351 & 261.4 & 5.8 & 0.9 \\
\hline \multirow{7}{*}{ Ladue River Unit } & 19WCW048 & MDpo & $\begin{array}{c}\text { Feldspar-porphyroclastic } \\
\text { orthogneiss }\end{array}$ & -141.2756 & 63.2706 & 359.7 & 7.2 & 2.3 \\
\hline & $19 \mathrm{ET} 158$ & $\mathrm{MDa}$ & amphibolite & -141.6333 & 63.3207 & 361.8 & 7.4 & 1.6 \\
\hline & 19ET045 & $\mathrm{MDg}$ & metagranitoid & -141.1283 & 63.2652 & 360.7 & 7.8 & 4.0 \\
\hline & 19AW285 & $\mathrm{MDg}$ & metagranitoid & -141.9208 & 63.3916 & 363.0 & 7.9 & 1.7 \\
\hline & 19WCW067 & $\mathrm{MDg}$ & metagranitoid & -141.6044 & 63.2584 & 364.9 & 7.3 & 1.7 \\
\hline & 19RN278 & $\mathrm{MDg}$ & metagranitoid & -141.7008 & 63.4027 & 370.1 & 8.4 & 0.9 \\
\hline & 19SPR004 & $\mathrm{MDg}$ & metagranitoid & -142.2953 & 63.4218 & 375.7 & 9.0 & 1.1 \\
\hline \multirow{3}{*}{$\begin{array}{l}\text { Lake George } \\
\text { Assemblage }\end{array}$} & 19ADW351C & MDag & granite orthogneiss & -141.7359 & 63.6588 & 360.7 & 8.7 & 0.8 \\
\hline & 19SPR174 & MDag & granite & -141.7359 & 63.6587 & 367.6 & 8.4 & 5.8 \\
\hline & 19ADW202 & MDlo & leucogranite & -141.8652 & 63.2561 & 370.6 & 8.3 & 2.7 \\
\hline $\begin{array}{l}\text { Parautochthonous } \\
\text { Jarvis Belt }\end{array}$ & 19ET034 & MDmr & metarhyolite & -141.4573 & 63.0598 & 366.8 & 8.1 & 2.2 \\
\hline
\end{tabular}




\section{SAMPLE DESCRIPTIONS}

The following sample descriptions are based on field notes and thin-section petrography as well as cathodoluminescence photography for zircon grains. Summary of the weighted-mean ages of analyzed zircon samples can be found in table 2. Thin section images can be found in Appendix A where they are presented in the same order as the sample descriptions below. Note that plane polarized light (PPL) images are on the left and crossed polarized light (XPL) images are on the right.

\section{Paleogene Rocks $19 K S 100$}

Quartz-rich porphyry intrusion from the Pushbush prospect area; tan to orange; massive; porphyritic; aphanitic groundmass; grain size: 0.01 to $6 \mathrm{~mm}$; mineralogy: 10 percent quartz (euhedral), 3 percent feldspar (euhedral), two percent oxides, minor biotite and chlorite, and greater than 80 percent groundmass. Quartz is 0.5 to $2 \mathrm{~mm}$, euhedral, partially fractured, and granoblastic texture with feldspar. Plagioclase is 0.5 to $2 \mathrm{~mm}$, euhedral, common polysynthetic twins, and sericite replacement. Biotite and opaques minor in groundmass, 0.05 to $0.1 \mathrm{~mm}$. Chlorite blades are 0.5 to $1 \mathrm{~mm}$ and altered from biotite. Rock sample is overall porphyritic with some granophyric textures. The groundmass is altered and somewhat recrystallized. The sample is partially weathered and was collected from subcrop.

Sample 19KS100 yielded a population of subhedral and elongated, but often broken with missing parts, zircon crystals ranging in length between 150-200 $\mu \mathrm{m}$ (fig. 2A). Oscillatory zonation is common with lesser sector zonation present. Zircon crystals contain frequent inclusions. Inherited cores with damage and fracturing noted but less common.

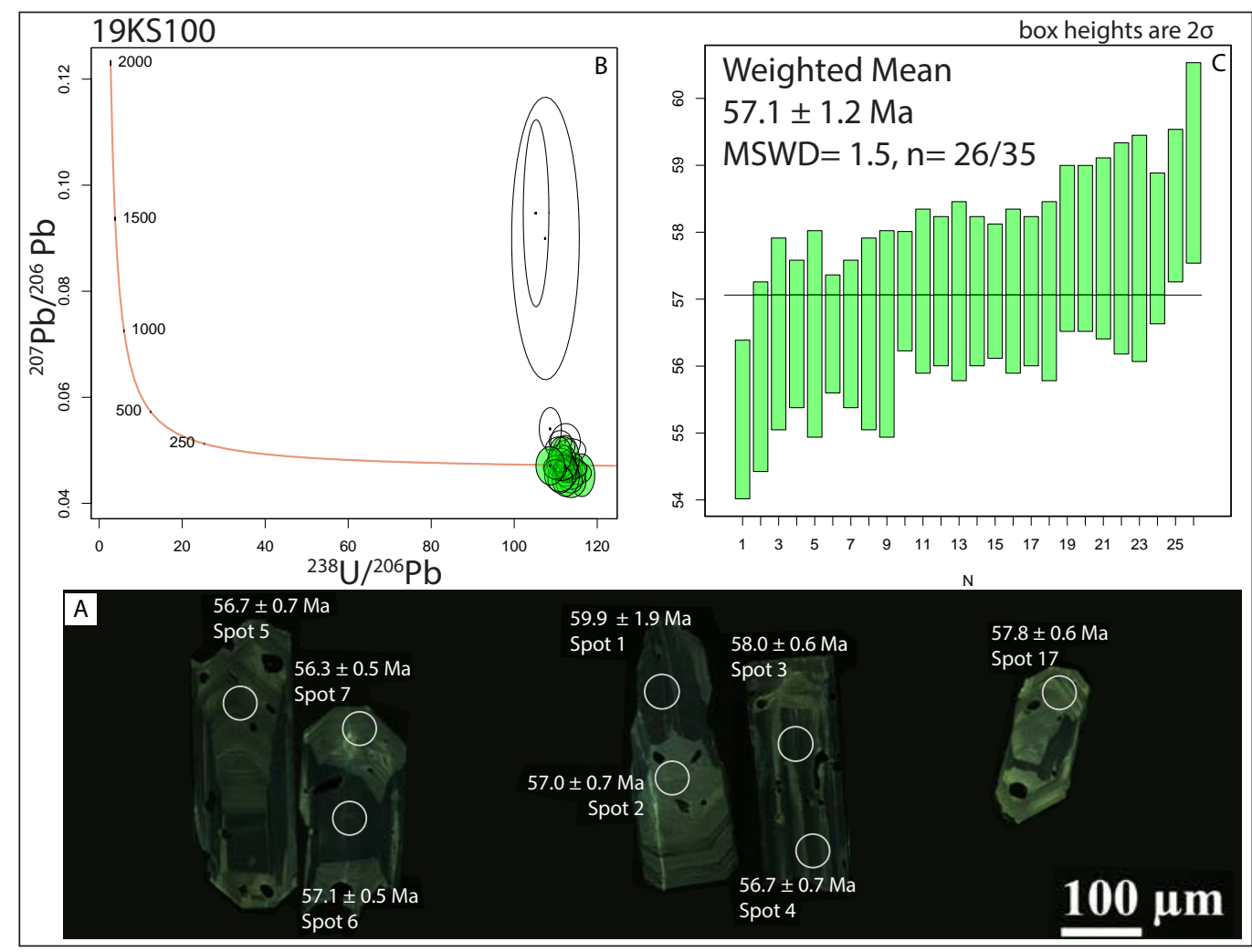

Figure 2. U-Pb data for sample 19KS100. A. Cathodoluminescence images of representative zircon population with spot location and age. B. Tera-Wasserburg concordia diagram. C. Plot of ${ }^{206} \mathrm{~Pb} / 238 \mathrm{U}$ ages with weighted average of preferred ages. Ovals and bars indicate uncertainty at the 2-sigma level. 


\section{$19 E T 277$}

Rhyolite from the Oreo Mountain prospect area; orange-brown; porphyritic; coherent; grain size: 0.01 to $3 \mathrm{~mm}$; mineralogy: one percent quartz (phenocrystic) and one percent plagioclase (phenocrystic). Sample contains $0.5-1 \mathrm{~mm}$ euhedral quartz phenocrysts, some aggregated in clusters. Plagioclase phenocrysts are 1-3 mm, fresh, and subhedral. The matrix is glassy and is partially devitrified into 100-500 $\mu \mathrm{m}$ spherulites. Acicular, sub-millimeter mineral present in the glassy matrix. Weathering is fracture controlled. Sample taken from float.

Sample 19ET277 yielded a population of anhedral to subhedral, typically elongated crystals with long axes ranging in length between $75-150 \mu \mathrm{m}$ (fig. 3A). There is evidence of damaged cores, fractures, and holes(?) (up to $20-25 \mu \mathrm{m}$ in size), which were avoided during analysis. Zonation is primarily oscillatory, however, there are several zircon grains that show recrystallized domains with irregular textures and/or missing parts.

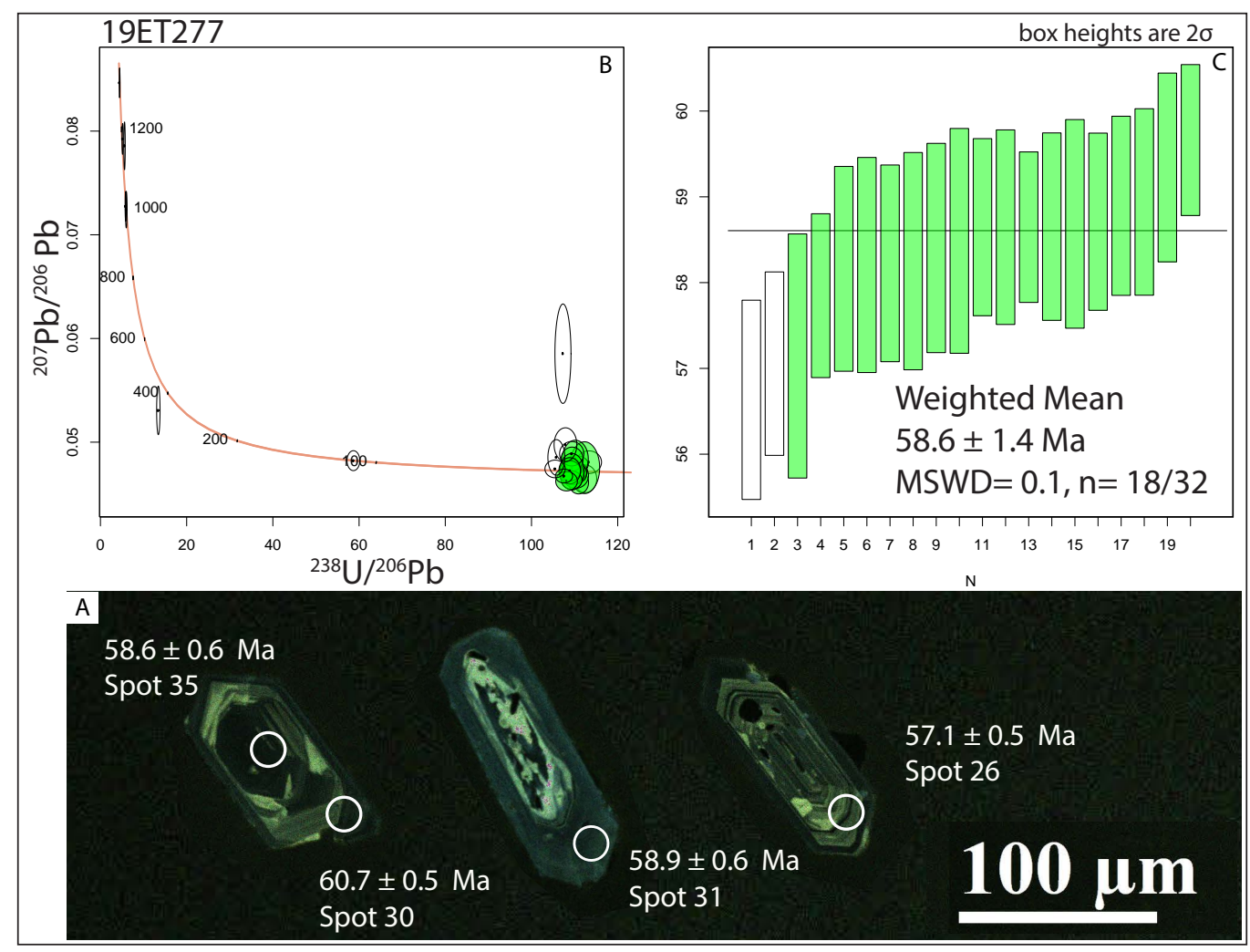

Figure 3. U-Pb data for sample 19ET277. A. Cathodoluminescence images of representative zircon population with spot location and age. B. Tera-Wasserburg concordia diagram. C. Plot of ${ }^{206} \mathrm{~Pb} / 238 \mathrm{U}$ ages with weighted average of preferred ages. Ovals and bars indicate uncertainty at the 2-sigma level.

\section{$19 A W 256$}

Rhyolite; pale gray, weathering brown; porphyritic; grain size: 0.01 to $2 \mathrm{~mm}$; mineralogy: 10 percent quartz, five percent feldspar, and two percent lithic clasts. Weathering: trace. Up to $2 \mathrm{~mm}$ subhedral, often subrounded, partially resorbed quartz, and $1 \mathrm{~mm}$ euhedral feldspar form phenocrysts in a fine-grained, devitrified groundmass. Lithic clasts are small, angular, and frequently fragmented. The rock has enclaves of creamy colored material. 
Sample 19AW256 yielded a population of subhedral and equant to elongated zircon crystals with long axes ranging in length from 100-120 $\mu \mathrm{m}$ (fig. 4A). Internal textures are difficult to observe because more than 90 percent of zircon crystals are CL-dark, with some having CL-bright domains or rims too narrow to analyze. However, faint oscillatory zonation can be seen, and ages are interpreted to be primarily magmatic.

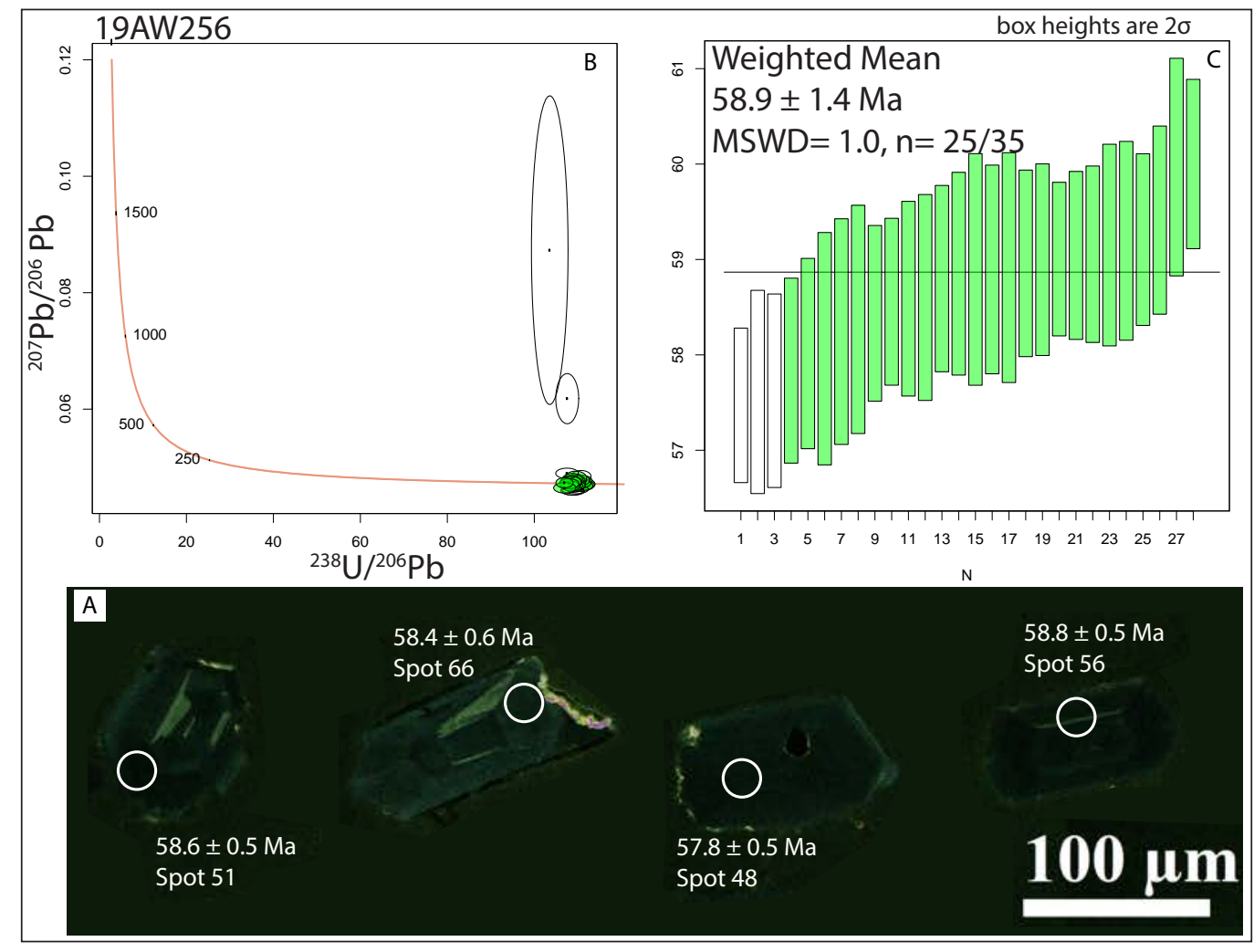

Figure 4. U-Pb data for sample 19AW256. A. Cathodoluminescence images of representative zircon population with spot location and age. B. Tera-Wasserburg concordia diagram. C. Plot of ${ }^{206} \mathrm{~Pb} / 238 \mathrm{U}$ ages with weighted average of preferred ages. Ovals and bars indicate uncertainty at the 2-sigma level.

\section{Late Cretaceous Intrusive Rocks 19RN287}

Biotite-hornblende granite near Oreo Mountain prospect; pink-gray; jointed; porphyritic; hypidiomorphic; grain size: 1 to $20 \mathrm{~mm}$. Overall coarse-grained and porphyritic granite with common sericite and chlorite alteration. Mineralogy: 30 percent plagioclase, 20 percent K-feldspar, 20 percent quartz, 15 percent hornblende, 10 percent biotite, three percent magnetite, two percent titanite, and secondary chlorite and sericite. Plagioclase crystals are typically 2 to $5 \mathrm{~mm}$, euhedral, commonly twinned, and have strong sericite replacement. K-feldspar is $2 \mathrm{~mm}$, sub- to euhedral, fractured, and weathered with biotite and titanite inclusions. Quartz is 0.5 to $1 \mathrm{~mm}$, shows undulatory extinction, and is often found near titanite. Hornblende is typically $1 \mathrm{~mm}$ long, sub- to euhedral, and has well defined cleavage, with partial chlorite replacement. Biotite is 1 to $1.5 \mathrm{~mm}$ and fresh looking, with minor chlorite replacement and large zircon and metamict zones. Chlorite forms as clots near or on the biotite and hornblende crystals. Weathering is fracture controlled.

Sample 19RN287 yielded a population of subhedral and elongated zircon crystals with long axes ranging in length from 100-125 $\mu \mathrm{m}$ (fig. 5A). Internal textures and ages were interpreted to be primarily 


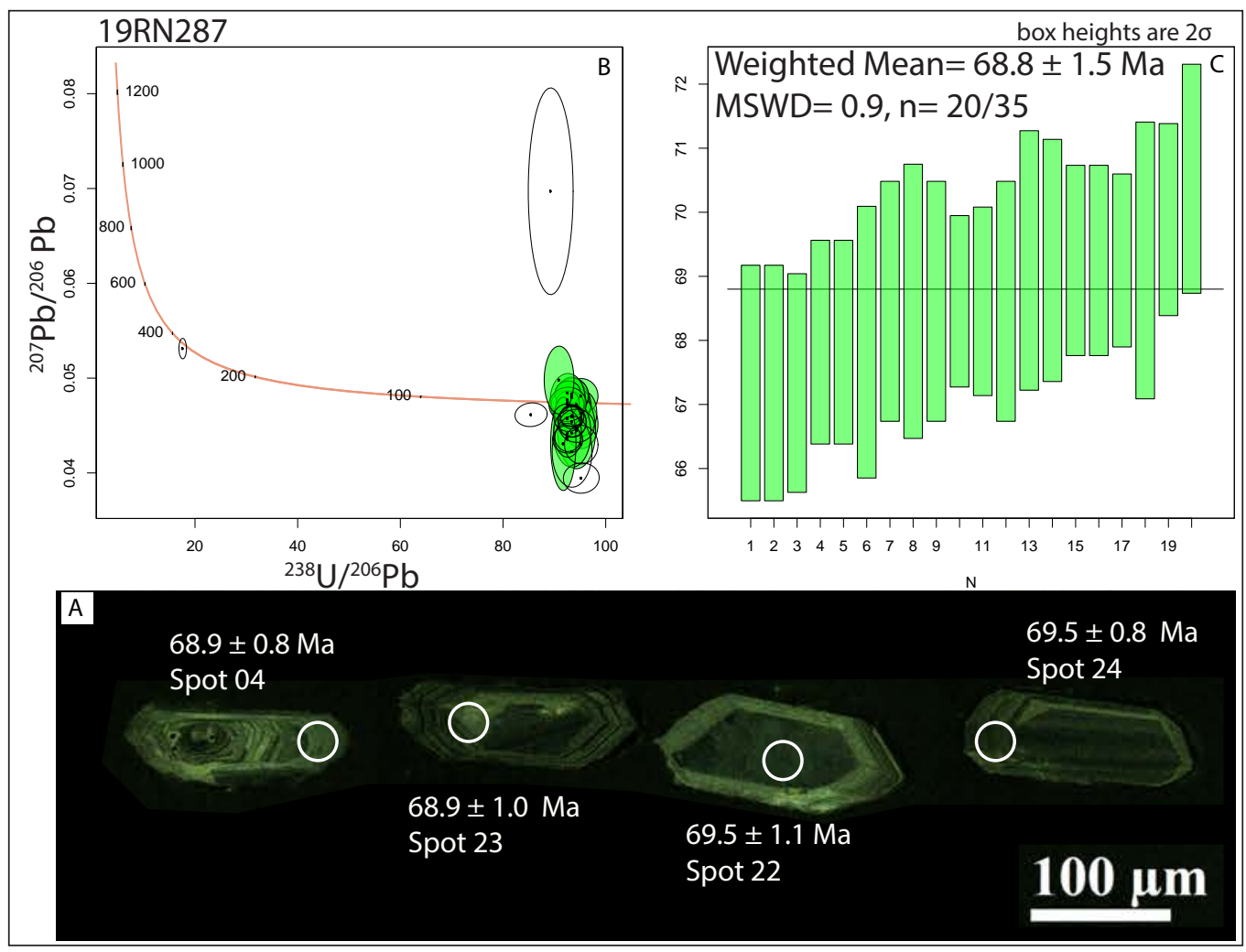

Figure 5. U-Pb data for sample 19RN287. A. Cathodoluminescence images of representative zircon population with spot location and age. B. Tera-Wasserburg concordia diagram. C. Plot of ${ }^{206} \mathrm{~Pb} /{ }^{238} \mathrm{U}$ ages with weighted average of preferred ages. Ovals and bars indicate uncertainty at the 2-sigma level.

igneous with oscillatory zonation. Crystals with cores and rims are present but not abundant. Few crystals display irregular textures possibly indicating recrystallization or newly grown domains. Fracturing and broken crystals are infrequent.

\section{WCW037}

Porphyritic granodiorite; gray-green, pink; slabby; equigranular; grain size: 0.5 to $8 \mathrm{~mm}$. Mineralogy: 50 percent plagioclase (randomly oriented tabular plagioclase laths), 25 percent hornblende (phenocrysts, strong chlorite replacement), 20 percent biotite (strong chlorite replacement), 3 percent quartz, and 2 percent opaque minerals. Weathering: trace. Elevated magnetic susceptibility. Sample taken from subcrop.

Sample 19WCW037 yielded a population of subhedral and elongated zircon crystals ranging in length between 100-125 $\mu \mathrm{m}$ (fig. 30). Internal textures of CL-medium to bright crystals are primarily magmatic, displaying oscillatory and sector zonation, with several crystals containing inherited cores. CL-dark crystals (30-40 percent) were interpreted to be metamict and avoided during analysis.

\section{TJN243}

Intrusive granodiorite porphyry from the Oreo Mountain prospect area; grain size: 0.5 to $5 \mathrm{~mm}$; mineralogy: three percent plagioclase (2 to $5 \mathrm{~mm}$ phenocrysts, euhedral to subhedral), hornblende (chloritized), three percent clinopyroxene (euhedral phenocrysts 1 to $2 \mathrm{~mm}$, six sided, single twins common; not chloritized; second order colors, not pleochroic), two percent relict biotite (phenocrysts 1 to $2 \mathrm{~mm}$, equant 


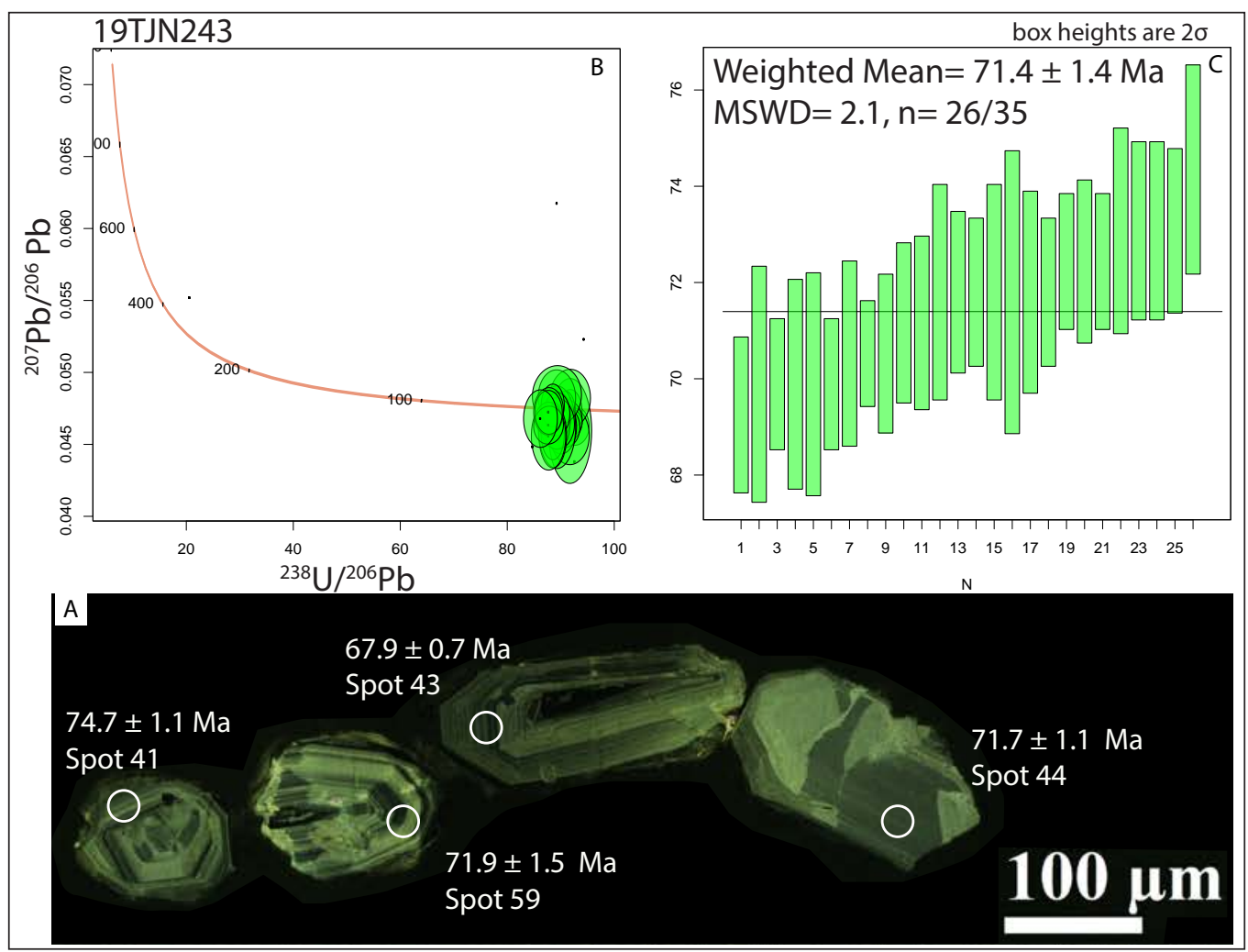

Figure 6. U-Pb data for sample 19TJN243. A. Cathodoluminescence images of representative zircon population with spot location and age. B. Tera-Wasserburg concordia diagram. C. Plot of ${ }^{206} \mathrm{~Pb} / 238 \mathrm{U}$ ages with weighted average of preferred ages. Ovals and bars indicate uncertainty at the 2-sigma level.

rectangular; now entirely to chlorite and sulfide), and groundmass (50 $\mu \mathrm{m}$ or less grain size). Disseminated chalcopyrite and possible pyrite were noted in the hand sample. Weathering: trace. Sample taken from float.

Sample 19TJN243 yielded a population of subhedral, equant and lesser elongated, zircon crystals with long axes typically ranging from 100 to $250 \mu \mathrm{m}$ in length (fig. 6A). Internal textures are primarily igneous with oscillatory and lengthwise zonation. Occasional crystal has an inherited core and rim texture. These cores can be metamict and display a convolute zonation. Majority of crystals are intact but can be fractured and have missing parts.

\section{RN282}

Altered felsic dike of granodiorite composition, Oreo Mountain prospect; pale; jointed; aphanitic; porphyritic; grain size: 0.01 to $5 \mathrm{~mm}$; mineralogy: 10 percent sericite, five percent pyrite (disseminated), two percent quartz (phenocrystic), and one percent plagioclase. Sample contains 1 to $4 \mathrm{~mm}$ quartz and 1 to $5 \mathrm{~mm}$ sericitized plagioclase phenocrysts in an altered matrix. The rock contains disseminated pyrite, stockwork quartz veinlets, and sericite veins. Weathering: pervasive. Sample collected from subcrop.

Sample 19RN282 yielded a population of euhedral and lesser subhedral, equant to elongated zircon crystals with varying sizes (fig. 7A). Half the zircon population is estimated to be $75-100 \mu \mathrm{m}$ in length while the larger half typically ranges between 150-200 $\mu \mathrm{m}$. Internal textures are primarily igneous (i.e., oscillatory and lengthwise zonation); however, about 30 percent of the population were interpreted to have 


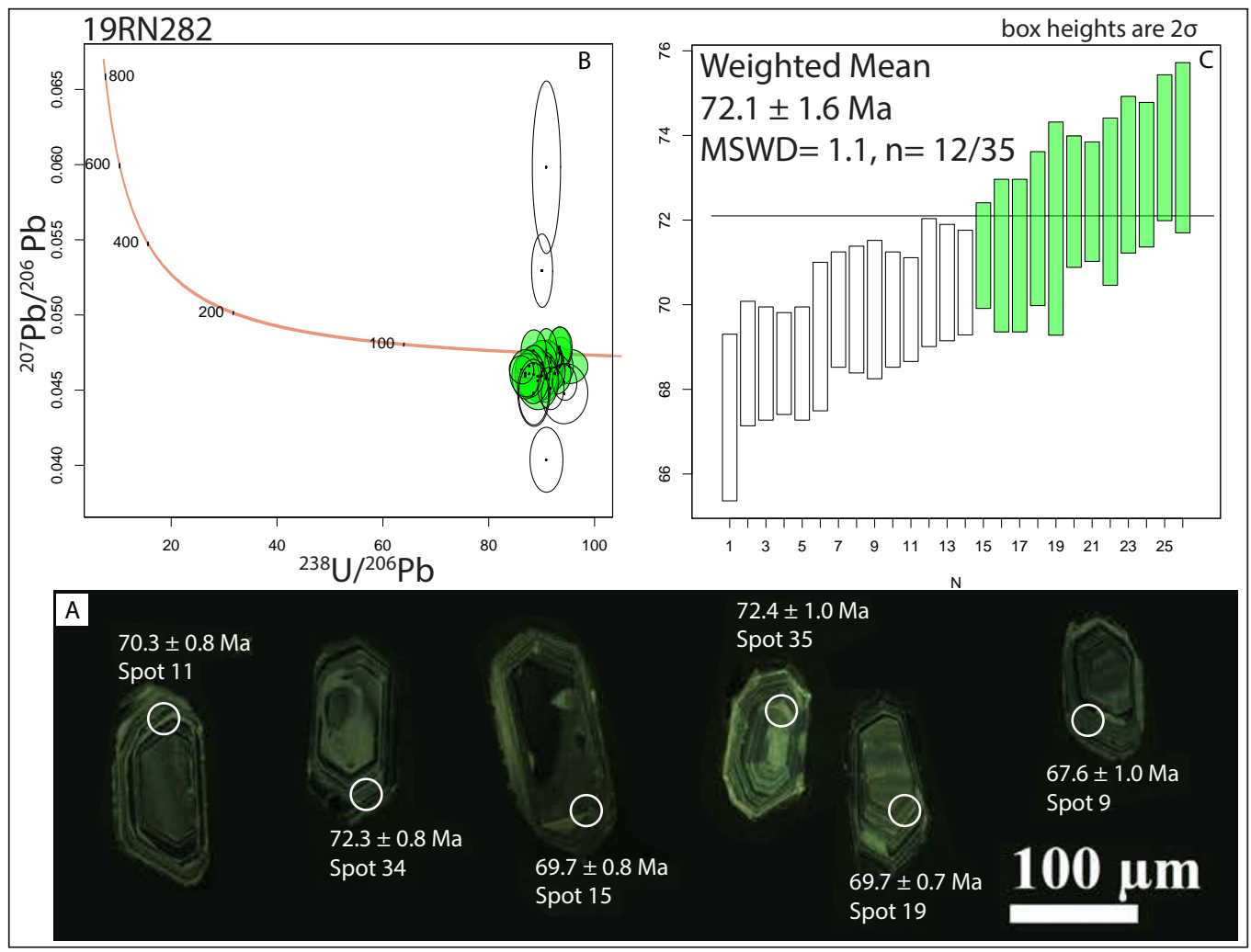

Figure 7. U-Pb data for sample 19RN282. A. Cathodoluminescence images of representative zircon population with spot location and age. B. Tera-Wasserburg concordia diagram. C. Plot of ${ }^{206} \mathrm{~Pb} /{ }^{238} \mathrm{U}$ ages with weighted average of preferred ages. Ovals and bars indicate uncertainty at the 2-sigma level.

experienced lead loss and display irregular zonation or recrystallized domains possibly associated with that event. Inherited or xenocrystic cores are present but not pervasive. Several zircon crystals were CL-dark, interpreted to be metamict, and avoided during analysis.

\section{RN359}

Altered felsic dike of granitic composition, Mount Fairplay prospect; white; jointed; aphanitic; porphyritic; grain size: 0.01 to $5 \mathrm{~mm}$; mineralogy: 20 percent feldspar, 15 percent quartz (phenocrystic), five percent sericite, one percent pyrite (disseminated), and two percent tourmaline aggregates. Feldspar is up to $0.5 \mathrm{~mm}$, simple and lamellae twins, and is highly altered to sericite. Quartz phenocrysts are 0.1 to $0.3 \mathrm{~mm}$ and sub- to euhedral. Sericite and pyrite are disseminated. Tourmaline is rare and appears as light brown aggregates with an anhedral crystal shape. Possible white mica in groundmass. Contains about 1 percent iron oxide after pyrite. The sample was observed to have stockwork mineralization, silicification, and fracture-controlled weathering. Sample was collected from an outcrop.

Sample 19RN359 yielded a population of subhedral, elongated, and lesser equant zircon crystals with long axes ranging in length between $75-100 \mu \mathrm{m}$ (up to $250 \mu \mathrm{m}$; fig. 8A). Internal textures are primarily igneous and display oscillatory zonation. Inherited cores are common and also display igneous textures. Several crystals are fractured with missing parts and have experienced varying degrees of resorption, as shown by their rounded or embayed textures. 


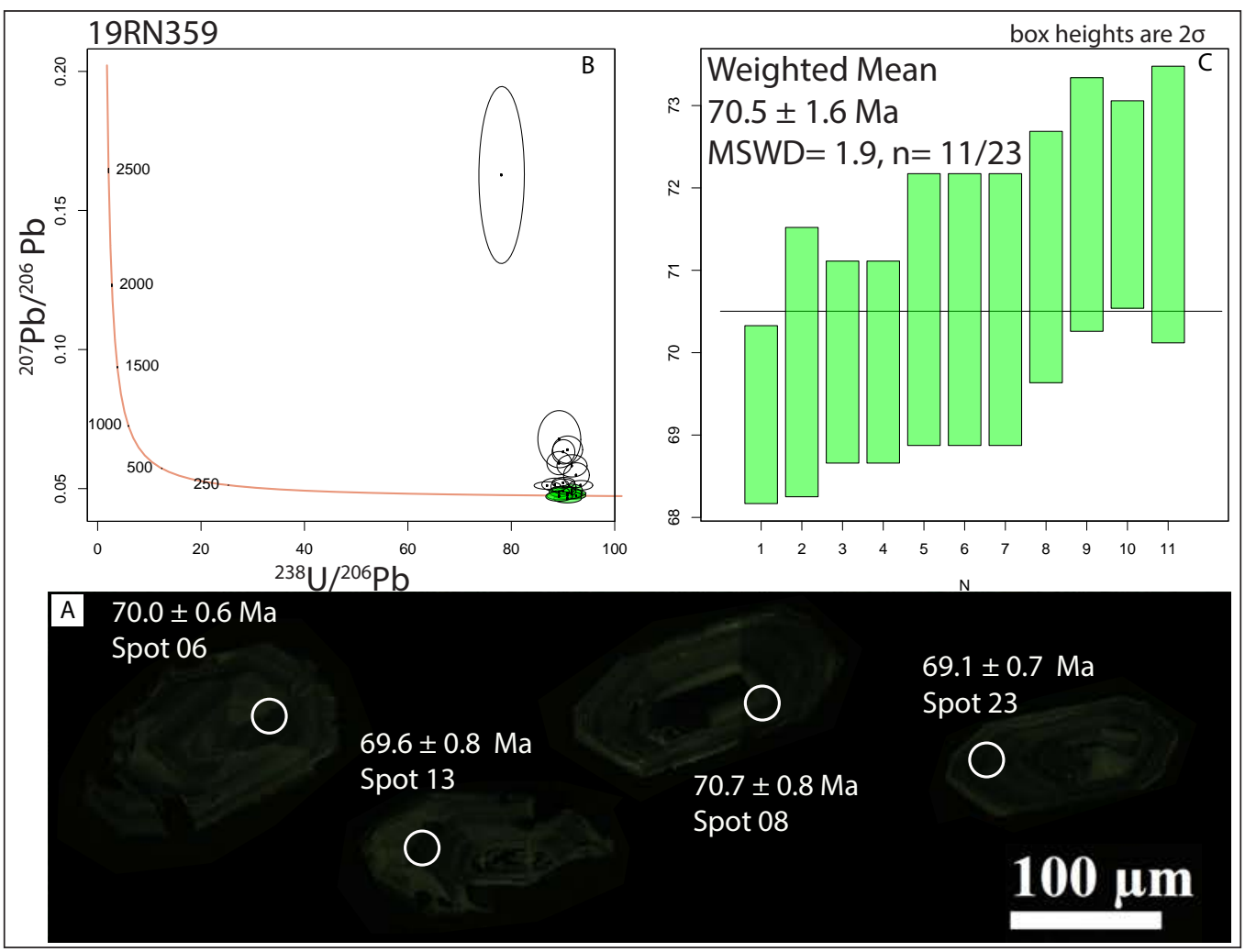

Figure 8. U-Pb data for sample 19RN359. A. Cathodoluminescence images of representative zircon population with spot location and age. B. Tera-Wasserburg concordia diagram. C. Plot of ${ }^{206} \mathrm{~Pb} /{ }^{238} \mathrm{U}$ ages with weighted average of preferred ages. Ovals and bars indicate uncertainty at the 2-sigma level.

\section{Mid-Cretaceous Igneous Rocks 19ADW053}

Granodiorite dike; gray; porphyritic; grain size: 1 to $4 \mathrm{~mm}$; mineralogy: 15 percent quartz phenocrysts, 15 percent hornblende, 15 percent calcite, five percent biotite, five percent plagioclase phenocrysts, and 45 percent groundmass. Quartz phenocrysts are rounded and partially resorbed. Biotite is fine- to medium-grained and largely chloritized. Plagioclase is sericitized. Hornblende is largely chloritized, with some skeletal crystals present. The groundmass is composed of very fine-grained quartz, feldspar, and biotite-a product of devitrification of glass. Some secondary calcite fills vugs or possibly vesicles.

Sample 19ADW053 yielded a population of equant to elongated and euhedral zircon crystals with long axes that are typically $100-150 \mu \mathrm{m}$ in length (fig. 9A). Oscillatory zonation in the rims and lengthwise zonation are common. The majority of analysis spots were placed on CL-bright zones frequently located in the middle to rim areas of the crystals. CL-dark grains (50-60 percent of population) and cores are common, were interpreted to be metamict, and were avoided during analysis due to damage.

\section{$19 E T 054$}

Granodiorite; white and black; equigranular; grain size: 2 to $5 \mathrm{~mm}$; mineralogy: 55 percent plagioclase, 25 percent quartz, 15 percent microcline, five percent biotite, one percent hornblende, and one percent chlorite. Contains 2 to $5 \mathrm{~mm}$ long plagioclase is partially sericitized, whereas 1 to $2 \mathrm{~mm}$ long, tartan-twinned microcline is unaltered. Quartz often forms granoblastic aggregates and has undulose extinc- 


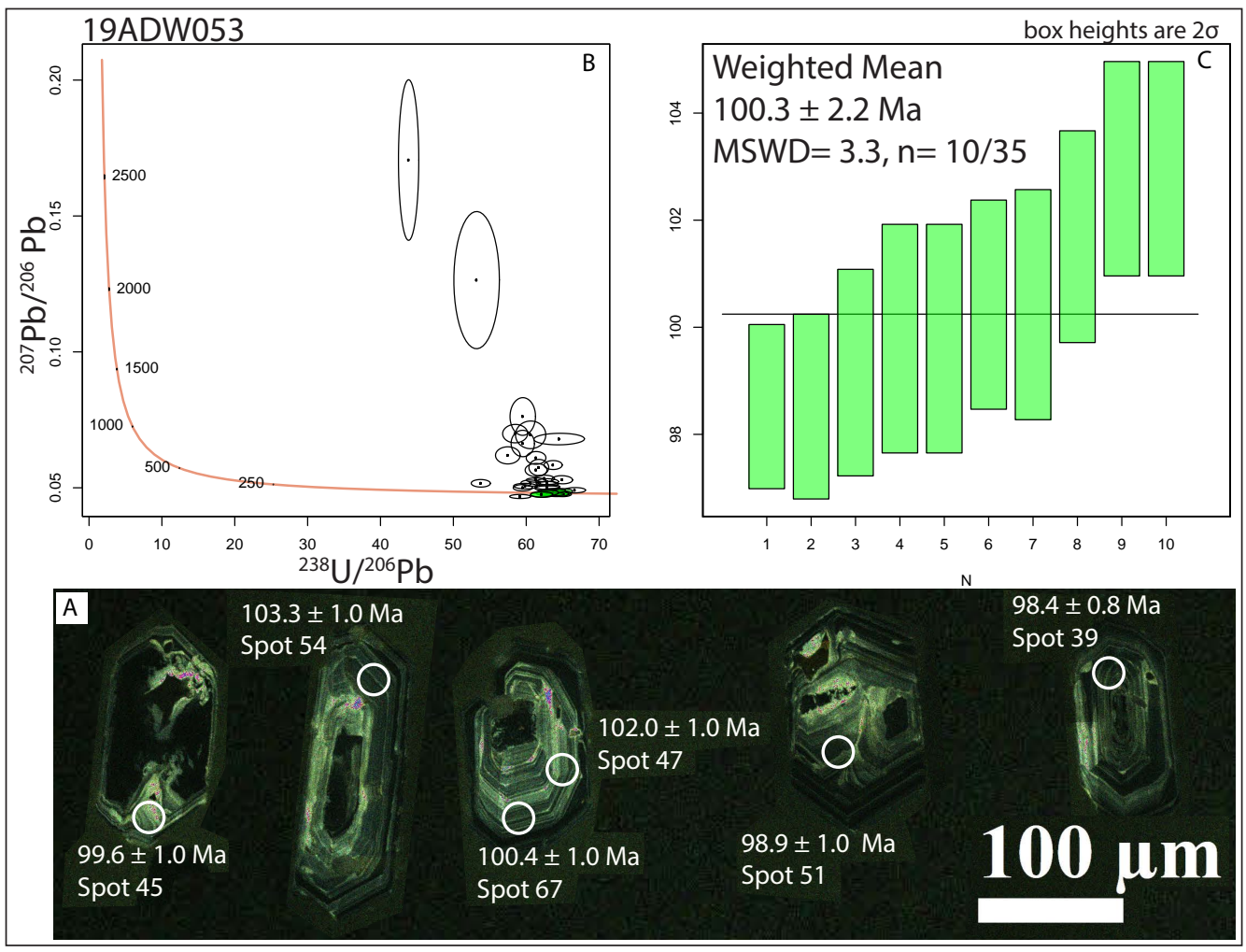

Figure 9. U-Pb data for sample 19ADW053. A. Cathodoluminescence images of representative zircon population with spot location and age. B. Tera-Wasserburg concordia diagram. C. Plot of ${ }^{206} \mathrm{~Pb} / 238 \mathrm{U}$ ages with weighted average of preferred ages. Ovals and bars indicate uncertainty at the 2-sigma level.

tion. Also contains 1 to $3 \mathrm{~mm}$ long, subhedral biotite, with hornblende inclusions and partial alteration to chlorite. Hornblende is overgrown by biotite. The sample is partially weathered and was taken from float.

Sample 19ET054 yielded a population of euhedral and elongated zircon crystals that range from 150-200 $\mu \mathrm{m}$ in length (fig. 10A). Primarily oscillatory and sector zonation in entirely igneous grains. Some core and rim evidence suggests igneous cores and a possible intermediate stage or partial reset, followed by continued oscillatory zonation. Cores can display irregular textures, convolute zoning, or are CL-dark.

\section{JEA029}

Granodiorite; black and white; weathering: light yellow gray; grain size: 1 to $6 \mathrm{~mm}$; mineralogy: 30 percent quartz, 30 percent plagioclase, 20 percent K-feldspar, five percent biotite, and one percent hornblende. Quartz phenocrysts are 1 to $2 \mathrm{~mm}$ and euhedral, and display undulose extinction, fractures, and occasional irregular, jagged crystal boundaries. Plagioclase is typically $1 \mathrm{~mm}$, euhedral, commonly zoned and twinned, and replaced partially by sericite, and contains inclusions of white mica. K-feldspar is $2 \mathrm{~mm}$, anhedral to euhedral, and interstitial, and displays tartan twins and exsolution lamellae. Biotite is typically $1 \mathrm{~mm}$ long, fresh, pleochroic, and show minor chlorite replacement. Hornblende is fine-grained, $0.25 \mathrm{~mm}$ in diameter with poorly defined cleavage. Sample is phaneritic, has chlorite and sericite alteration, and displays pervasive weathering. Sample taken from outcrop. 


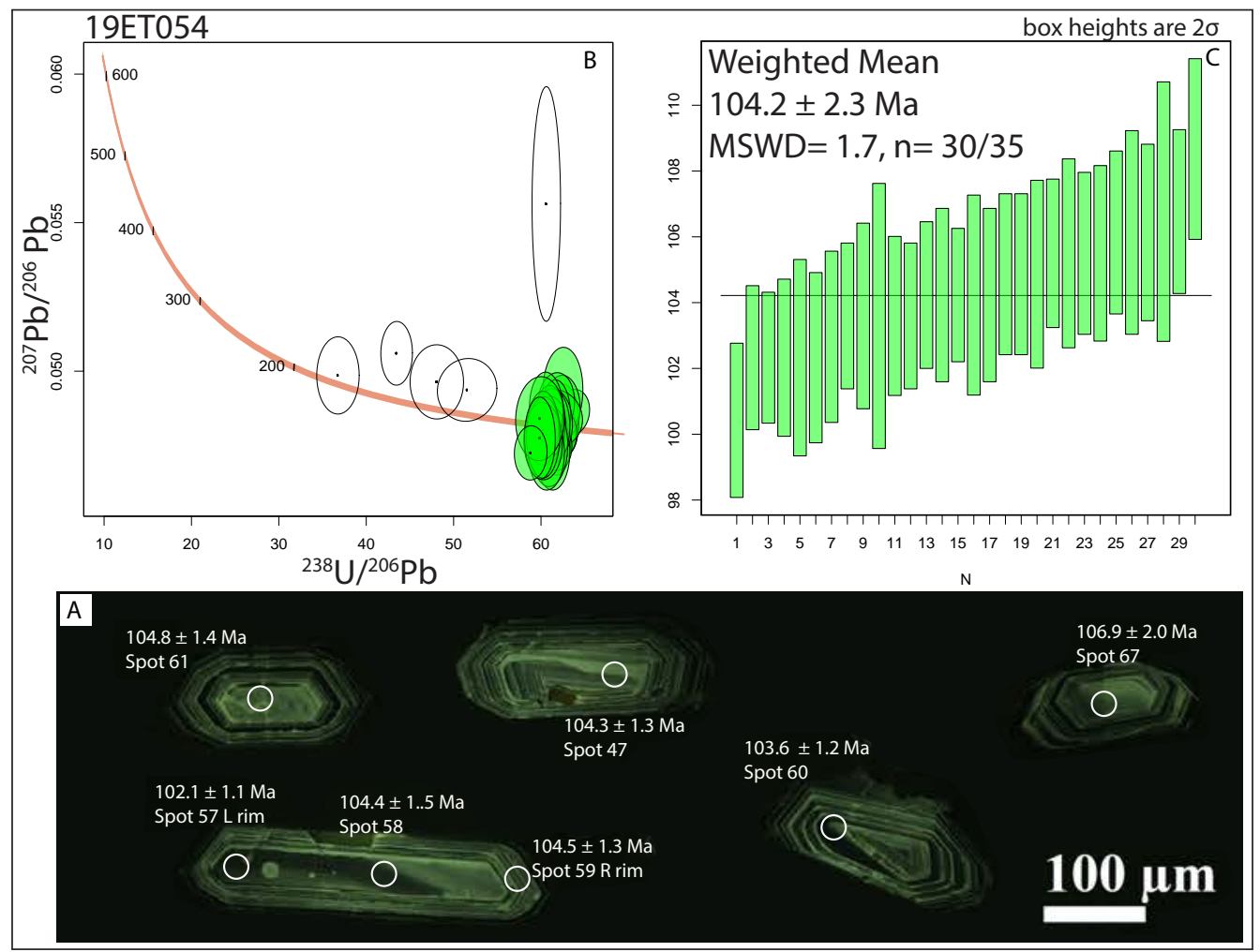

Figure 10. U-Pb data for sample 19ET054. A. Cathodoluminescence images of representative zircon population with spot location and age. B. Tera-Wasserburg concordia diagram. C. Plot of ${ }^{206} \mathrm{~Pb} / 238 \mathrm{U}$ ages with weighted average of preferred ages. Ovals and bars indicate uncertainty at the 2-sigma level.

Sample 19JEA029 yielded a population of subhedral and elongated zircon crystals ranging in length from 125-200 $\mu \mathrm{m}$. Internal textures of crystals are commonly metamict and convolute zonation with lesser lengthwise and oscillatory zoning. Igneous textures were targeted while picking analysis spots and CL-dark grains and metamict zones were avoided.

\section{ADW016}

Felsic hypabyssal intrusion, dark gray with purple tinge, porphyritic, grain size: 1 to $4 \mathrm{~mm}$; mineralogy: 20 percent feldspar, 15 percent hornblende, 15 percent quartz, 10 percent biotite, and 40 percent groundmass. Quartz is up to $3 \mathrm{~mm}$ in diameter; feldspar is largely sericitized. Some hornblende is skeletal and largely chloritized; biotite is completely chloritized. Fine-grained groundmass is composed of sericitized feldspar and quartz.

Sample 19ADW016 yielded a population of subhedral to euhedral, equant and lesser elongated zircon crystals ranging in length from 100-115 $\mu \mathrm{m}$ (fig. 11A). Internal textures of healthy crystals that were analyzed display oscillatory and sector zonation. A large portion of the population has metamict cores (50-60 percent) that were avoided during analysis. However, some of these metamict crystals had nice rims with oscillatory zonation that were large enough for a $20 \mu \mathrm{m}$ spot size. Some of these rims were CL-brighter than the rest of the crystal but were too narrow to analyze. 


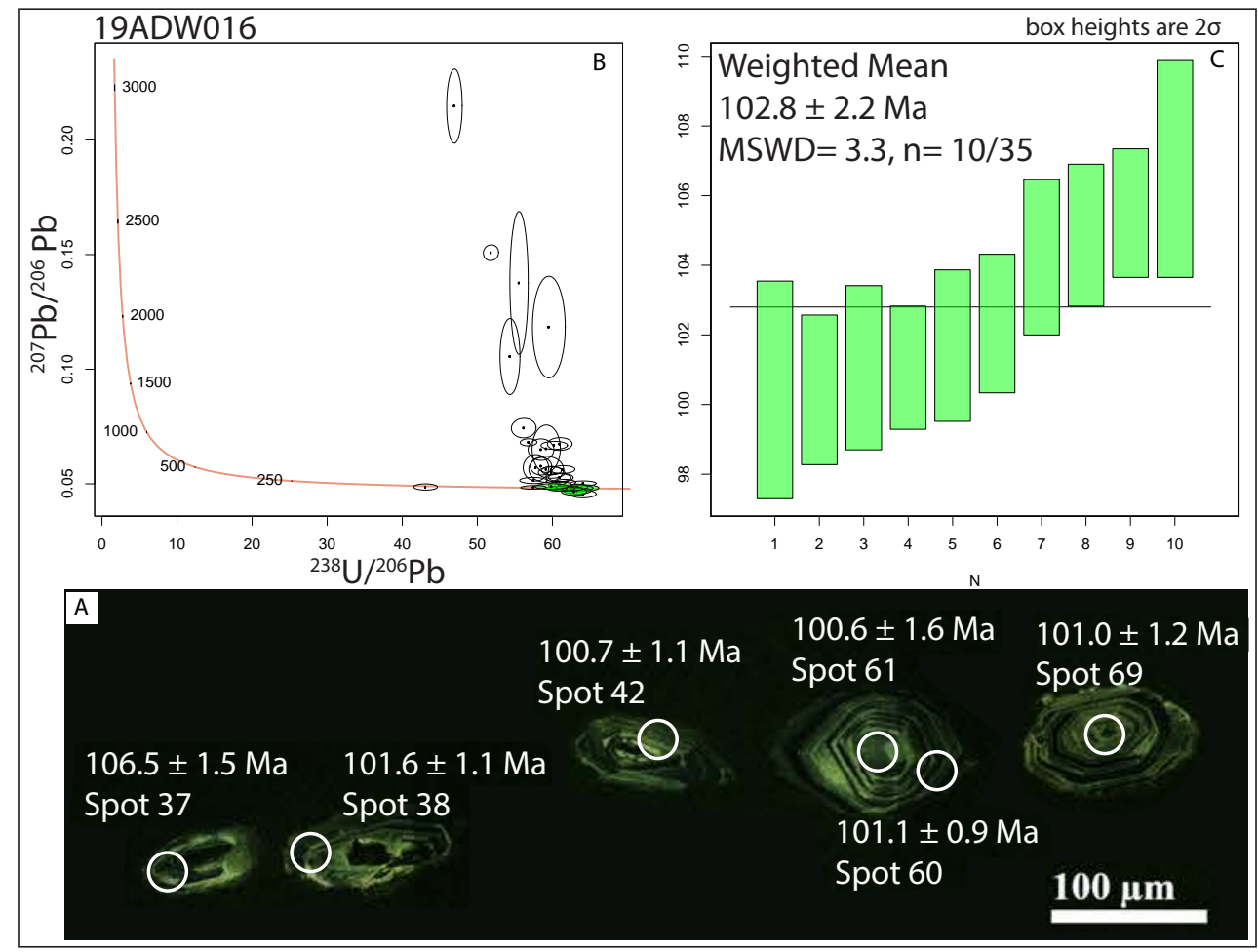

Figure 11. U-Pb data for sample 19ADW016. A. Cathodoluminescence images of representative zircon population with spot location and age. B. Tera-Wasserburg concordia diagram. C. Plot of ${ }^{206} \mathrm{~Pb} /{ }^{238} \mathrm{U}$ ages with weighted average of preferred ages. Ovals and bars indicate uncertainty at the 2-sigma level.

\section{$19 E T 102$}

Altered porphyry, Pushbush prospect; pale green-gray; porphyritic; grain size: 0.1 to $3 \mathrm{~mm}$; mineralogy: 15 percent feldspar (phenocrystic), 10 percent biotite (phenocrystic), 5 percent quartz (phenocrystic), allanite, and chlorite. Sericitized feldspars, chloritized biotite, and resorbed, subrounded quartz form phenocrysts in a very fine-grained matrix. Allanite is veined and brecciated. The rock contains disseminated sulfides, pyrite, and possible chalcopyrite, with sparse sub-millimeter quartz veinlets. Rock sample is partially weathered and altered. Alteration includes chloritization of mafic minerals (propylitic) overprinting possible potassic alteration. Sample taken from float.

Sample 19ET102 yielded a population of subhedral to euhedral, elongated and lesser equant zircon crystals with long axes ranging in size from approximately $200-225 \mu \mathrm{m}$, but up to $300 \mu \mathrm{m}$. Internal textures included primarily oscillatory, lengthwise, and sector zonation, with a subpopulation of zircon crystals with cores and rims. The cores of these crystals can be somewhat fractured and metamict. A few crystals have fractures or missing parts; otherwise, the majority are intact.

\section{$19 E T 288$}

Granite; sheared, protomylonitic; light tan; equigranular; grain size: 2 to $5 \mathrm{~mm}$; mineralogy: K-feldspar, plagioclase, 25 percent quartz (glomerocrysts), one percent biotite, and secondary chlorite. Contains 3 to $5 \mathrm{~mm}$ primary grains are replaced by aggregates of 0.2 to $1 \mathrm{~mm}$ granoblastic quartz and 2 to $5 \mathrm{~mm}$, interlocking K-feldspar crystals with quartz and plagioclase and slightly undulose extinction. Also contains 
1 to $4 \mathrm{~mm}$ interlocking plagioclase with twins kinked by shearing and $1 \mathrm{~mm}$ biotite books almost entirely replaced by chlorite. The rock is cut by 0.2 to $5 \mathrm{~mm}$ bands that display grainsize reduction: the majority of grains are reduced to $20-50 \mu \mathrm{m}$, with some larger, $0.5-1 \mathrm{~mm}$ grains. Sample was partially weathered and collected from an outcrop.

Sample 19ET288 yielded a population of euhedral and elongated, with lesser equant, zircon crystals with long axes ranging from 100-125 $\mu \mathrm{m}$ (fig. 12A). Internal textures are dominantly oscillatory and lesser lengthwise zonation with evidence of minor recrystallized or newly grown domains, which show irregular textures closer to the cores. Fractures present but not pervasive.

\section{$19 E T 146$}

Granite pluton; weakly strained; light pink; massive; equigranular; grain size: 2 to $5 \mathrm{~mm}$; mineralogy: 50 percent K-feldspar, 30 percent quartz, 15 percent plagioclase, one percent biotite, two percent sericite, and 0.1 percent chlorite. Contains 2 to $5 \mathrm{~mm} \mathrm{~K}$-feldspar with single twinning (suggesting oligoclase), 1 to $4 \mathrm{~mm}$ in diameter, and subhedral, slightly resorbed quartz. The plagioclase and 1 to $2 \mathrm{~mm}$ biotite books comprise most of the rock. The plagioclase is sericitized and the biotite is weakly chloritized. Sample taken from outcrop.

Sample 19ET146 yielded a population of subhedral to euhedral and mostly equant zircon crystals with lengths between 100-150 $\mu \mathrm{m}$ (fig. 13A). Internal texture is primarily oscillatory zonation. Inherited cores and fractures are limited.

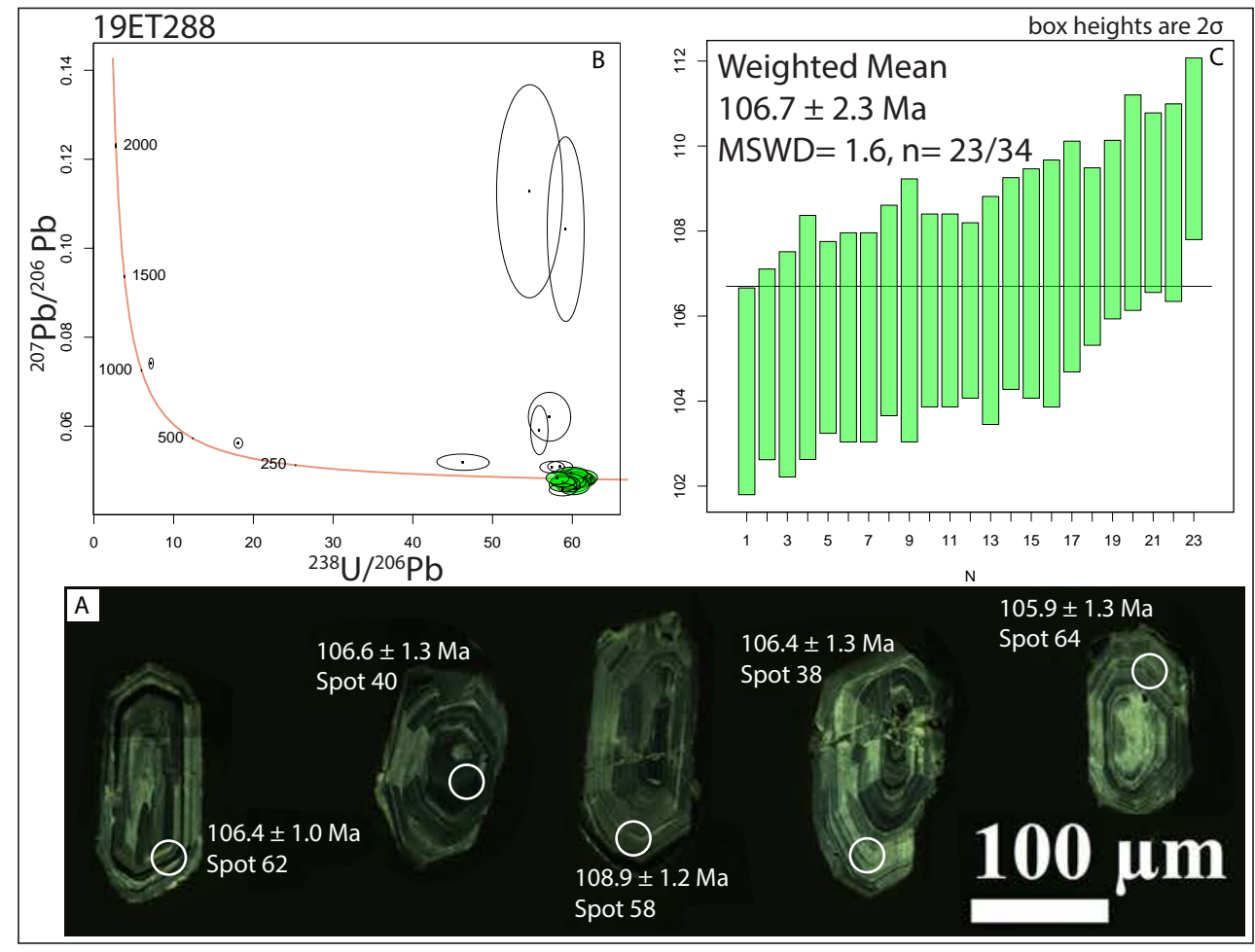

Figure 12. U-Pb data for sample 19ET288. A. Cathodoluminescence images of representative zircon population with spot location and age. B. Tera-Wasserburg concordia diagram. C. Plot of ${ }^{206} \mathrm{~Pb} /{ }^{238} \mathrm{U}$ ages with weighted average of preferred ages. Ovals and bars indicate uncertainty at the 2-sigma level. 


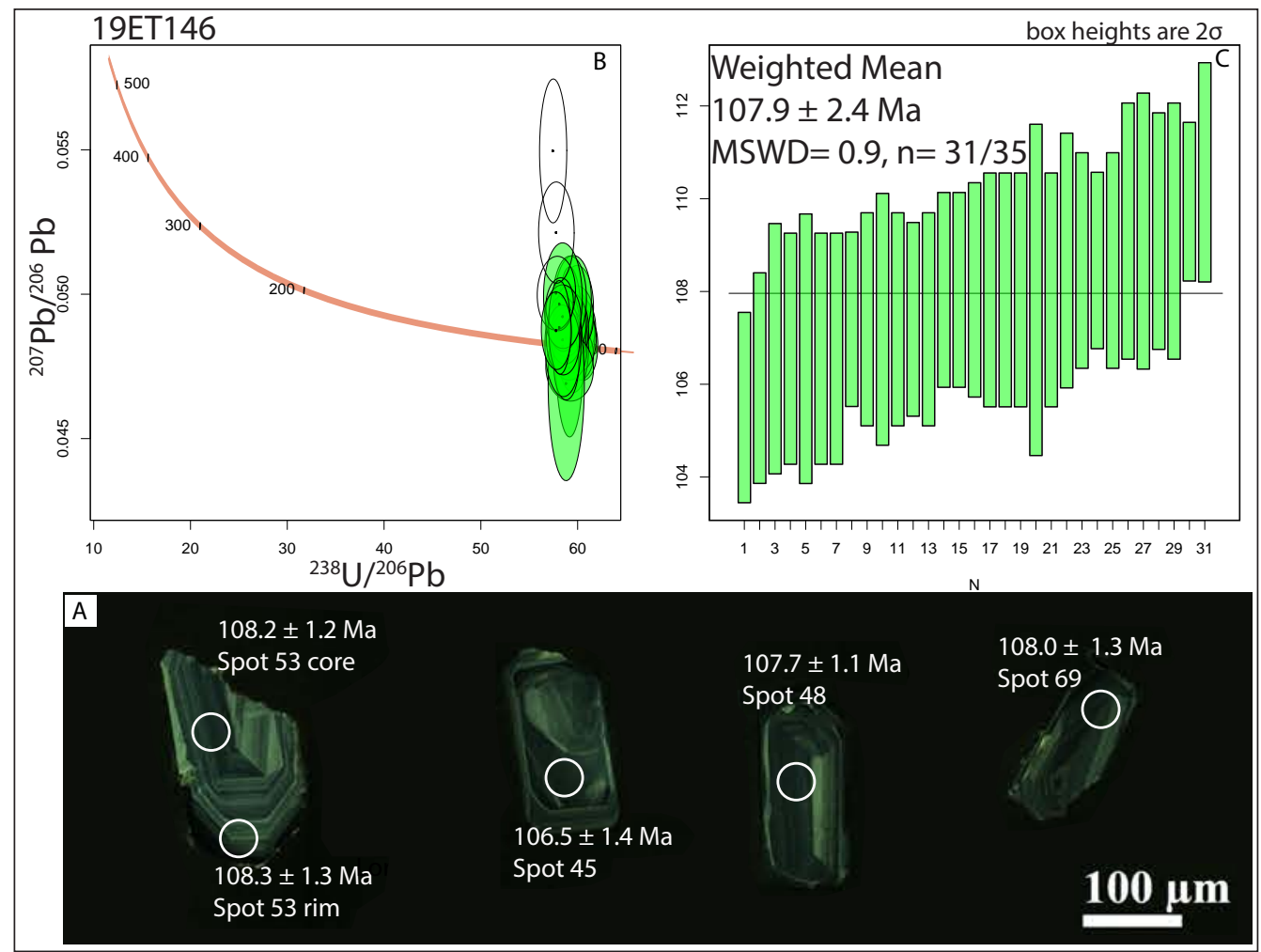

Figure 13. U-Pb data for sample 19ET146. A. Cathodoluminescence images of representative zircon population with spot location and age. B. Tera-Wasserburg concordia diagram. C. Plot of ${ }^{206} \mathrm{~Pb} /{ }^{238} \mathrm{U}$ ages with weighted average of preferred ages. Ovals and bars indicate uncertainty at the 2-sigma level.

\section{WCW039}

Granite; pink, gray; fine- to medium-grained, equigranular; grain size: 0.5 to $3 \mathrm{~mm}$. Mineralogy: 50 percent K-feldspar (1 to $3 \mathrm{~mm}$, subhedral, untwinned), 30 percent quartz (subhedral [early?] grains, 1 to 2 $\mathrm{mm}$, slight undulose extinction), 10 percent plagioclase (1 to $2 \mathrm{~mm}$ twinned grains, partially sericitized), 1 percent biotite (1 to $2 \mathrm{~mm}$, almost completely replaced by white mica, opaques, and a little chlorite. Some white mica could be primary magmatic), 0.1 percent white mica (possible primary magmatic white mica, abundant opaques suggest it could be altered biotite), trace tourmaline. Trace weathering was observed in the sample and it was collected from subcrop.

Sample 19WCW039 yielded a population of equant to primarily elongated euhedral, and lesser equant, zircon grains with average length ranging from 100-200 $\mu \mathrm{m}$ (fig. 32). Internal textures observed are straight, sector, and oscillatory zonation, with the occasional metamict crystal (damaged core) avoided during analysis. Zircon crystals display minimal fractures.

\section{TJN181}

Granite intrusion; pink; fine-grained aplitic; grain size: 0.1 to $6 \mathrm{~mm}$. Mineralogy: 50 percent feldspar (1-3 mm, partly sericitized, interstitial to quartz phenocrysts), 45 percent quartz (up to $3 \mathrm{~mm}$, 20 percent quartz as phenocrysts up to $4 \mathrm{~mm}, 25$ percent as interstitial quartz along with feldspar), and 5 percent biotite (1-2 mm long phenocrysts, partly resorbed and partly chloritized.) Sample is unweathered and found as subcrop. 


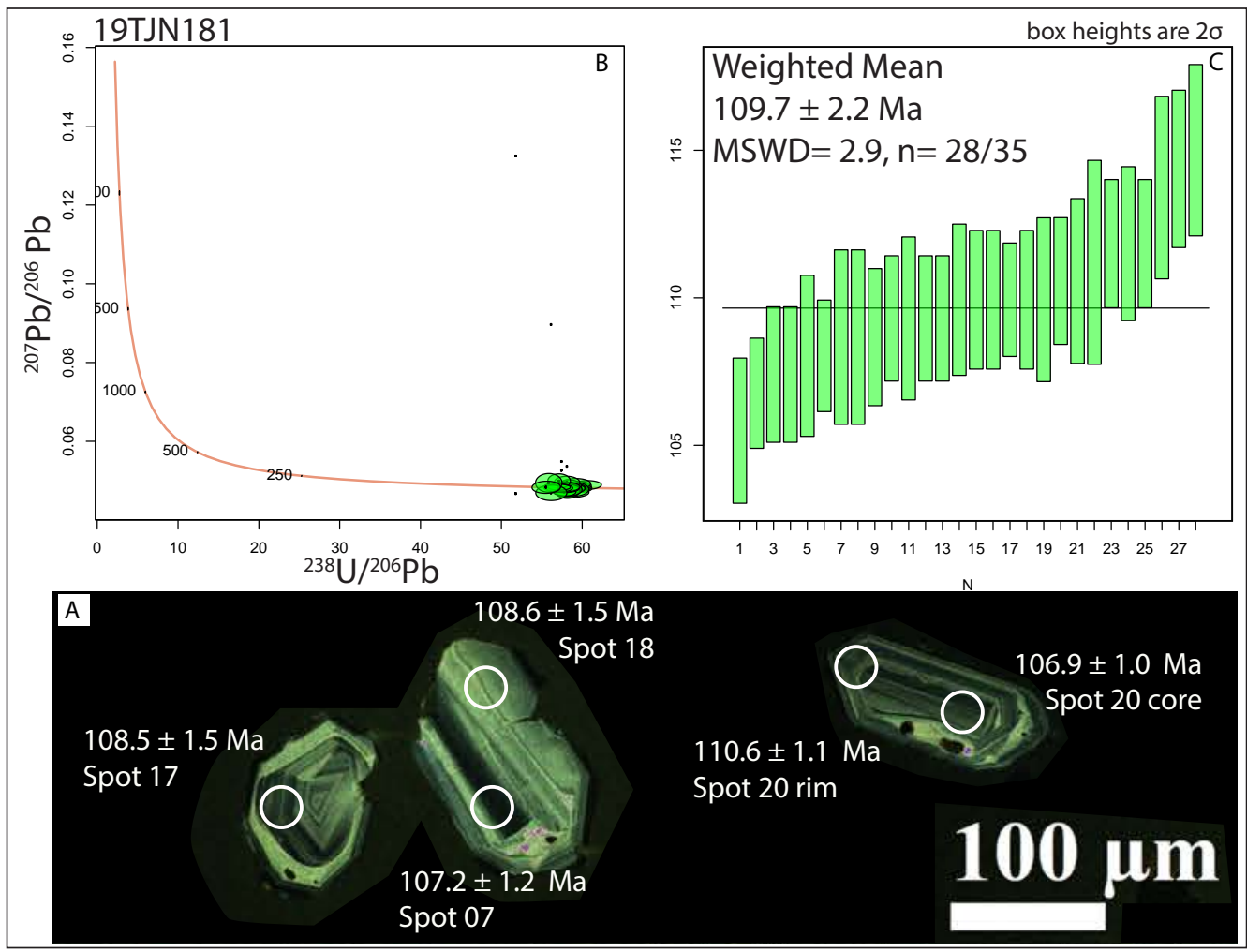

Figure 14. U-Pb data for sample 19TJN181. A. Cathodoluminescence images of representative zircon population with spot location and age. B. Tera-Wasserburg concordia diagram. C. Plot of ${ }^{206} \mathrm{~Pb} / 238 \mathrm{U}$ ages with weighted average of preferred ages. Ovals and bars indicate uncertainty at the 2-sigma level.

Sample 19TJN181 yielded a population of somewhat equant, anhedral to subhedral, zircon crystals with long axes varying in length between $50-150 \mu \mathrm{m}$ (fig. 14A). A variety of internal textures are noted such as sector, oscillatory, and lengthwise zonation. Fractures are present and crystals are often broken. Inclusions in the cores of the crystals are common. CL-dark grains were avoided during analysis due to probable damage caused by metamictisation.

\section{RN423}

Biotite-bearing granite; gray; jointed; equigranular; grain size: 1 to $4 \mathrm{~mm}$; mineralogy: 27 percent feldspar, 30 percent quartz, 25 percent K-feldspar, 15 percent biotite (phenocrystic), and three percent magnetite. The K-feldspars are typically 1 to $4 \mathrm{~mm}$ long, whereas other feldspar grains are finer-grained and range between 0.5 to $1.5 \mathrm{~mm}$. The biotite is up to 25 percent chloritized and contains small inclusions of rutile. Sample has weak alteration, is partially weathered, and was collected from subcrop.

Sample 19RN423 yielded a population of subhedral to euhedral, somewhat elongated, zircon crystals. The long axes of the crystals vary in length from 100-150 $\mu \mathrm{m}$ (fig. 15A). Primary internal textures are sector zonation, oscillatory zonation, and core and rims. Several grains display CL-dark zones coinciding with metamict and damaged cores. 


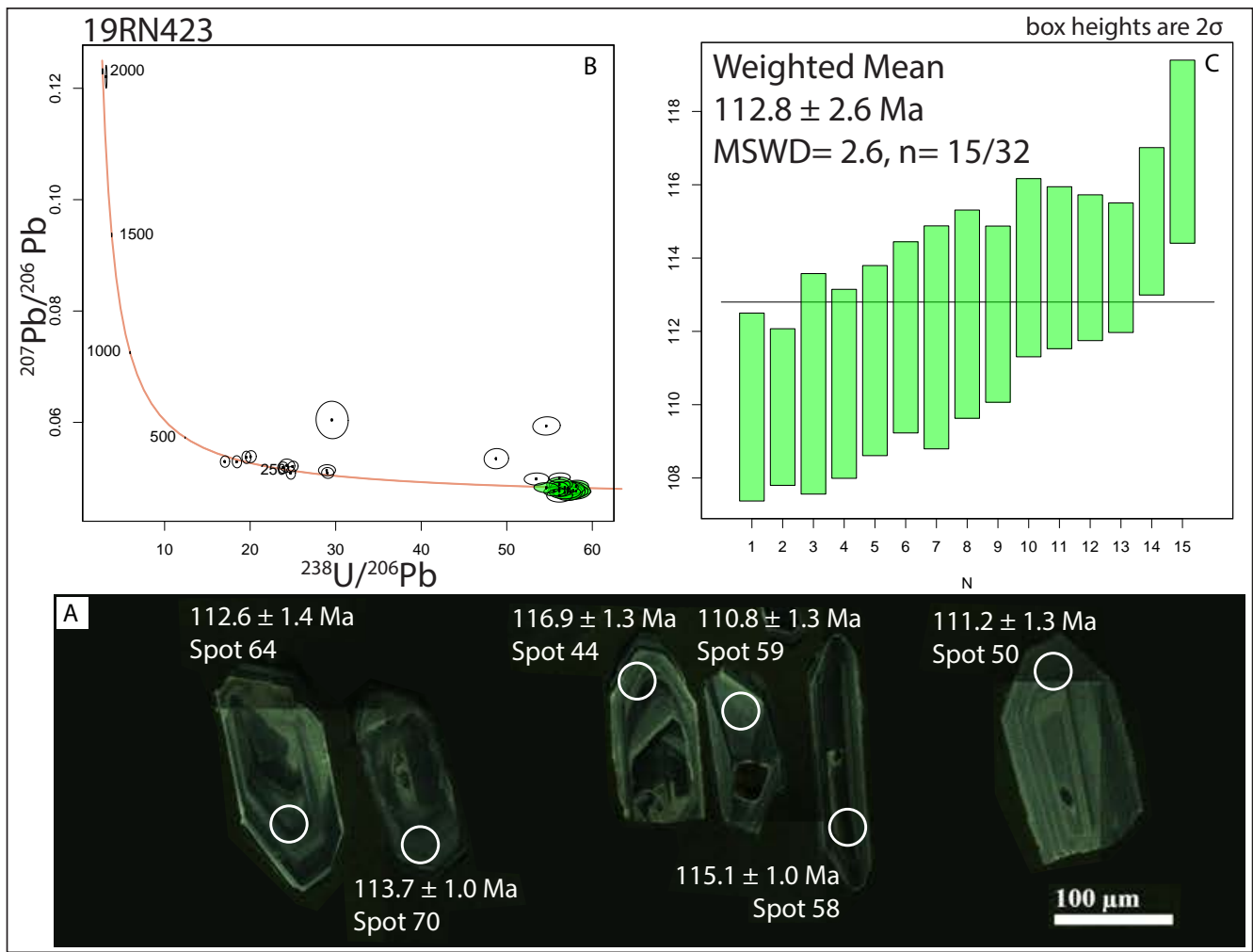

Figure 15. U-Pb data for sample 19RN423. A. Cathodoluminescence images of representative zircon population with spot location and age. B. Tera-Wasserburg concordia diagram. C. Plot of ${ }^{206} \mathrm{~Pb} /{ }^{238} \mathrm{U}$ ages with weighted average of preferred ages. Ovals and bars indicate uncertainty at the 2-sigma level.

\section{AW200}

Porphyry with granite composition; gray, pale pink to creamy; glomeroporphyritic; grain size: 0.01 to $7 \mathrm{~mm}$; mineralogy: five percent feldspar, two percent quartz, and two percent biotite. Weathering: trace. Large, up to $7 \mathrm{~mm}$, subhedral quartz; up to $5 \mathrm{~mm}$, sub- to euhedral feldspar; and $4 \mathrm{~mm}$, sub- to euhedral biotite phenocrysts in an aphanitic, pale gray matrix. The feldspars are fresh, often clustered, and forming glomerocrysts, whereas the biotite is chloritized. Sample taken from outcrop.

Sample 19AW200 yielded a population of euhedral and elongated, lesser equant, zircon crystals with long axes ranging in length between 150-200 $\mu \mathrm{m}$ (fig.16A). Internal textures of the zircon crystals were primarily igneous and display oscillatory and sector zonation. Several grains show inherited core and igneous rim textures.

\section{RN222}

Altered dike of intermediate composition; pale gray-green; massive; aphanitic; porphyritic; grain size: 0.01 to $8 \mathrm{~mm}$; mineralogy: 35 percent plagioclase, 20 percent quartz, 10 percent biotite, and 10 percent hornblende. Plagioclase is 1 to $8 \mathrm{~mm}$ long and replaced by sericite. Quartz is 0.5 to $2 \mathrm{~mm}$. The biotite and hornblende are both mostly replaced by chlorite and epidote. Phenocrysts are in an aphanitic groundmass. Sample was collected from a frost boil and is weakly altered and partially weathered.

Sample 19RN222 yielded a population of subhedral to euhedral, elongated zircon crystals with long axes typically $150 \mu \mathrm{m}$ in length (fig. 17A). Internal textures consist of oscillatory zonation with inherited cores common. A few crystals are metamict with convolute zonation and were avoided during analysis. 


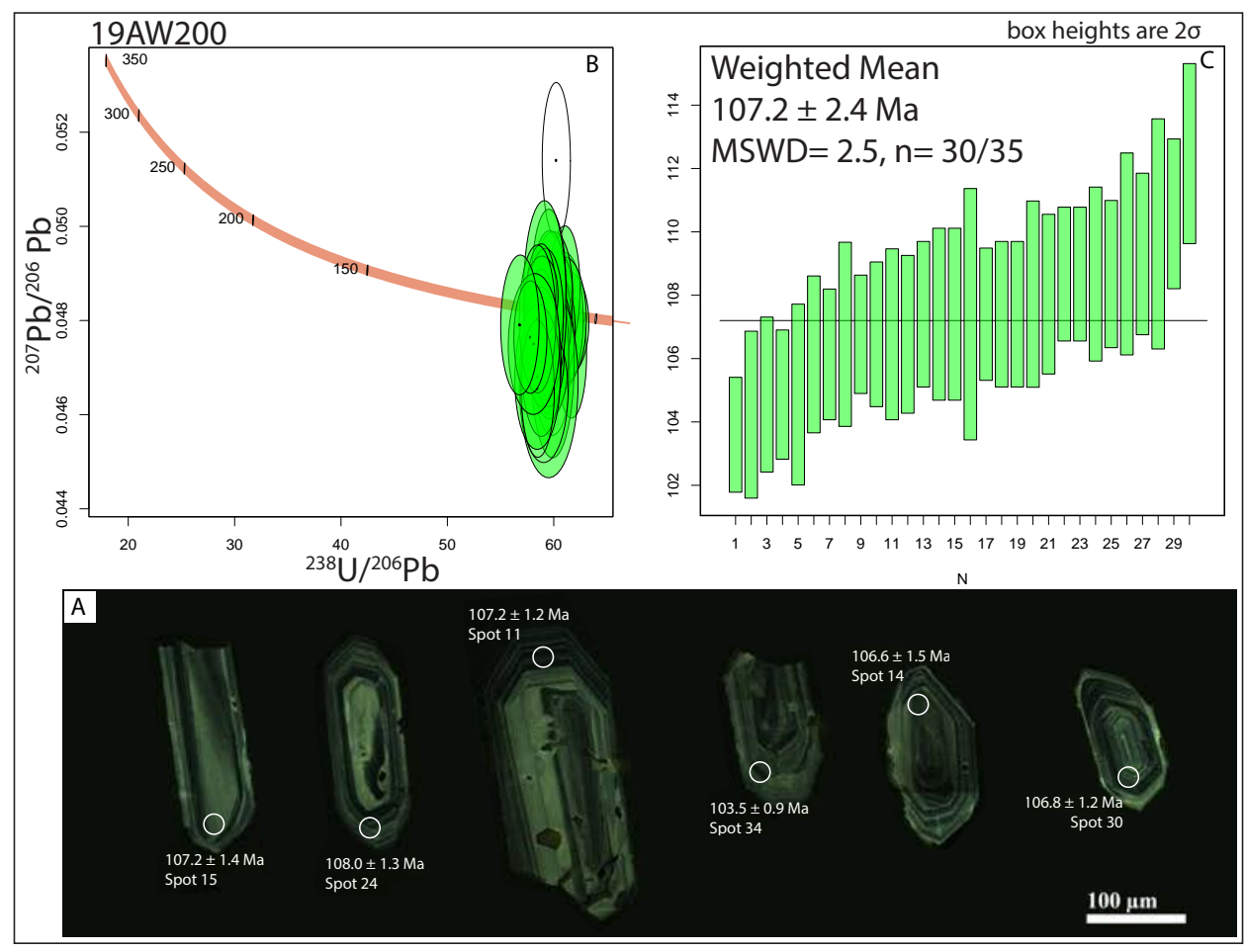

Figure 16. U-Pb data for sample 19AW200. A. Cathodoluminescence images of representative zircon population with spot location and age. B. Tera-Wasserburg concordia diagram. C. Plot of ${ }^{206} \mathrm{~Pb} / 238 \mathrm{U}$ ages with weighted average of preferred ages. Ovals and bars indicate uncertainty at the 2-sigma level.

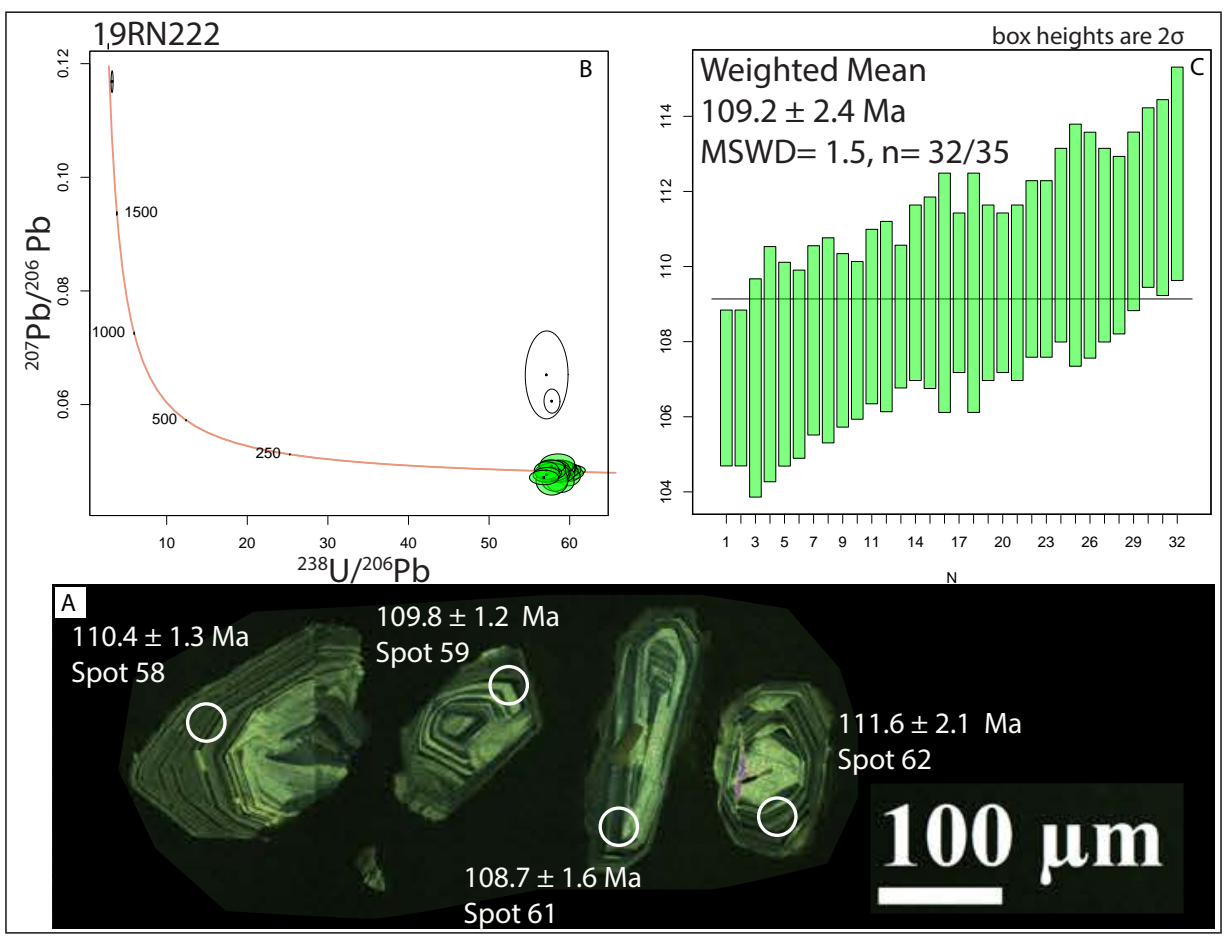

Figure 17. U-Pb data for sample 19RN222. A. Cathodoluminescence images of representative zircon population with spot location and age. B. Tera-Wasserburg concordia diagram. C. Plot of ${ }^{206} \mathrm{~Pb} / 238 \mathrm{U}$ ages with weighted average of preferred ages. Ovals and bars indicate uncertainty at the 2-sigma level. 


\section{TJN231}

Granite; aplitic; mineralogy: 50 percent quartz, 50 percent feldspar (largely sericitized), white mica (trace), biotite (questionable), and oxides (as inclusions in white mica). Trace weathering was observed in the sample, and it was collected from float. Aplitic granite is most abundant at this location and was sampled. Porphyritic granite with phenocrysts up to $12 \mathrm{~mm}$ was also present at the field site, similar to previous stations. No context about field relations.

Sample 19TJN231 yielded a population of subhedral, equant to elongated zircon crystals with long axes ranging from 100-125 $\mu \mathrm{m}$ (fig. 18A). Primary internal textures included oscillatory and sector zonation, with some evidence of core and rims. Crystals are often broken and/or fractured. CL-dark grains were interpreted as metamict and avoided during analysis.

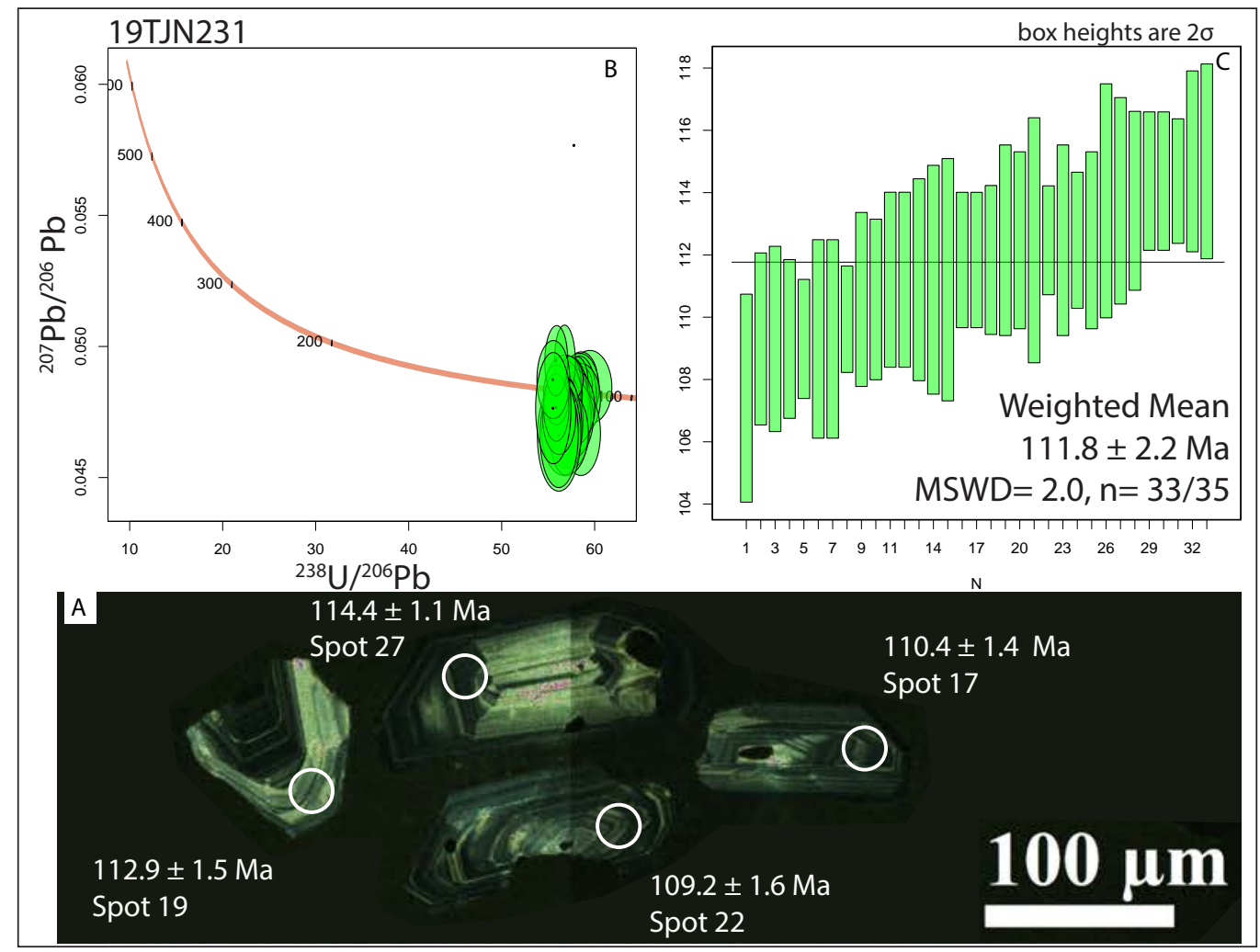

Figure 18. U-Pb data for sample 19TJN231. A. Cathodoluminescence images of representative zircon population with spot location and age. B. Tera-Wasserburg concordia diagram. C. Plot of ${ }^{206} \mathrm{~Pb} / 238 \mathrm{U}$ ages with weighted average of preferred ages. Ovals and bars indicate uncertainty at the 2-sigma level.

\section{SPR 102}

Granite; porphyry intrusion with 3 percent K-feldspar, 2-3 percent plagioclase, 2 percent quartz, less than 1 percent oxides, and up to 90 percent fine-grained groundmass of intergrown quartz-feldspar (granophyric), with average groundmass size ranging from 0.1-0.2 mm. K-feldspar phenocrysts are large, sub- to euhedral, typically 1-2.5 mm but up to $4 \mathrm{~mm}$, and sericitized, with simple twins common and lesser tartan twinning. Plagioclase phenocrysts are typically $2 \mathrm{~mm}$ up to 3-4 $\mathrm{mm}$ in size and sub- to euhedral, with inclusions of white mica and polysynthetic twinning. Quartz phenocrysts range in size from 1.5 to 
$2 \mathrm{~mm}$. Quartz grains are sub- to euhedral with straight boundaries and contain many 0.25 to $0.5 \mathrm{~mm}$ inclusions of feldspar and white mica. Quartz boundaries could have experienced resorption or just growth around fine groundmass. Contains 1 to $2 \mathrm{~mm}$ wide quartz veinlets running through the thin section. Sample was collected from float.

Sample 19SPR102 yielded a population of anhedral to subhedral, equant zircon crystals that are typically 50-100 $\mu \mathrm{m}$ long (fig. 19A). Internal textures include primarily sectoral and convolute zonation, which is typically different and/or more complicated than the other mid-Cretaceous samples analyzed. CLdark crystals ( $\sim 30$ percent) were interpreted to be metamict and avoided during analysis. Fractures and broken crystals are also common throughout the sample population.

\section{TJN299}

Tuffaceous dacite; gray; grain size: $3 \mathrm{~mm}$; mineralogy: 17 percent feldspar (phenocrystic), 8 percent quartz (phenocrystic), and fine-grained groundmass. Crystal-rich tuff with 25 to 30 percent broken phenocrysts and devitrifying groundmass. Sample was observed to have trace weathering and was taken from outcrop.

Sample 19TJN299 yielded a population of subhedral to euhedral and elongated zircon crystals ranging in length from 150-200 $\mu \mathrm{m}$ (fig. 20A). Internal textures: primarily magmatic crystals display oscillatory and lesser sector zonation. Occasional zircon crystal displays igneous core-rim textures, while others have experienced some degree of dissolution and are missing parts. Nearly 50 percent of the population are CL-dark and were avoided during analysis.

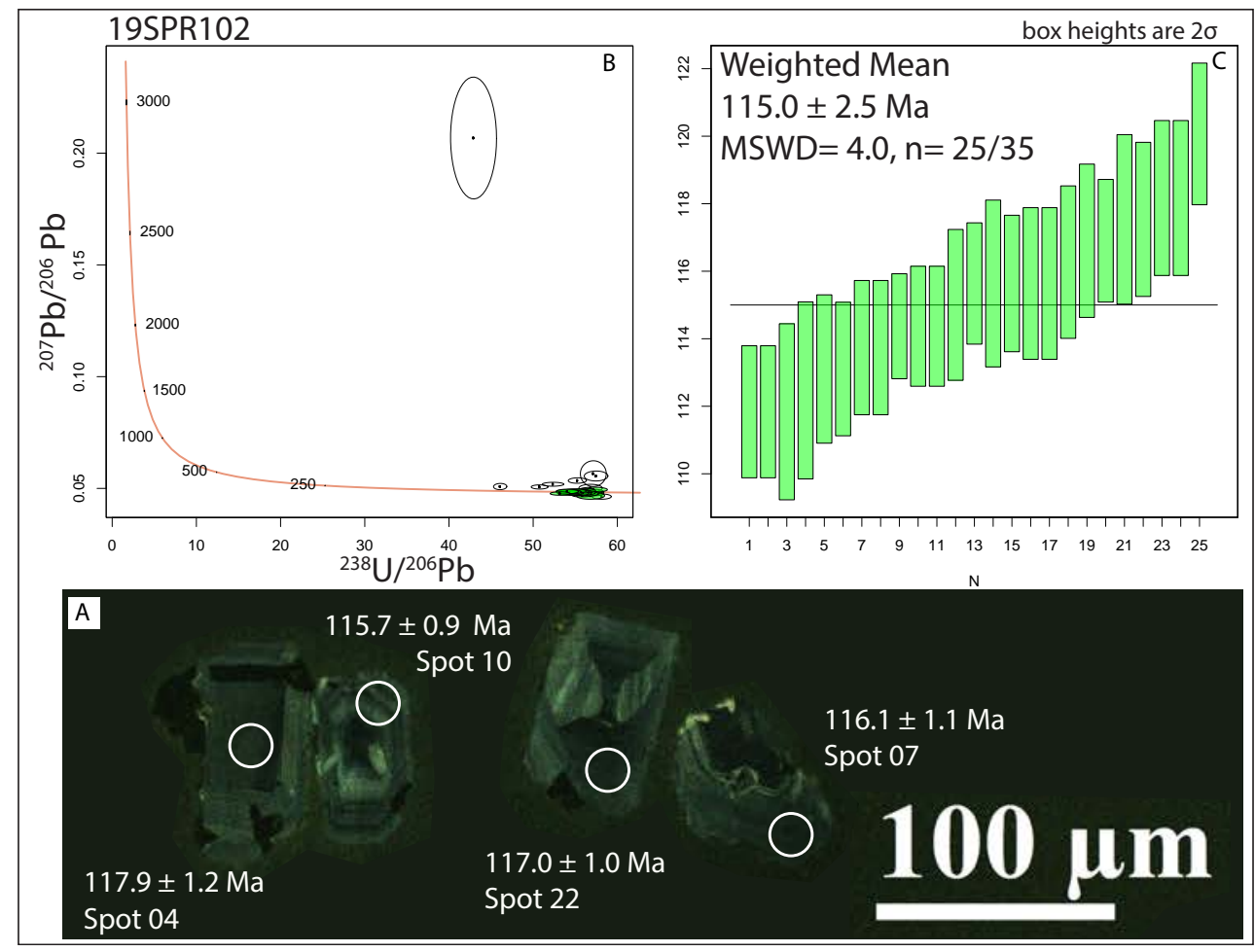

Figure 19. U-Pb data for sample 19SPR102. A. Cathodoluminescence images of representative zircon population with spot location and age. B. Tera-Wasserburg concordia diagram. C. Plot of ${ }^{206} \mathrm{~Pb} / 238 \mathrm{U}$ ages with weighted average of preferred ages. Ovals and bars indicate uncertainty at the 2-sigma level. 


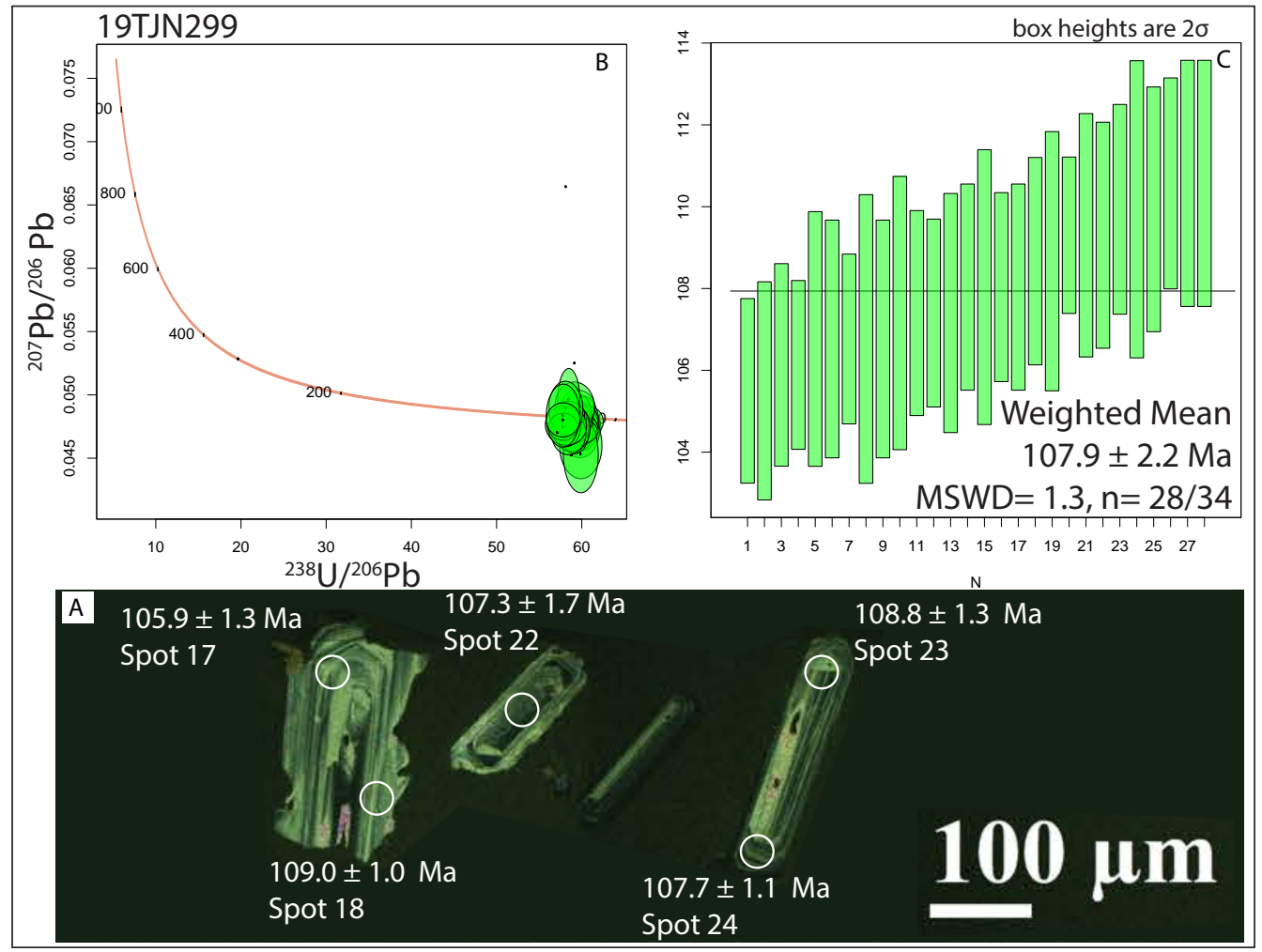

Figure 20. U-Pb data for sample 19TJN299. A. Cathodoluminescence images of representative zircon population with spot location and age. B. Tera-Wasserburg concordia diagram. C. Plot of ${ }^{206} \mathrm{~Pb} /{ }^{238} \mathrm{U}$ ages with weighted average of preferred ages. Ovals and bars indicate uncertainty at the 2-sigma level.

\section{SPR027}

Hornblende-rich diorite; rock type: intrusive diorite; grain size: 3 to $8 \mathrm{~mm}$; mineralogy: 55 percent plagioclase, 35 percent hornblende, five percent quartz, two percent sericite, one percent actinolite, one percent biotite, and possibly one percent K-feldspar. Plagioclase is 0.5 to $1 \mathrm{~mm}$, occasionally zoned, and weakly replaced by sericite. Hornblende grains are 1 to $4 \mathrm{~mm}$ long and euhedral to anhedral, with brownlight brown pleochroism. Quartz grains are typically $1 \mathrm{~mm}$ in diameter and are interstitial. Actinolite, biotite, and sericite are secondary after hornblende and plagioclase.

Sample 19SPR027 yielded a population of elongated and anhedral to subhedral zircon grains with typical lengths from $75-100 \mu \mathrm{m}$ and up to $250-300 \mu \mathrm{m}$ (fig. 21A). Straight and sector zonation, fractures, and missing parts common throughout zircon crystals. CL-dark grains (30-40 percent of population) were interpreted to be damaged by metamictisation and were avoided during analysis. Some grains have CL-brighter domains near the cores and along rims that were too small to be analyzed.

\section{Allochthonous rocks of the Klondike Assemblage $19 E T 098$}

Metarhyolite; pink tan; mylonitic; grain size: 0.05 to $0.2 \mathrm{~mm}$; mineralogy: quartz, feldspar, white mica, and opaque minerals. Sample contains very fine bands of fine-grained matrix with about 5 percent, up to 2 $\mathrm{mm}$ long, highly included, broken up, and resorbed feldspar porphyroclasts. Selected feldspar porphyroclasts have shadow tails formed by up to $0.5 \mathrm{~mm}$ quartz and $0.1 \mathrm{~mm}$ white mica. Sample taken from float. 


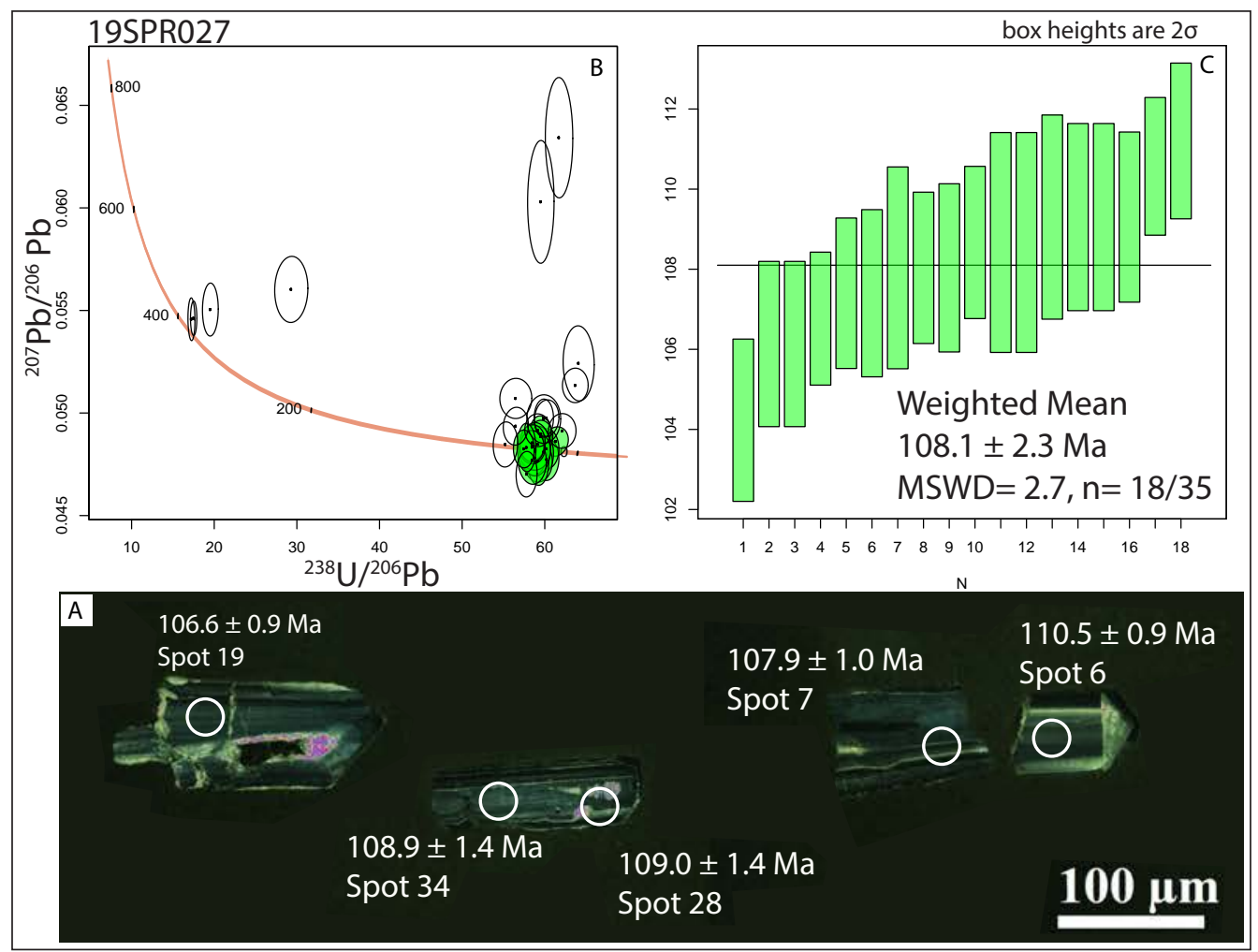

Figure 21. U-Pb data for sample 19SPR027. A. Cathodoluminescence images of representative zircon population with spot location and age. B. Tera-Wasserburg concordia diagram. C. Plot of ${ }^{206} \mathrm{~Pb} /{ }^{238} \mathrm{U}$ ages with weighted average of preferred ages. Ovals and bars indicate uncertainty at the 2-sigma level.

Sample 19ET098 yielded a population of equant and subhedral to euhedral zircon crystals that range in length from $50-100 \mu \mathrm{m}$ (fig. 22A). Internal texture is primarily oscillatory zonation. CL-dark grains were interpreted to be metamict and were avoided during analysis. Inherited cores are observed but not abundant. Crystals have limited fractures, and edges are typically smooth and rounded.

\section{$19 E T 126$}

Quartz-augen metarhyolite; greenschist-facies mineralogy; light tan; schistose; grain size: 0.1 to 4 $\mathrm{mm}$; mineralogy: five percent white mica, three percent quartz, three percent epidote, and two percent plagioclase. Up to $2 \mathrm{~mm}$ long porphyroclasts of quartz and plagioclase in fine-grained matrix with white mica and epidote. The quartz is rotated, forms quartz eyes, and shows evidence of recrystallization with subgrains. Plagioclase displays albite twinning, inclusions of white mica, and recrystallization at tails. Moderate foliation defined by white mica. Weathering is pervasive. Sample taken from float.

Sample 19ET126 yielded a population of elongated and lesser equant, anhedral to subhedral zircon grains with lengths ranging from 100-150 $\mu \mathrm{m}$ (see fig. 33). Oscillatory and straight zonation are the primary internal textures. Fractures approximately $10-15 \mu \mathrm{m}$ wide are observed crossing the width of several crystals. Inherited cores are present but not abundant, and CL-dark grains were avoided because of potential for metamictisation. 


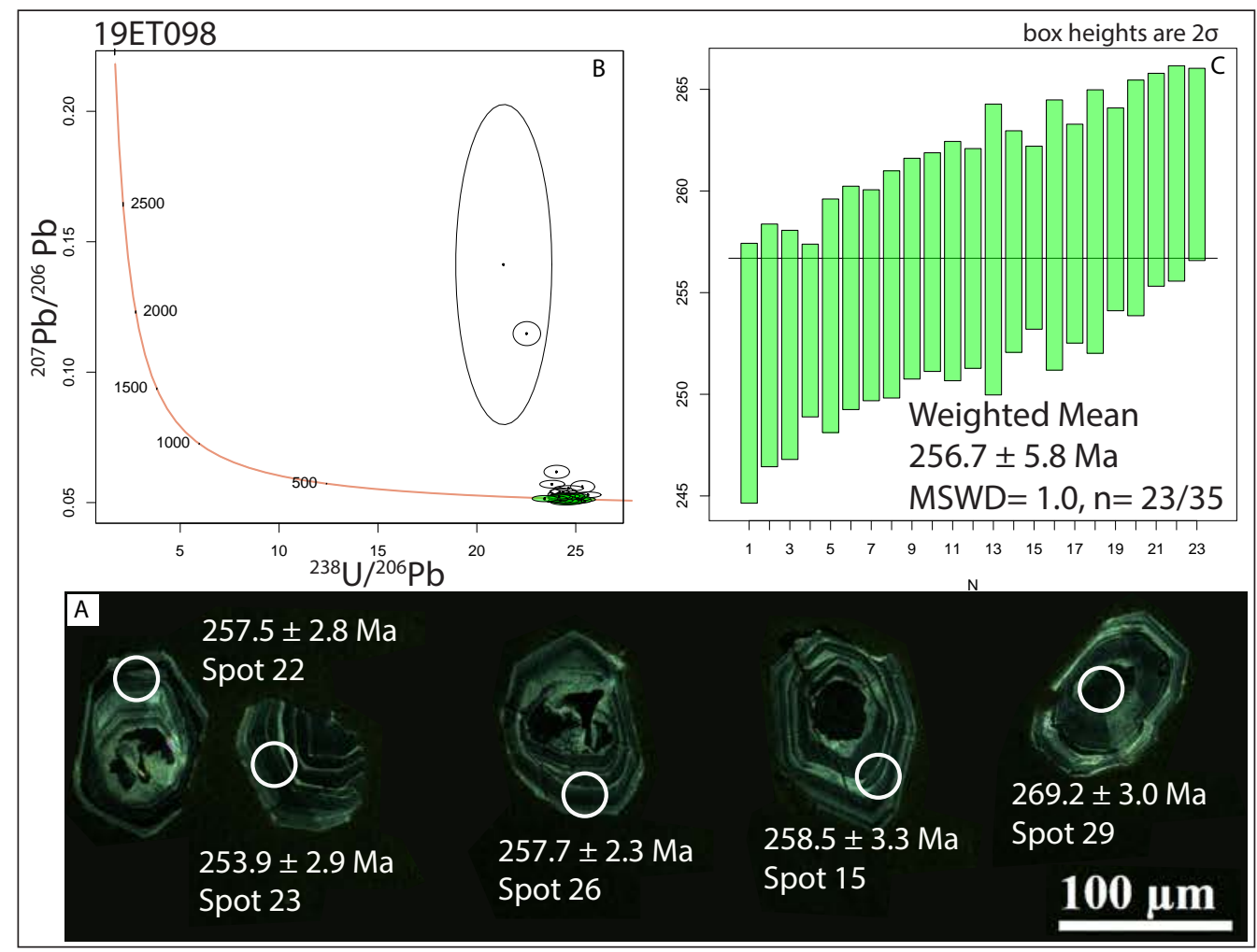

Figure 22. U-Pb data for sample 19ET098. A. Cathodoluminescence images of representative zircon population with spot location and age. B. Tera-Wasserburg concordia diagram. C. Plot of ${ }^{206} \mathrm{~Pb} / 238 \mathrm{U}$ ages with weighted average of preferred ages. Ovals and bars indicate uncertainty at the 2-sigma level.

\section{Allochthonous Rocks of the Ladue River Unit 19 WCW048}

Feldspar-porphyroclastic metagranitoid; gray, white; foliated; grain size: 0.5 to $3 \mathrm{~mm}$; mineralogy: 60 percent quartz (granoblastic quartz aggregates), 25 percent muscovite (aligned in foliation), 10 percent plagioclase (some twins, partial sericite replacement), and 5 percent biotite (partially altered to chlorite and oxides). Trace weathering is observed in the sample.

Sample 19WCW048 yielded a population of equant to elongated, subhedral zircon crystals. The long axes range in length from approximately 25-100 $\mu \mathrm{m}$. Internal textures are primarily oscillatory with lesser patchy and sector zonation. Many crystals display fractures, while others are clearly broken and have been reduced in size.

\section{$19 E T 158$}

Coarse-grained amphibolite with early coarse hornblende showing overprint of actinolite-albite-clinozoisite. Mineralogy: 40 percent hornblende, 35 percent actinolite, 10 percent epidote, 10 percent chlorite, five percent white mica, two percent albite, and one percent quartz. Hornblende is coarse, 1 to $2 \mathrm{~mm}$ long, slightly pleochroic, light greenish brown, and partially altered to chlorite and actinolite. Epidote forms in clots, and crystals are anhedral to subhedral. Actinolite is 0.5 to $1 \mathrm{~mm}$ and replaces hornblende. Chlorite is found as minor replacement of hornblende. White mica is 0.1 to $0.5 \mathrm{~mm}$, somewhat oriented in foliation, tabular, and discontinuous. Albite is fine-grained, anhedral, and twinned, and found filing fractures. Minor quartz is present with subgrains. Sample has small, 0.2 to $0.5 \mathrm{~mm}$ quartz veinlets running through the thin section. 
Sample 19ET158 yielded a population of anhedral to subhedral, equant zircon grains typically ranging in length from $75-100 \mu \mathrm{m}$ (fig. 23A). CL-bright rims with oscillatory zonation were too narrow to be analyzed. Spot locations are typically within the core of the crystal where straight, and sector zonation textures are common.

\section{$19 E T 045$}

Orthogneiss; pink-tan; gneissic; grain size: 0.5 to $8 \mathrm{~mm}$; granitic composition. Mineralogy: dominated by feldspar and quartz, plus five percent white mica, three percent biotite, three percent epidote, one percent $\mathrm{K}$-feldspar, one percent chlorite, one percent opaque minerals, and 0.1 percent titanite. Feldspar crystals 4 to $8 \mathrm{~mm}$ long and quartz porphyroclasts in a finer-grained quartz-feldspar matrix form layers that are parted by biotite, white mica, and mafics. Contains 1 to $2 \mathrm{~mm}$ long mafic relicts altered to a mixture of epidote, chlorite, biotite, and opaque minerals. The rock has a well-developed gneissic texture and L-S fabric. Sample taken from float.

Sample 19ET045 yielded a population of anhedral to subhedral, equant to elongated zircon crystals with long axes ranging in size from approximately 100-200 $\mu \mathrm{m}$ (fig. 24A). Internal textures are primarily oscillatory and straight zonation, with the more equant crystals displaying better oscillatory zonation than the elongated crystals. Several grains display CL-bright rims too narrow to analyze. Fracturing in cores and crosscutting straight zonation are common.

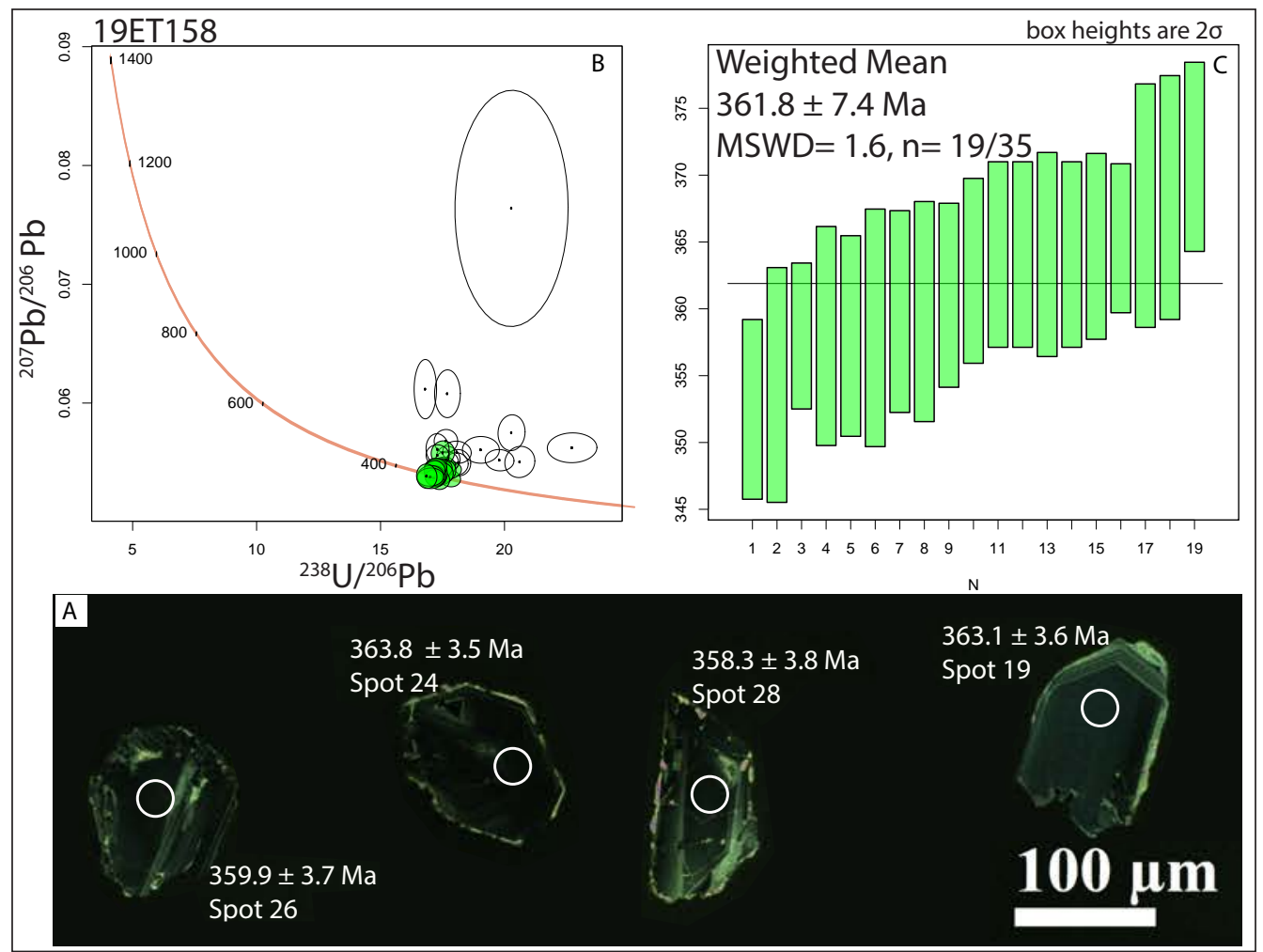

Figure 23. U-Pb data for sample 19ET158. A. Cathodoluminescence images of representative zircon population with spot location and age. B. Tera-Wasserburg concordia diagram. C. Plot of ${ }^{206} \mathrm{~Pb} / 238 \mathrm{U}$ ages with weighted average of preferred ages. Ovals and bars indicate uncertainty at the 2-sigma level. 


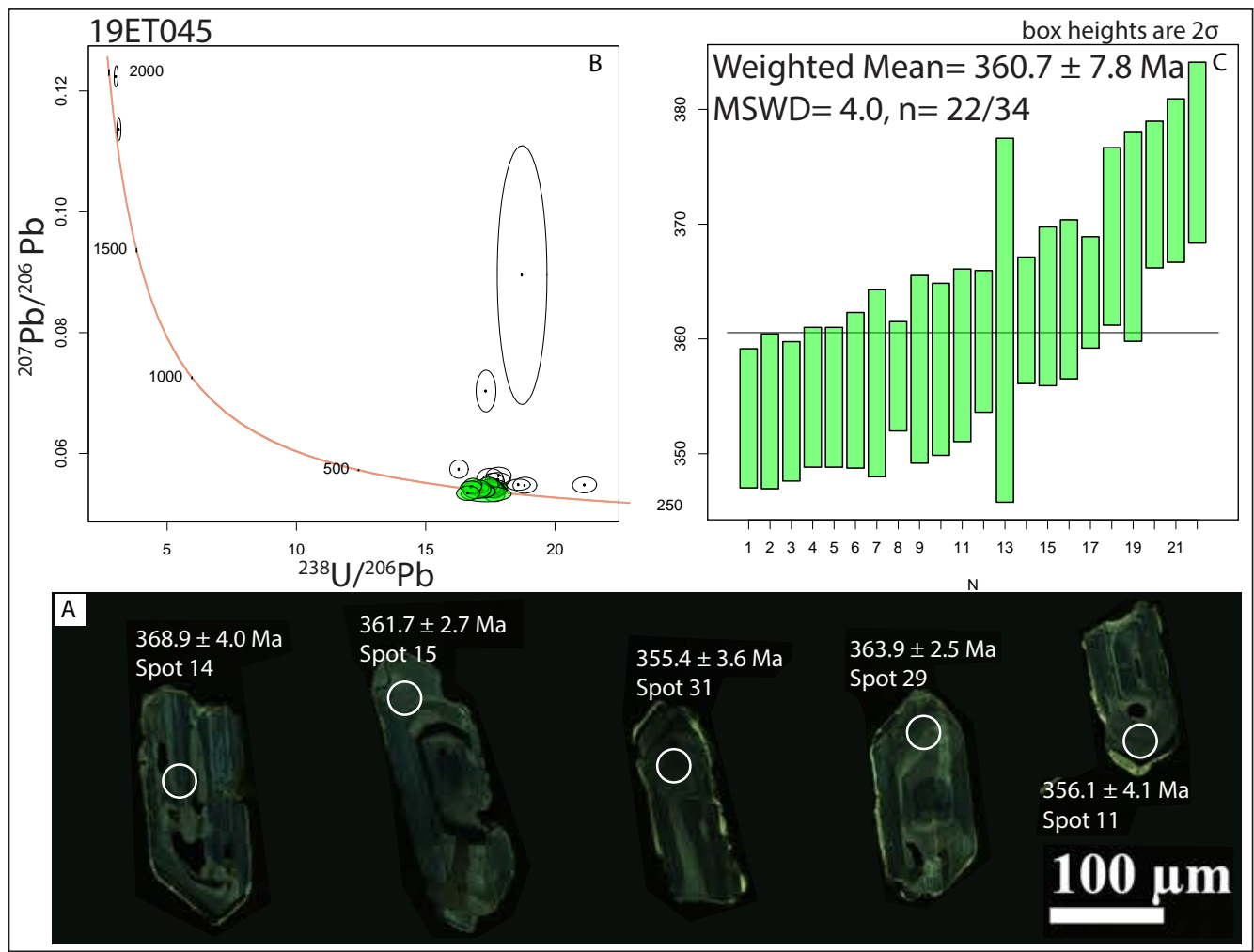

Figure 24. U-Pb data for sample 19ET045. A. Cathodoluminescence images of representative zircon population with spot location and age. B. Tera-Wasserburg concordia diagram. C. Plot of ${ }^{206} \mathrm{~Pb} /{ }^{238} \mathrm{U}$ ages with weighted average of preferred ages. Ovals and bars indicate uncertainty at the 2-sigma level.

\section{AW285}

Orthogneiss; creamy with light green streaks, weathers pale brown; gneissic; grain size: 1 to $7 \mathrm{~mm}$; mineralogy: 50 percent albite, 35 percent quartz, 10 percent chlorite, and five percent white mica, with minor titanite and epidote. Weathering: trace. Rotated albite porphyroclasts, quartz porphyroclasts, and rare quartz augen form irregular felsic layers. The felsic layers are parted by thin ( 1 to $2 \mathrm{~mm}$ ) layers of chlorite (which has been somewhat altered to fine-grained secondary biotite and opaque minerals), white mica, and epidote. The chlorite also appears to be replacing primary igneous biotite. Sample taken from outcrop.

Sample 19AW285 yielded a population of subhedral zircon crystals typically with $150 \mu \mathrm{m}$ long axes, oscillatory zonation, and inherited cores (fig. 25A). Straight zonation is observed but less common. Irregular textures may be due to possible recrystallized or newly grown domains.

\section{WCW067}

Metagranitoid; gray-green, white; foliated; grain size: 0.5 to $3 \mathrm{~mm}$; mineralogy: alkali-feldspar and quartz, plus about 20 percent muscovite, 10 percent plagioclase, eight percent chlorite, and two percent biotite. There is a foliation that is also crenulated, but the crenulations are irregular. Sample taken from float.

Sample 19WCW067 yielded a population of anhedral zircon crystals ranging in length from approximately $50-100 \mu \mathrm{m}$ (fig. 26A). Crystals are typically fractured and broken with irregular textures and domains common. Several grains are subhedral and display oscillatory zonation. 


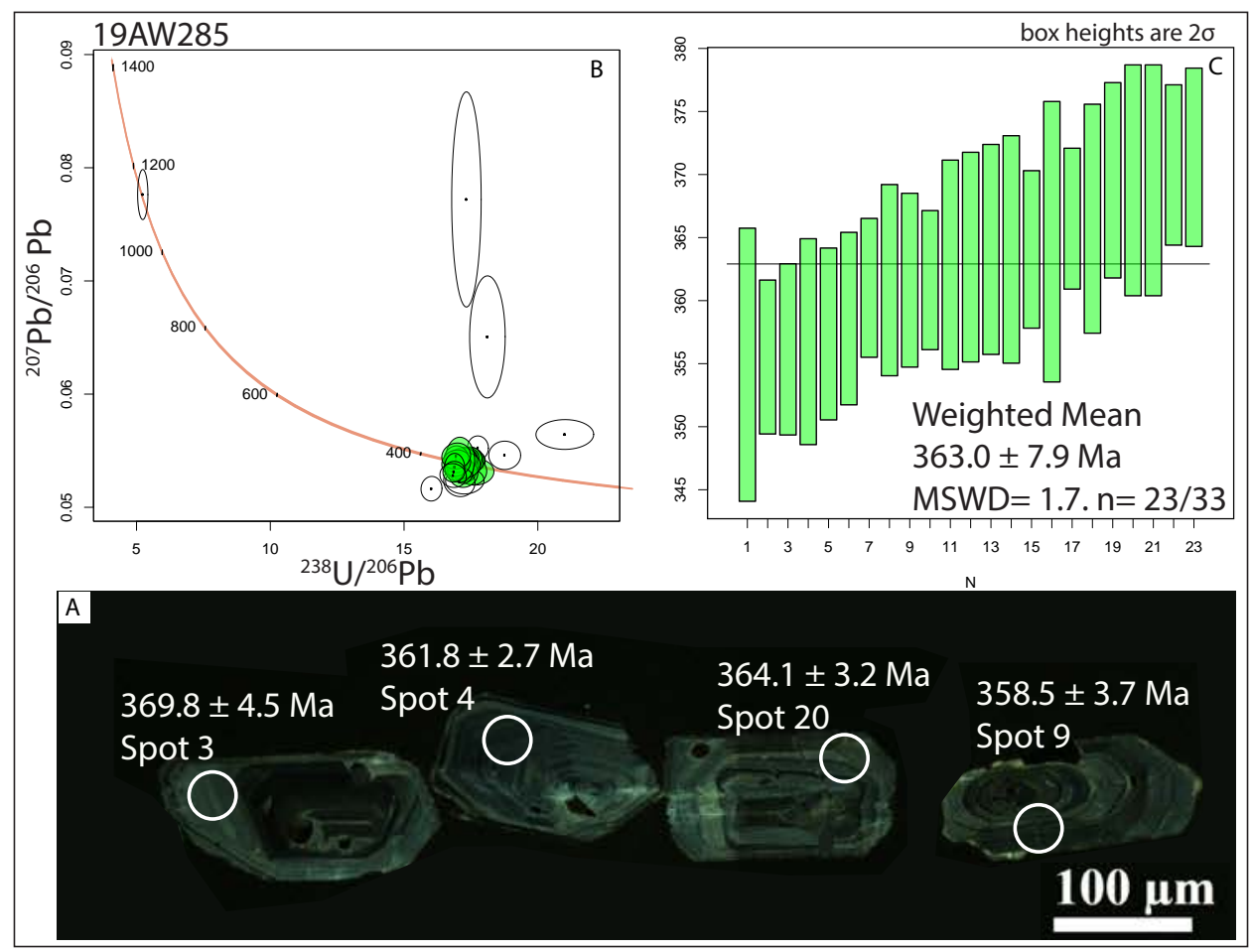

Figure 25. U-Pb data for sample 19AW285. A. Cathodoluminescence images of representative zircon population with spot location and age. B. Tera-Wasserburg concordia diagram. C. Plot of ${ }^{206} \mathrm{~Pb} /{ }^{238} \mathrm{U}$ ages with weighted average of preferred ages. Ovals and bars indicate uncertainty at the 2-sigma level.

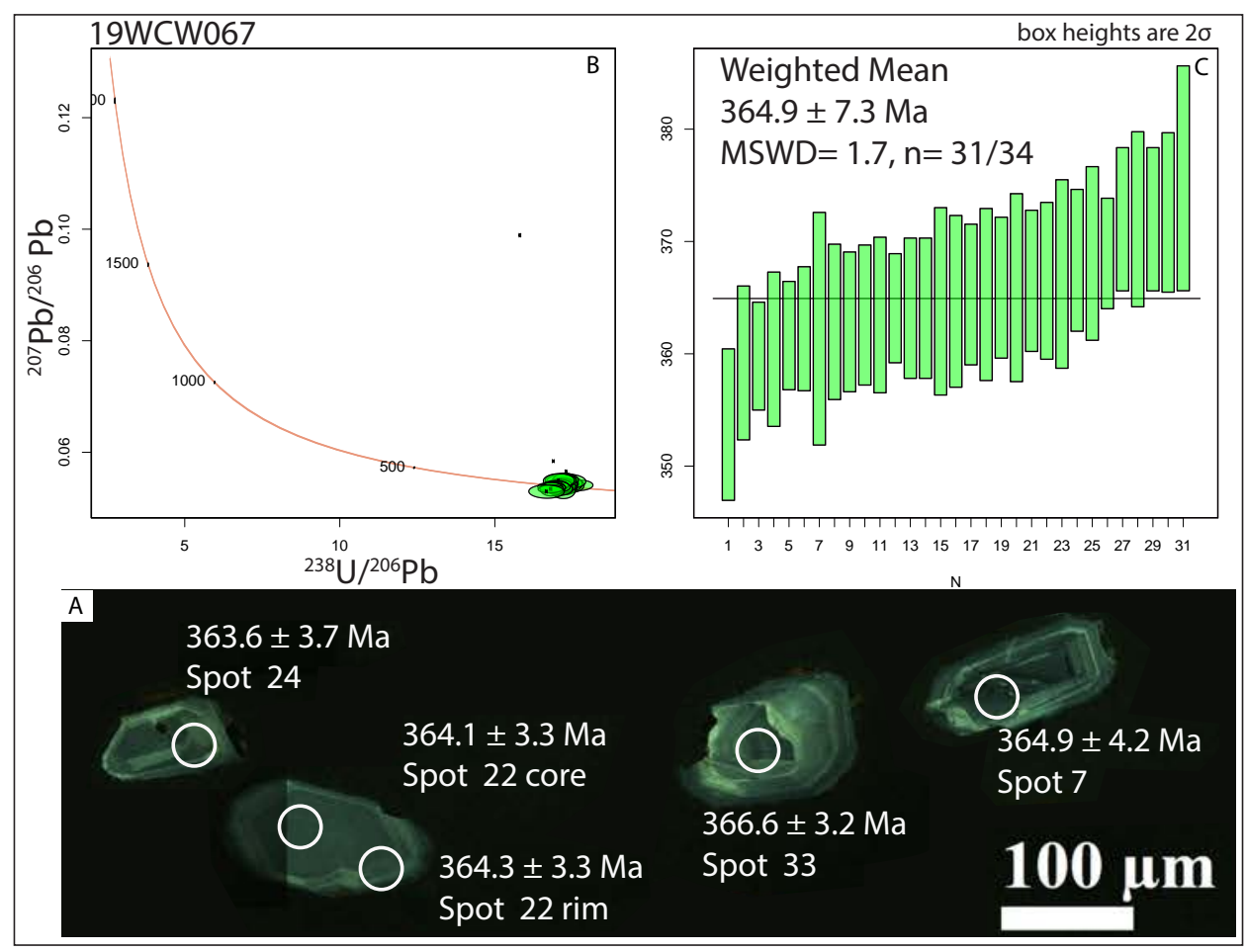

Figure 26. U-Pb data for sample 19WCW067. A. Cathodoluminescence images of representative zircon population with spot location and age. B. Tera-Wasserburg concordia diagram. C. Plot of ${ }^{206} \mathrm{~Pb} / 238 \mathrm{U}$ ages with weighted average of preferred ages. Ovals and bars indicate uncertainty at the 2-sigma level. 


\section{RN278}

Chloritic orthogneiss; green; foliated; gneissic; porphyroclastic; grain size: 0.3 to $5 \mathrm{~mm}$; mineralogy: 40 percent quartz, 20 percent albite, 20 percent K-feldspar, five percent chlorite, three percent epidote, one percent biotite, and trace allanite. Quartz is typically 0.5 to $1 \mathrm{~mm}$ but granulated to $0.1 \mathrm{~mm}$ and forms 0.5 to $1 \mathrm{~mm}$ bands between biotite layers, with undulose extinction and grain boundary migration. Albite is 0.5 to $1 \mathrm{~mm}$ and has rare twinning. K-feldspar is 0.5 to $1 \mathrm{~mm}$, very weathered, partially replaced by sericite, and slightly augen-like in shape with epidote inclusions and sweeping extinction through tails. Chlorite is replacing most biotite crystals. Epidote has euhedral crystal shape and is growing in biotite bands. Biotite is very pleochroic, light green-brown, and forms in sub-mm bands. Allanite is euhedral, brown, and zoned. Partial weathering is present through sample. Sample taken from subcrop.

Sample 19RN278 yielded a population of sub- to euhedral, equant to elongated zircon crystals. Long axes of the crystals are typically 100-200 $\mu \mathrm{m}$ but can be upwards of $300 \mu \mathrm{m}$. Oscillatory zonation occurs more frequently than straight zonation. Fractures crosscutting zonation are common, and occasionally a crystal will be broken. Several zircon crystals have CL-bright rims that are too narrow for analysis.

\section{SPR004}

Alkali feldspar metagranitoid; porphyritic; grain size: 5 to $15 \mathrm{~mm}$. Weakly strained granitic rock with altered plagioclase. No consistent fabric. Mineralogy: 40 percent quartz, 40 percent K-feldspar, 15 percent plagioclase, two percent biotite, and secondary chlorite, epidote, and white mica. Quartz grains are typically $0.3 \mathrm{~mm}$ with some larger subhedral grains up to $4 \mathrm{~mm}$, are mostly interstitial, and display undulose extinction. K-feldspar grain size is $\sim 5 \mathrm{~mm}$ with occasional single twins. Relict plagioclase grains were 2 to $5 \mathrm{~mm}$ and are now entirely replaced by aggregates of white mica, epidote, and sparse chlorite. Biotite is $2 \mathrm{~mm}$ long and entirely replaced by chlorite, but crystal form and cleavage are preserved. Chlorite, epidote, and white mica are secondary after biotite and plagioclase. Sample taken from subcrop.

Sample 19SPR004 yielded a population of euhedral and elongated zircon crystals with long axes ranging in length from 100-150 $\mu \mathrm{m}$ (fig. 34). Majority of the crystals are whole, however a few grains have been fractured and are missing parts. Internal textures of crystals used to calculate the weighted mean age are magmatic with clear oscillatory zonation. Approximately 80 percent have been interpreted to have undergone $\mathrm{Pb}$-loss or are metamict. Inherited and/or metamorphic cores are present but not common.

\section{Parautochthonous Lake George Assemblage 19ADW351C}

Augen orthogneiss; pink; foliated; strained, mylonitic, porphyroclastic; grain size: 3 to $30 \mathrm{~mm}$; mineralogy: 40 percent feldspar, 40 percent quartz, 10 percent biotite, 10 percent muscovite, and trace garnet and chlorite. Subrounded and stretched quartz and feldspar are between 2 to $4 \mathrm{~mm}$ in diameter. K-feldspar porphyroclasts are stretched with foliation, reduced in grain size, and somewhat altered to sericite. Biotite is 0.1 to $0.5 \mathrm{~mm}$ long, forms books defining foliation, and has zircon inclusions and metamict zones. Muscovite is typically 0.1 to $0.2 \mathrm{~mm}$ long and aligned in the foliation alongside biotite. Small, fractured grains of garnet are present. Sample is partially weathered and was collected from an outcrop.

Sample 19ADW351c yielded a population of anhedral to subhedral zircon crystals with long axes ranging from approximately 75-125 $\mu \mathrm{m}$ (fig. 27A). CL imaging of zircon grains reveals internal textures of primarily oscillatory and straight zonation. The abundant inherited cores observed were avoided during analysis. 


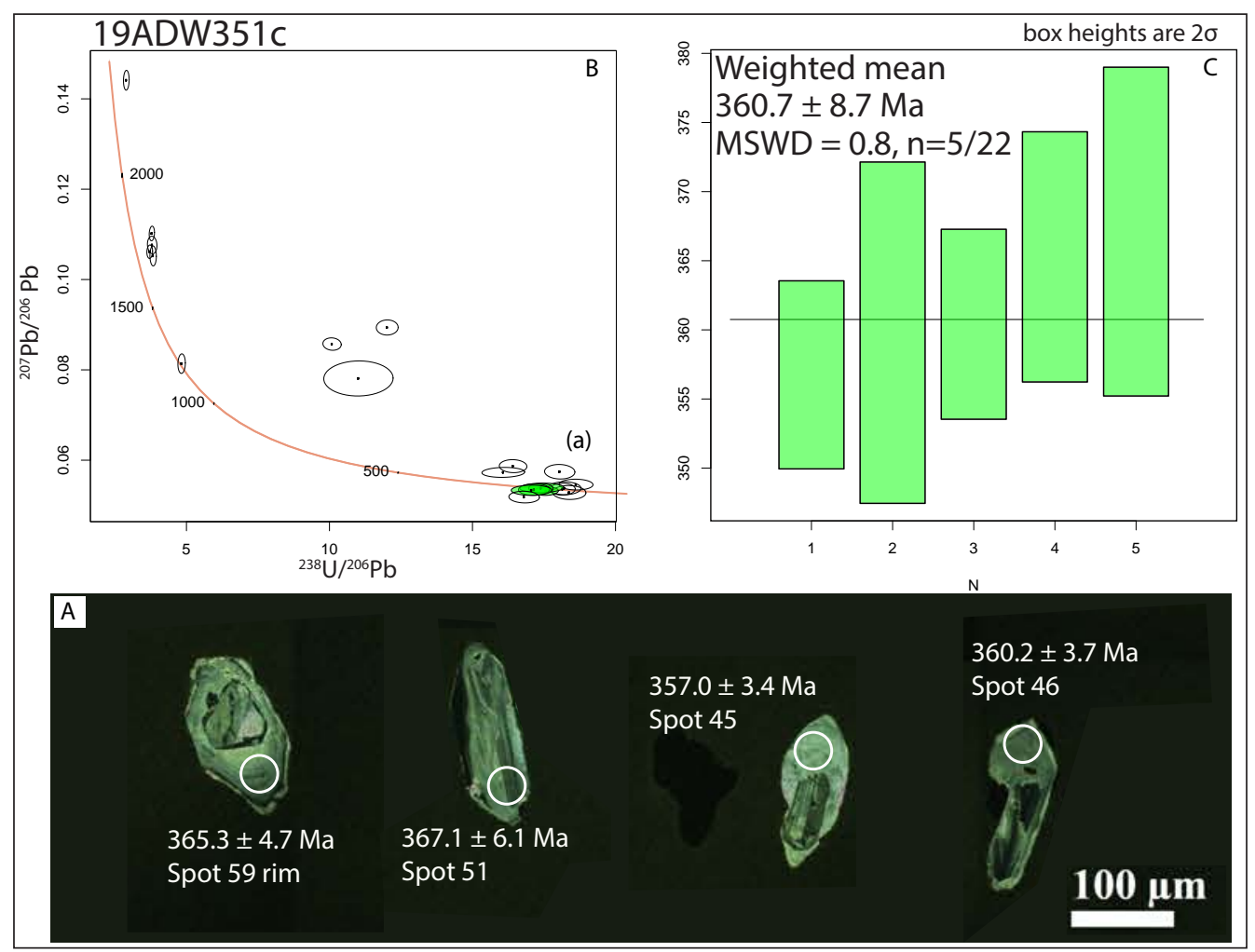

Figure 27. U-Pb data for sample 19ADW351c. A. Cathodoluminescence images of representative zircon population with spot location and age. B. Tera-Wasserburg concordia diagram. C. Plot of ${ }^{206} \mathrm{~Pb} /{ }^{238} \mathrm{U}$ ages with weighted average of preferred ages. Ovals and bars indicate uncertainty at the 2-sigma level.

\section{SPR 174}

Granite; phaneritic; equigranular; grain size: 2 to $15 \mathrm{~mm}$; mineralogy: 50 percent K-feldspar, 25 percent quartz, 10 percent plagioclase, 10 percent biotite, three percent white mica, and two percent chlorite. K-feldspar is subhedral, often shows Carlsbad twins, includes inclusions of biotite, and is strongly replaced by sericite. Quartz is anhedral to subhedral, with some irregular grain boundaries. Plagioclase is commonly twinned and weathered, with some sericite replacement. Biotite crystals are typically $1 \mathrm{~mm}$ long and appear as randomly oriented books. Secondary chlorite is found replacing biotite. This sample of undeformed granite was collected from the base of outcrop, $1.5 \mathrm{~m}$ below mylonitic augen orthogneiss of similar age and composition (sample 19ADW351c).

Sample 19SPR174 yielded a population of subhedral equant to elongated zircon crystals ranging in length from 125-200 $\mu \mathrm{m}$ (fig. 28A). CL imaging reveals many inherited cores with occasional metamict zones. Subsequent zircon crystal growth around cores shows oscillatory and straight zonation. Fractures (and possibly holes) are commonly found throughout the population.

\section{ADW202}

Meta-leucogranite; weakly stained; grain size: 0.5 to $2 \mathrm{~mm}$; mineralogy: 55 percent feldspar, 25 percent quartz, 15 percent biotite, three percent garnet, and two percent oxides. Rock is weakly foliated, with small metamorphic garnets. Biotite is 0.2 to $0.5 \mathrm{~mm}$, weakly aligned in fabric, and fresh looking, 


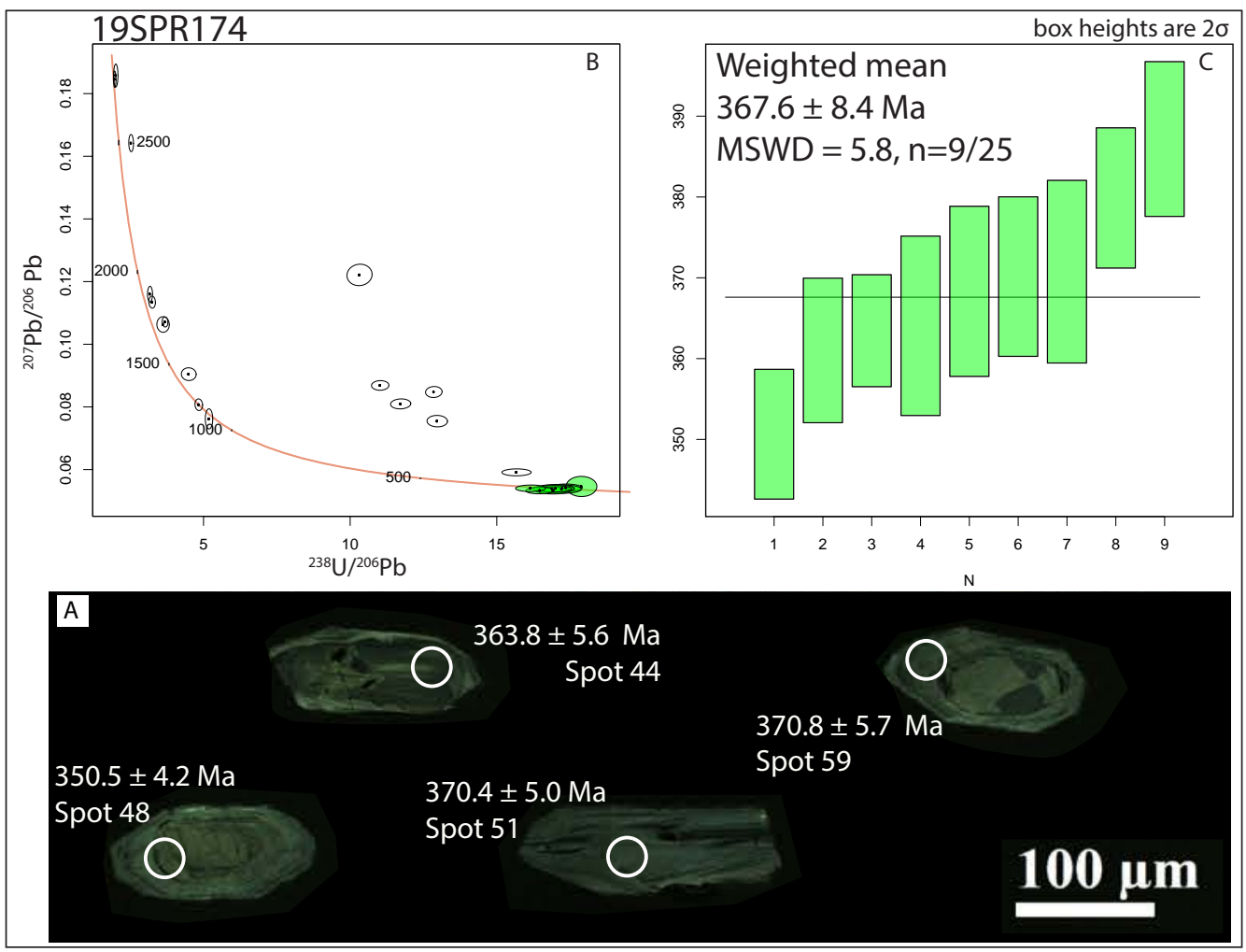

Figure 28. U-Pb data for sample 19SPR174. A. Cathodoluminescence images of representative zircon population with spot location and age. B. Tera-Wasserburg concordia diagram. C. Plot of ${ }^{206} \mathrm{~Pb} /{ }^{238} \mathrm{U}$ ages with weighted average of preferred ages. Ovals and bars indicate uncertainty at the 2-sigma level.

with bird's eye extinction and metamict zones with zircon. Quartz is 0.5 to $2 \mathrm{~mm}$ in diameter, somewhat elongated in fabric with straight grain boundaries, and sometimes present as subgrains, with undulatory extinction. Feldspar is weathered looking and displays occasional twinning. Garnet is about $0.2 \mathrm{~mm}$ in diameter and is fractured. Sample found in outcrop.

Sample 19ADW202 yielded a population of subhedral, equant to elongated zircon crystals with long axes ranging in size from approximately 100-200 $\mu \mathrm{m}$ (fig. 29A). CL imaging of zircon grains reveals ubiquitous CL-bright rims that were too narrow to be analyzed. Internal textures were primarily oscillatory and straight zonation, with abundant inherited cores. CL-dark grains were interpreted to be metamict and were avoided during analysis.

\section{Parautochthonous Jarvis Belt 19ET034}

Metarhyolite; light tan; porphyritic, possible protomylonitic texture, weakly foliated; grain size: 0.05 to $4 \mathrm{~mm}$; mineralogy: 20 percent white mica, five percent quartz, one percent plagioclase, one percent mafic, and one percent epidote. Weathering: partial. Dominated by sub-50- $\mu \mathrm{m}$ groundmass, recrystallized in a post-kinematic environment with crenulation cleavage developing. Contains porphyroclasts of $2 \mathrm{~mm}$ plagioclase feldspars with relict twinning, quartz, biotite, and highly altered to opaque minerals in a very fine-grained matrix of white mica, quartz, and feldspar. The white mica defines foliation and incipient crenulation cleavage. The epidote is less than $100 \mu \mathrm{m}$ in size, is dispersed through the rock, and is lustrous 


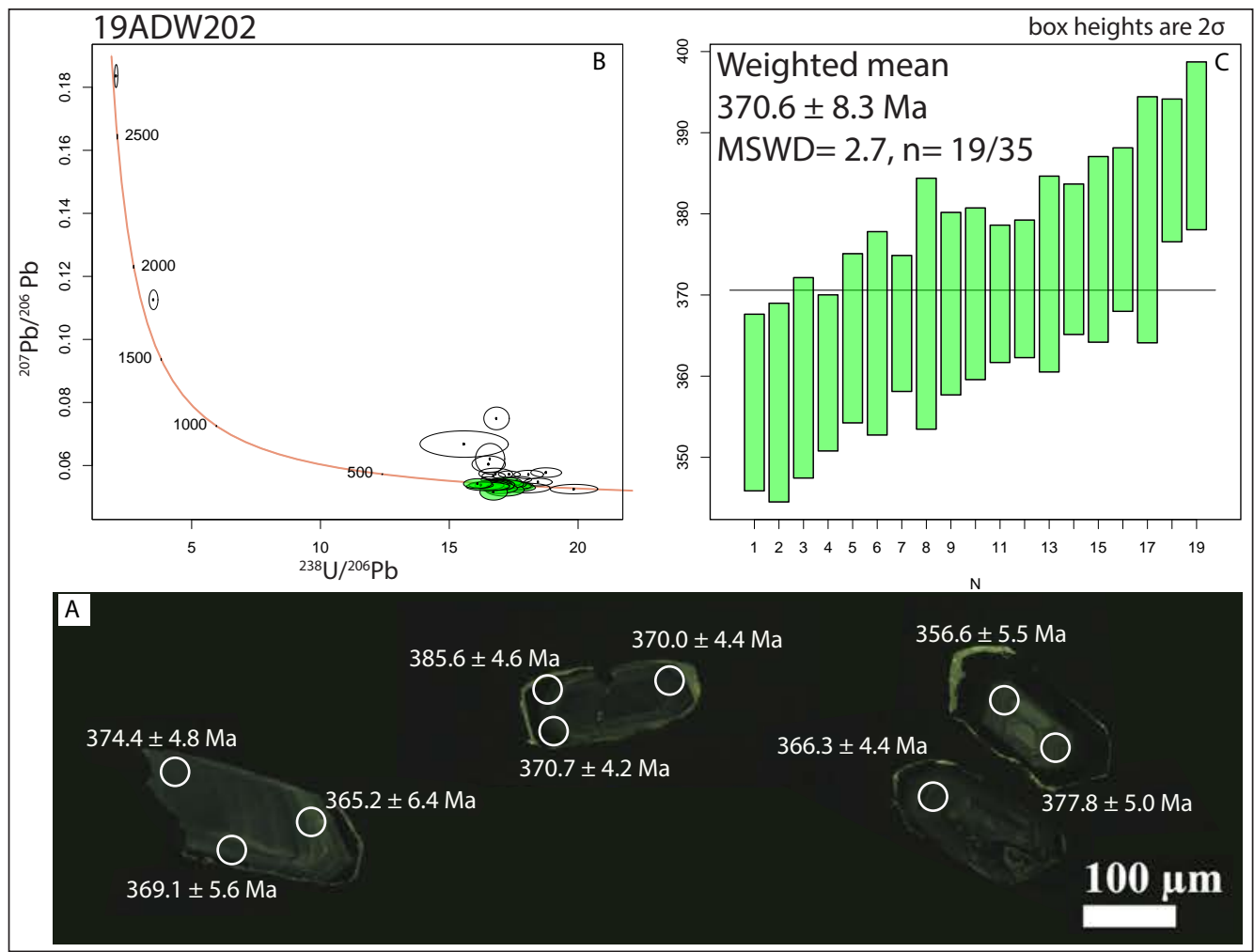

Figure 29. U-Pb data for sample 19ADW202. A. Cathodoluminescence images of representative zircon population with spot location and age. B. Tera-Wasserburg concordia diagram. C. Plot of ${ }^{206} \mathrm{~Pb} /{ }^{238} \mathrm{U}$ ages with weighted average of preferred ages. Ovals and bars indicate uncertainty at the 2-sigma level.

on cleaved surfaces. Sparse quartz veinlets are sinuous and deformed. The rock is possibly retrograded from either greenschist-facies or amphibolite-facies. Sample was collected from subcrop.

Sample 19ET034 yielded a population of anhedral to subhedral zircon crystals typically ranging in length from 100-200 $\mu \mathrm{m}$ (fig. 36). Internal textures were primarily oscillatory, and inherited cores are common. Often the crystals display fractures and are broken with jagged edges.

\section{RESULTS AND DISCUSSION}

A summary of all interpreted $\mathrm{U}-\mathrm{Pb}$ ages is included in table 2, with uncertainty for all ages, isotope ratios, and reported MSWD. As outlined above, a concordance filter was used to eliminate grains that were either heterogeneous or experienced $\mathrm{Pb}$ loss after formation. Filtered grains were not included in the final interpreted ages reported below.

\section{Igneous Rocks Paleogene}

A rhyolite ( $\mathrm{REr}$ ), 19AW256, and two feldspar-porphyry samples ( $\mathrm{PEfp}), 19 \mathrm{ET} 277$ and 19KS100, returned $58.9 \pm 1.4,58.6 \pm 1.4$ and $57.1 \pm 1.2$ Ma ages (figs. 2-4, table 2). The zircon grains' morphology and lack of $\mathrm{Pb}$ loss suggest the ages represent zircon crystallization under magmatic conditions. An equivalent of this granite porphyry is observed in Yukon, Canada, at the North Ladue River Porphyry, which yielded a similar zircon age: $58.3 \pm 0.5 \mathrm{Ma}$ (Yukon Geological Survey, 2020). Furthermore, a sanidine sample from a welded tuff in the eastern area of the Tanacross quadrangle yielded a 57.8 $\pm 1.7 \mathrm{Ma} \mathrm{K}$-Ar age (Foster and others, 1976; recalculated by Wilson and others, 2015). 


\section{Late Cretaceous}

The youngest Late Cretaceous unit that was sampled within the field area is a porphyritic granite (lKpg, 19RN287) which yielded a $68.8 \pm 1.5 \mathrm{Ma}$ zircon age (fig. 5, table 2). Three samples of granodiorite (lKgd): 19TJN243, 19RN282, and 19WCW037, yielded ages $69.3 \pm 1.4$ to $72.1 \pm 1.6 \mathrm{Ma}$ and a felsic dike, 19RN359, $70.5 \pm 1.6 \mathrm{Ma}$ (figs. 6-7 and 30, table 2). These ages are interpreted as igneous crystallization ages for the units. The range of ages of the Late Cretaceous rocks from eastern Tanacross field area is very similar to those observed in the northeast Tanacross Quadrangle: 68 to $72 \mathrm{Ma}$ (Todd and others, 2019).
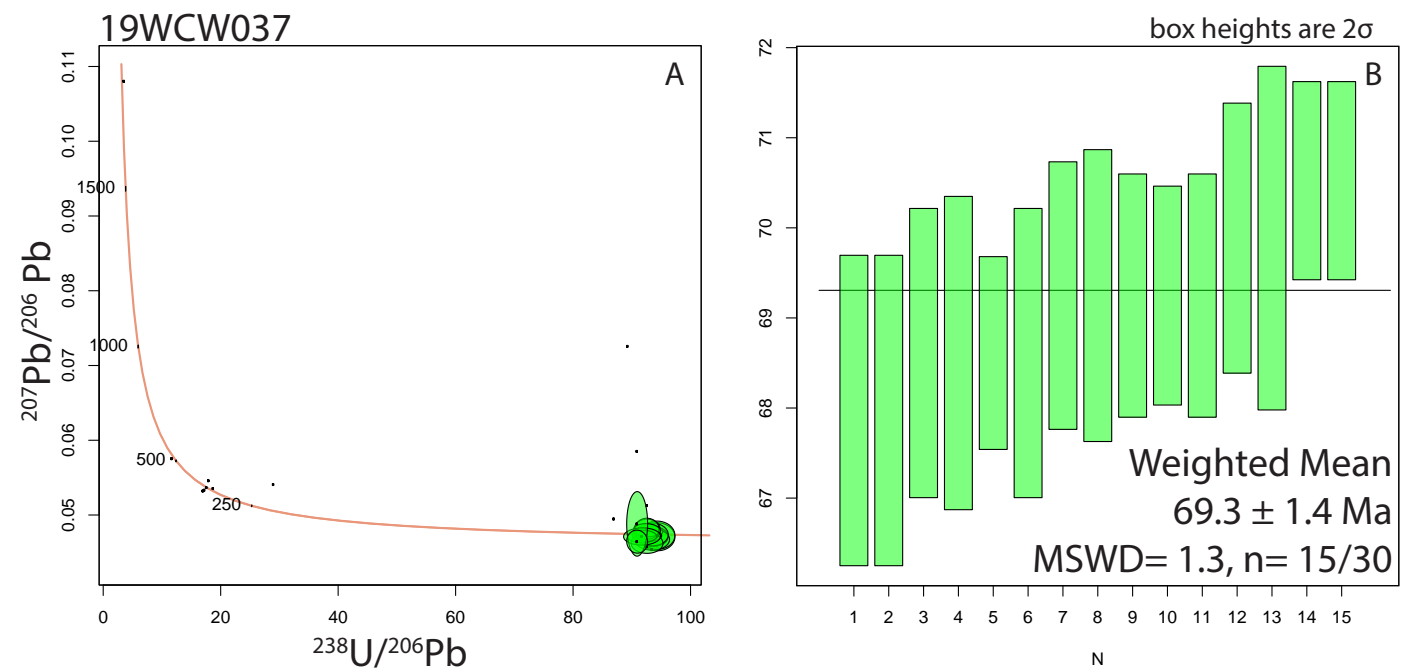

Figure 30. (A) U-Pb Tera-Wasserburg Concordia and (B) weighted mean age plots for sample 19WCW037.

\section{Mid-Cretaceous}

The mid-Cretaceous intrusive rocks range between 100 to $115 \mathrm{Ma}$. Dikes having mafic to intermediate alkalic compositions are represented by sample 19ADW053, which yielded the youngest age in the mid-Cretaceous group: 100.3 $\pm 2.2 \mathrm{Ma}$ (fig. 9, table 2). Granodiorite (unit Kgd; samples: 19ET054 and 19JEA029) are characterized by the ages $104.4 \pm 2.3$ and $107.7 \pm 2.3 \mathrm{Ma}$ (figs. 10 and 31, table 2). The correlative Silver Creek Granodiorite (unit Khgd) from the adjacent Alaska Highway Corridor geologic map (Solie and others, 2019) yielded ages between 97 and $103 \mathrm{Ma}$ (Solie and others, 2014). Mafic to intermediate, calc-alkalic to alkali calcic dikes (Kmi), samples 19ADW016 and 19ET102, yielded zircon ages of 102.8 \pm 2.2 and $110.7 \pm 2.5 \mathrm{Ma}$ (fig. 11, fig. 32A, B table 2). Granite samples, representing unit Kg (19ET146, 19ET288, 19TJN181, 19RN423, 19WCW039) yielded ages from $106.7 \pm 2.3$ to $112.8 \pm 2.6$ (figs. $12-15$ and 32C, D, table 2). Similar ages were reported for the Northeastern Tanacross map unit Kg (Todd and others, 2019; Wypych and others, 2020), and in Yukon, Canada, where it is mapped as the ca. 110-109 Ma Crag Mountain pluton, part of the Whitehorse Plutonic Suite (Yukon Geological Survey, 2019). Zircons from granite porphyry (Kgp; 19AW200, 19RN222, 19TJN231, 19SPR102) returned ages between 107.2 \pm 2.4 and $115.0 \pm 2.5 \mathrm{Ma}$ (figs. 16-19, table 2) and zircons from a rhyolite tuff (Kwff) sample 19TJN299 returned an age of $107.9 \pm 2.2 \mathrm{Ma}$ (fig. 20, table 2). Sample 19SPR027 (Kgb) is gabbroic to dioritic in composition and yielded an age of $108.1 \pm 2.3 \mathrm{Ma}$ (fig. 21, table 2), which is in agreement with the age of the Kgb unit obtained for Alaska Highway Corridor (Solie and others, 2014; 2019). 

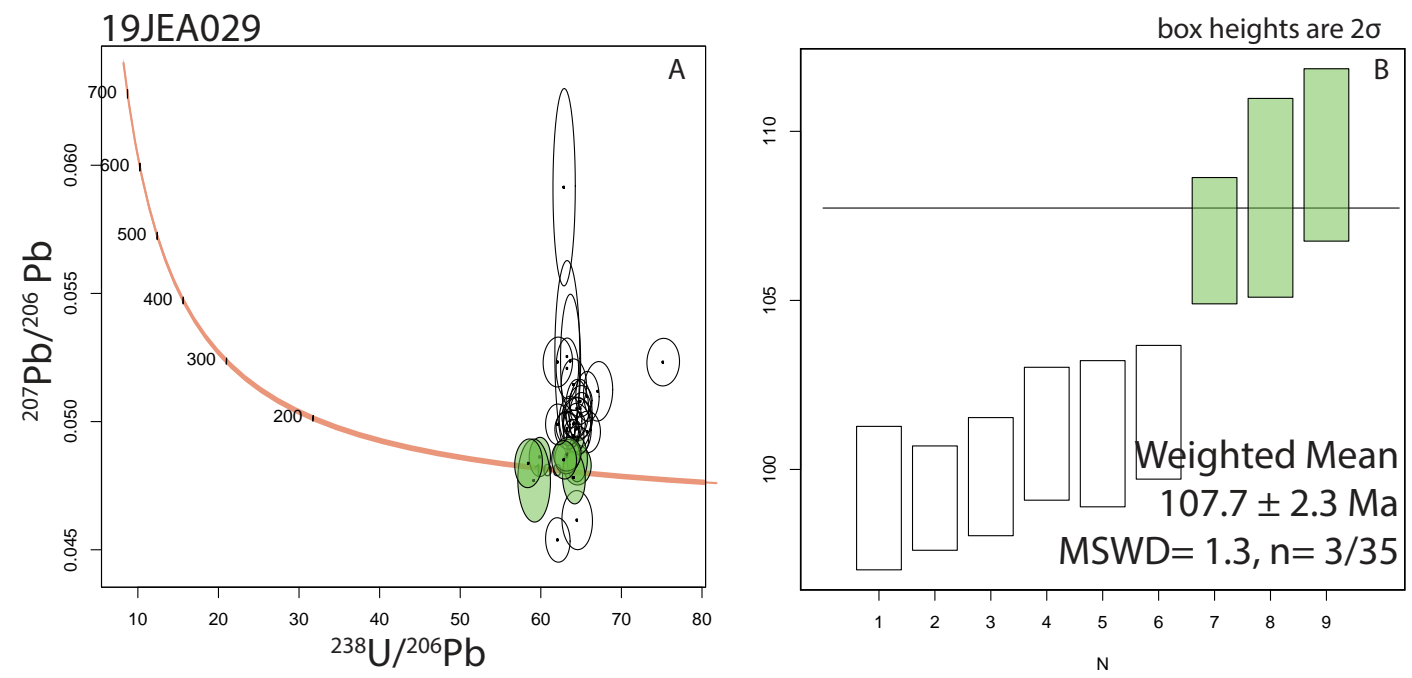

Figure 31. (A) U-Pb Tera-Wasserburg Concordia and (B) weighted mean age plots for sample 19JEA029.
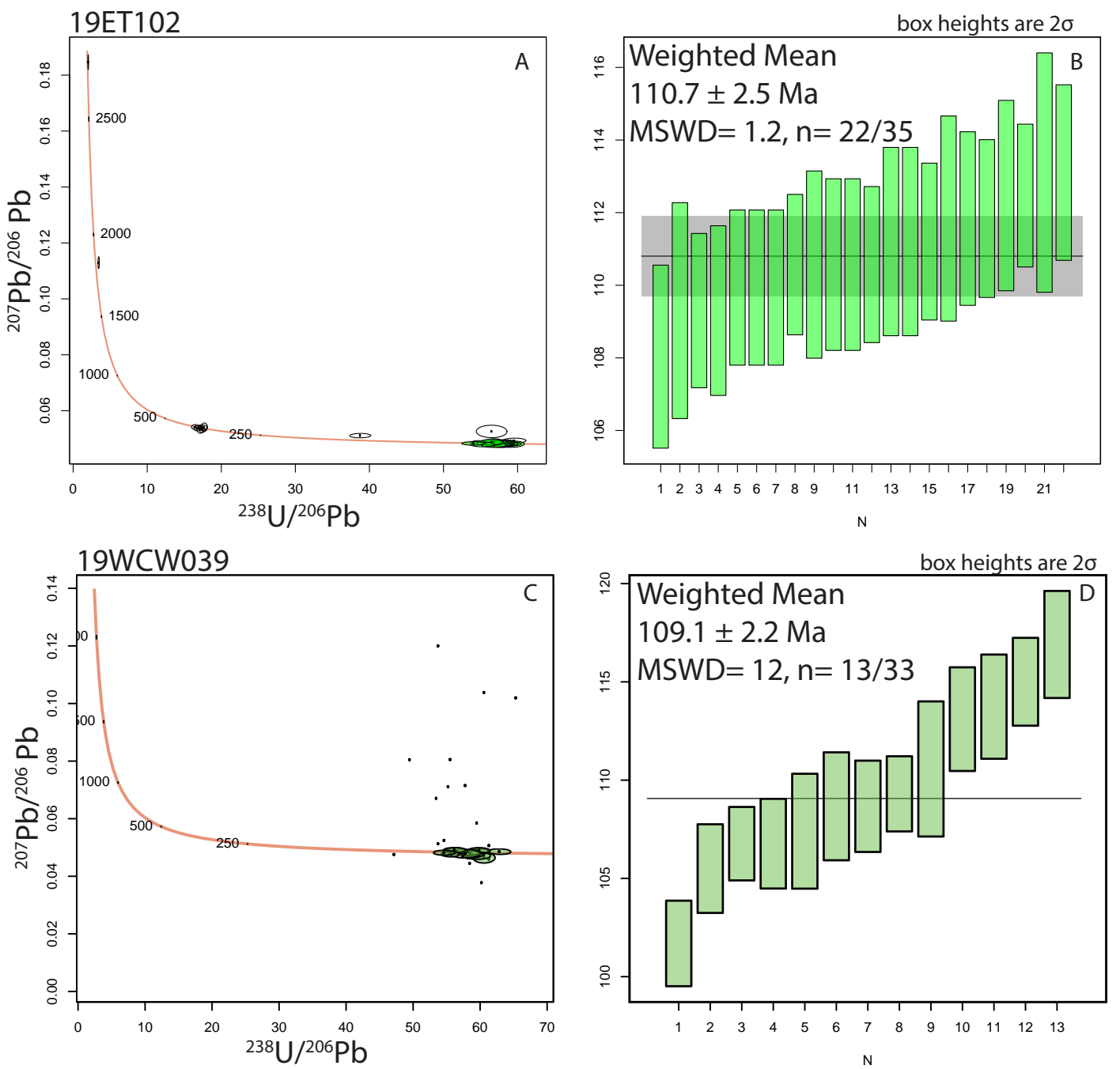

Figure 32. (A) U-Pb Tera-Wasserburg Concordia and (B) weighted mean age plots for samples $19 \mathrm{ET} 102$ and 19 WCW039. 
Common inheritance observed in some samples from the Cretaceous and Paleogene igneous rocks include Mississippian to Devonian as well as Proterozoic age zircons-characteristic of the underlying basement.

\section{Allochthonous Metamorphic rocks Klondike Assemblage}

Two metarhyolite samples (19ET098 and 19ET126) collected within the Klondike Assemblage (Pks) yielded zircon ages of $256.7 \pm 5.8$ and $261.4 \pm 5.8 \mathrm{Ma}$, respectively (figs. 22 and 33, table 2). These ages are in agreement with the 257 and $267 \mathrm{Ma}$ ages reported in Jones and O'Sullivan (2020), which were obtained
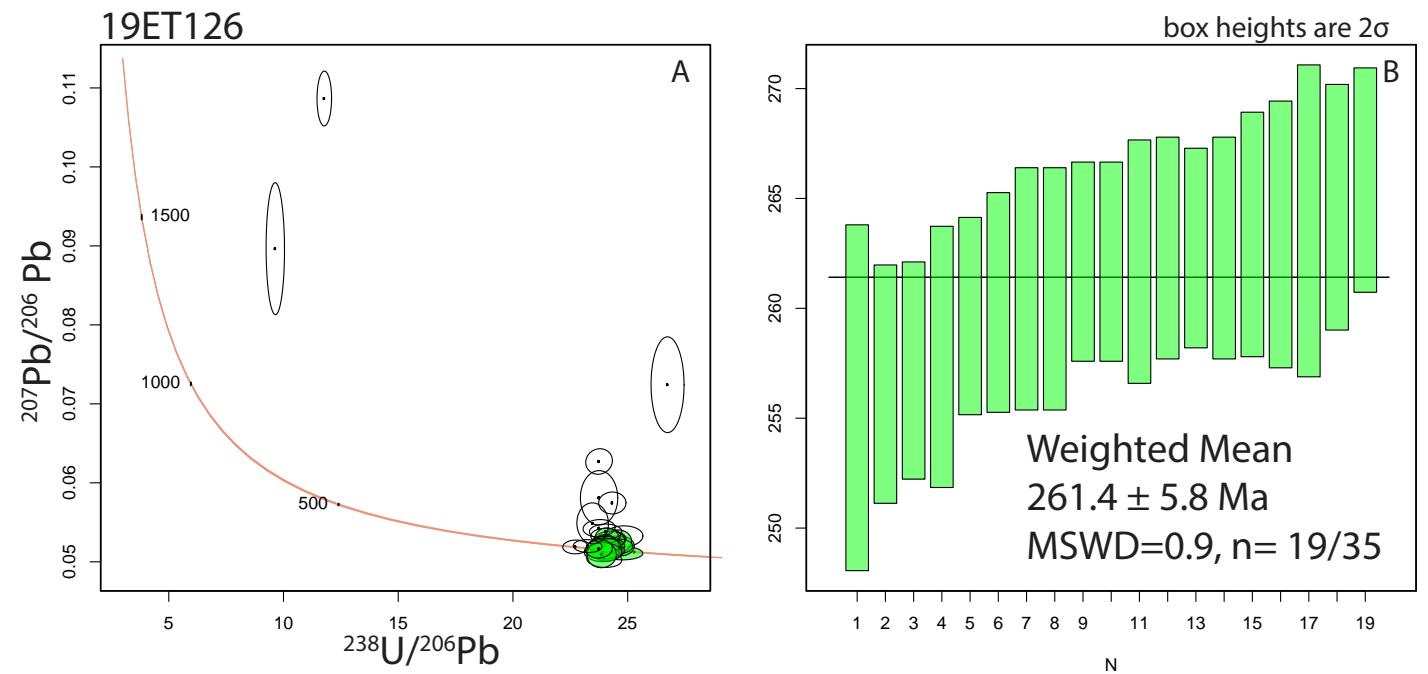

Figure 33. (A) U-Pb Tera-Wasserburg Concordia and (B) weighted mean age plots for sample 19ET126.

from a schist in the vicinity of our samples. We interpret these ages as representing the crystallization of a volcanic protolith. There are a few Proterozoic grains present in 19ET126; however, those ages are a typical inheritance present in both the allochthonous and parautochthonous rocks in the region.

\section{Ladue River Unit}

The Ladue River metaigneous rocks are characterized by Mississippian to Late Devonian ages. Sample 19ET158 is an amphibolite (unit MDa) and yielded an age of 361.8 $\pm 7.4 \mathrm{Ma}$ (fig. 23, table 2), metagranitoid samples 19ET045, 19AW285, 19WCW067, 19RN278, and 19SPR004 (unit MDg) yielded ages ranging from $360.7 \pm 7.8$ to $375.7 \pm 9.0 \mathrm{Ma}$ (figs. $24-26,34 \mathrm{~A}-\mathrm{D}$, table 2), and sample 19WCW048, within the feldspar-porphyroclastic orthogneiss (unit MDpo), yielded an age of $359.7 \pm 7.2 \mathrm{Ma}$ (fig. 35, table 2). These ages are similar to the Mississippian-Devonian Fortymile River assemblage orthogneiss samples from the Eagle A-1 Quadrangle and Northeast Tanacross map (Day and others, 2002; Wypych and others, 2020) and represent a crystallization age of the igneous photolith. The Ladue River unit samples display bright rims; however, they are too fine to resolve their age with laser ablation techniques.

\section{Parautochthonous Metamorphic rocks Lake George Assemblage}

A strained augen orthogneiss, 19ADW351c, and unstrained porphyritic granite, 19SPR174, both mapped as augen gneiss unit MDag, yielded Late Devonian ages of 360.7 \pm 8.7 and $367.6 \pm 8.4 \mathrm{Ma}$, respec- 

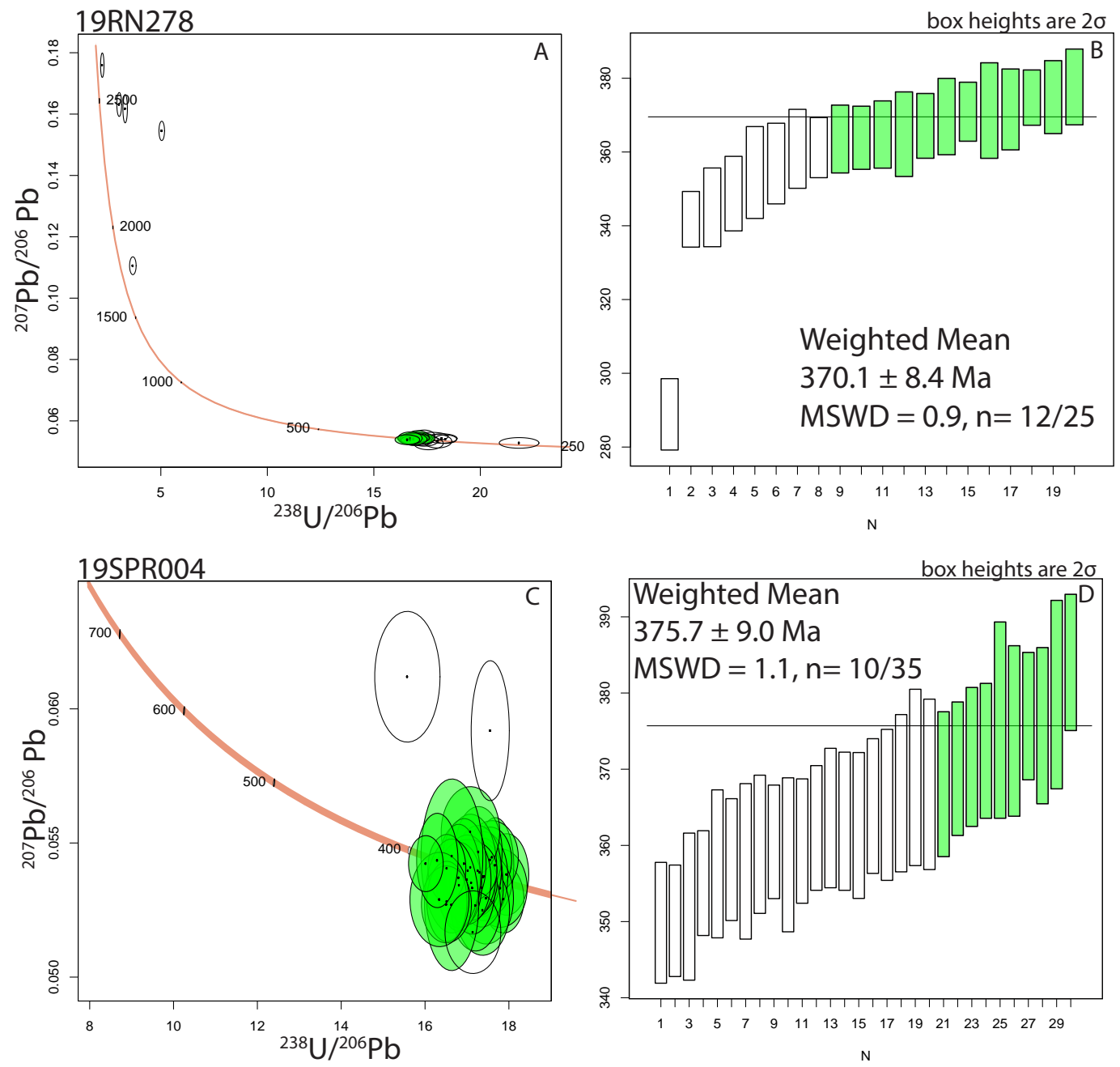

Figure 34. (A,C) U-Pb Tera-Wasserburg Concordia and (B,D) weighted mean age plots for samples $19 \mathrm{RN} 278$ and 19SPR004, respectively.
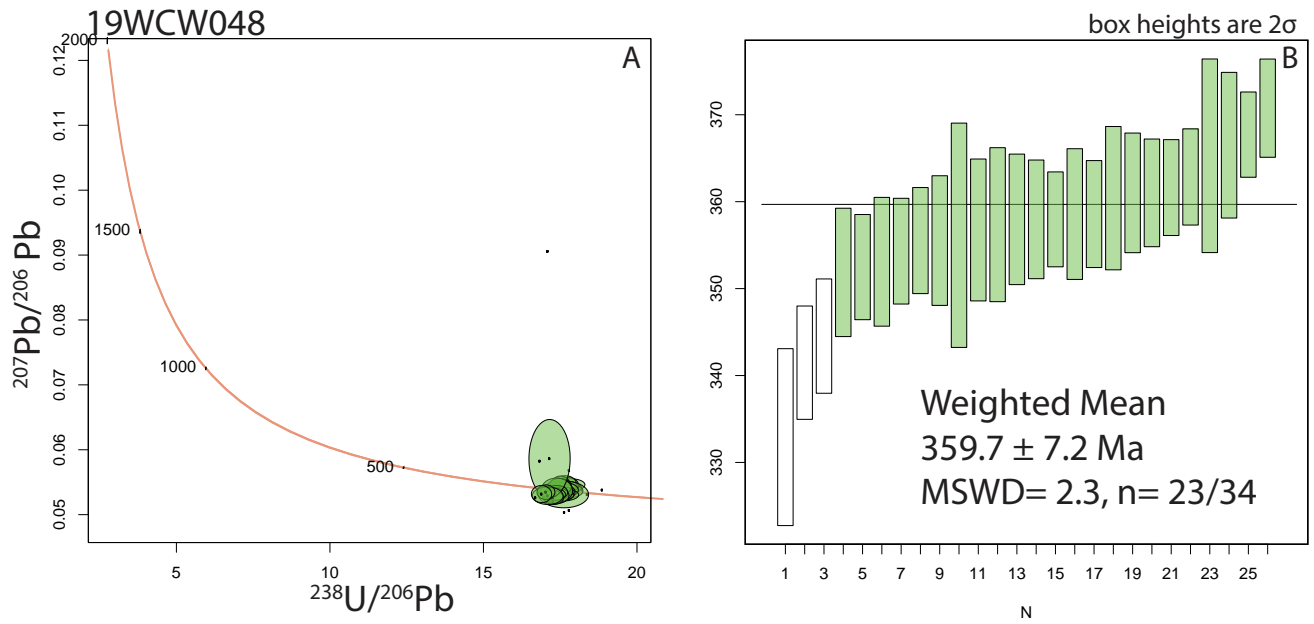

Figure 35. (A) U-Pb Tera-Wasserburg Concordia and (B) weighted mean age plots for sample 19WCW048. 
tively (figs. 27 and 28, table 2) - similar to those observed in the Northeast Tanacross map area (Todd and others, 2019; Wypych and others, 2020) and Alaska Highway Corridor (Solie and others, 2014). Additionally, an orthogneiss sample (19ADW202) from unit MDlo yielded an age of $370.6 \pm 8.3 \mathrm{Ma}$ (fig. 29). All the samples have minimal $\mathrm{Pb}$ loss and are interpreted to represent crystallization of the igneous protoliths. Inherited zircons found within the zircon population of the Lake George assemblage metasedimentary units are of typical Precambrian age.
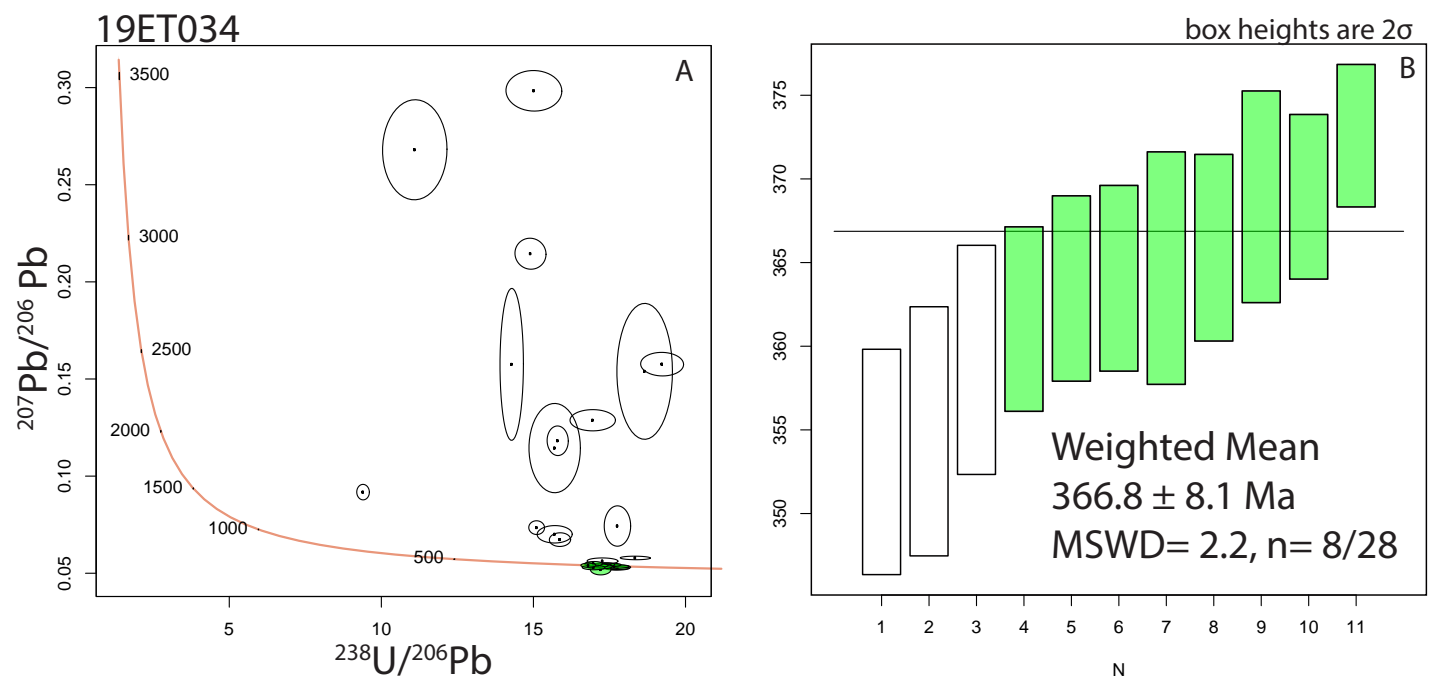

Figure 36. (A) U-Pb Tera-Wasserburg Concordia and (B) weighted mean age plots for sample 19ET034.

\section{Parautochthonous Jarvis Belt}

A sample of metarhyolite (MDmr; 19ET034) yielded an age of 366.8 $\pm 8.1 \mathrm{Ma}$ (fig. 36, table 2). This unit correlates with "felsic schist and quartzite" (unit Ms) from Alaska Highway Corridor map (Solie and others, 2019) and a metarhyolite from that unit yielded a zircon age of 351.7 $\pm 9.3 \mathrm{Ma}$ (Solie and others, 2014).

\section{ACKNOWLEDGMENTS}

The authors would like to thank Jen Athey, Travis Naibert, Rainer Newberry, Karri Sicard, Evan Twelker, and Chris Wyatt of the Division of Geological \& Geophysical Surveys' Mineral Resources Section, Julian Lopez with Colorado College, Jalen Cox and Daisy Herrman with the University of Alaska Fairbanks, and the Arizona LaserChron Center staff for their contributions towards data collection, scientific discussions, and other support.

This project was jointly funded by the State of Alaska and the U.S. Geological Survey's Earth Mapping Resources Initiative (Earth MRI) through cooperative agreement G19AC00262. The views and conclusions contained in this document are those of the authors and should not be interpreted as representing the opinions or policies of the U.S. Geological Survey. Mention of trade names or commercial products does not constitute their endorsement by the U.S. Geological Survey. 


\section{REFERENCES}

Black, L.P., Kamo, S.L., Allen C.M., Davis, D.W., Aleinikoff, J.N., Valley, J.W., Mundil, Roland, Campbell, I.H., Korsch, R.J., Williams, I.S., and Foudoulis, Chris, 2004, Improved ${ }^{206} \mathrm{~Pb} /{ }^{238} \mathrm{U}$ microprobe geochronology by the monitoring of a trace-element-related matrix effect; SHRIMP, ID-TIMS, ELAICP-MS and oxygen isotope documentation for a series of zircon standards: Chemical Geology, v. 2015, no. 1-2, p. 115-140. https://doi.org/10.1016/j.chemgeo.2004.01.003

Coutts, D.S., Matthews, W.A., Englert, R.G., Brooks, M.D., Boivin, Marie-Pier, and Hubbard, S.M., 2020, Along-strike variations in sediment provenance within the Nanaimo basin reveal mechanisms of forearc basin sediment influx events: Lithosphere, v. 12, p. 180-197.

Day, W.C., Aleinikoff, J.N., and Gamble, B.M., 2002, Geochemistry and age constraints on metamorphism and deformation in the Fortymile River area, eastern Yukon-Tanana Upland, Alaska, in Wilson, F.H., and Galloway, J.P., eds., Studies by the U.S. Geological Survey in Alaska, 2000: U.S. Geological Survey Professional Paper 1662, p. 5-18.

Dusel-Bacon, Cynthia, Aleinikoff, J.N., Day, W.C., and Mortensen, J.K., 2015, Mesozoic magmatism and timing of epigenetic $\mathrm{Pb}-\mathrm{Zn}$-Ag mineralization in the western Fortymile mining district, east-central Alaska: Zircon U-Pb geochronology, whole-rock geochemistry, and Pb isotopes: Geosphere, v. 11, no. 3. https://doi.org/10.1130/GES01092.1

Dusel-Bacon, Cynthia, Hopkins, M.J., Mortensen, J.K., Dashevsky, S.S., Bressler, J.R., and Day, W.C., 2006, Paleozoic tectonic and metallogenic evolution of the pericratonic rocks of east-central Alaska and adjacent Yukon, in Colpron, Maurice, and Nelson J.L., eds., Paleozoic Evolution and Metallogeny of Pericratonic Terranes at the Ancient Pacific Margin of North America, Canadian and Alaskan Cordillera: Geological Association of Canada Special Paper 45, p. 25-74.

Foster, H.L., Albert, N.R.D., Barnes, D.F., Curtin, G.C., Griscom, Andrew, Singer, D.A., and Smith, J.G., 1976, The Alaskan Mineral Resource Assessment Program; background information to accompany folio of geologic and mineral resource maps of the Tanacross Quadrangle, Alaska: U.S. Geological Survey Circular 734, 19 p.

Gehrels, G.E., Valencia, V.A., and Ruiz, Joaquin, 2008, Enhanced precision, accuracy, efficiency, and spatial resolution of $\mathrm{U}-\mathrm{Pb}$ ages by laser ablation-multicollector-inductively coupled plasma-mass spectrometry: Geochemistry Geophysics Geosystems, American Geophysical Union, v. 9, 13 p.

Horstwood, M.S., Košler, Jan, Gehrels, G.E., Jackson, S.E., McLean, N.M., Paton, Chad, Pearson, N.J., Sircombe, Kieth, Sylvester, Paul, Vermeesch, Pieter, and Bowring, J.F., 2016, Community-derived standards for LA-ICP-MS U-(Th-) Pb geochronology-Uncertainty propagation, age interpretation and data reporting: Geostandards and Geoanalytical Research, v. 40, no. 3, p. 311-332.

Jones III, J.V., and O'Sullivan, Paul, 2020, U-Pb isotopic data and ages of zircon, titanite, and detrital zircon from rocks from the Yukon-Tanana Upland, Alaska: U.S. Geological Survey data release. https://doi. org/10.5066/P9WWV93S

Mattinson, J.M., 1987, U-Pb ages of zircons: A basic examination of error propagation: Chemical Geology: Isotope Geoscience section, v. 66, no.-2, p. 151-162. https://doi.org/10.1016/0168-9622(87)90037-6

Newberry, R.J., 2020, The Mount Fairplay igneous complex: Alaska Division of Geological \& Geophysical Surveys Preliminary Interpretive Report 2020-1, 32 p. https://doi.org/10.14509/30463 
Paces, J.B., and Miller, J.D., Jr., 1993, Precise U-Pb ages of Duluth Complex and related mafic intrusions, northeastern Minnesota: Geochronological insights to physical, petrogenetic, paleomagnetic, and tectonomagmatic processes associated with the 1.1 Ga Midcontinent Rift System: Journal of Geophysical Research, Solid Earth, v. 98, no B8, p. 13,997-14,013. https://doi.org/10.1029/93JB01159

Solie, D.N., O’Sullivan, P.B., Werdon, M.B., Freeman, L.K., Newberry, R.J., Szumigala, D.J., and Hubbard, T.D., 2014, Zircon U-Pb age data, Alaska Highway Corridor, Tanacross and Nabesna quadrangles, Alaska: Alaska Division of Geological \& Geophysical Surveys Raw Data File 2014-16, 29 p. https:// doi.org/10.14509/27322

Solie, D.N., Werdon, M.B., Freeman, L.K., Newberry, R.J., Szumigala, D.J., Speeter, G.G., and Elliott, B.A., 2019, Bedrock-geologic map, Alaska Highway corridor, Tetlin Junction, Alaska to Canada border: Alaska Division of Geological \& Geophysical Surveys Preliminary Interpretive Report 2019-3, 16 p., 2 sheets, scale 1:63,360. https://doi.org/10.14509/30038

Spencer, C.J., Kirkland, C.L., and Taylor, R.J., 2016, Strategies towards statistically robust interpretations of in situ U-Pb zircon geochronology: Geoscience Frontiers, v. 7, no. 4, p. 581-589.

Stacey, J.S., and Kramers, J.D., 1975, Approximation of terrestrial lead isotope evolution by a two-stage model: Earth and Planetary Science Letters, v. 26, no. 2, p. 207-221. https://doi.org/10.1016/0012$\underline{821 X(75) 90088-6}$

Todd, Erin, Wypych, Alicja, and Kylander-Clark, Andrew, 2019, U-Pb and Lu-Hf isotope, age, and trace element data from zircon separates from the Tanacross D-1, and parts of D-2, C-1, and C-2 quadrangles: Alaska Division of Geological \& Geophysical Surveys Raw Data File 2019-5, 10 p.

Twelker, Evan, ed., 2021A, Geologic investigation of the Ladue River-Mount Fairplay area, eastern Alaska: Alaska Division of Geological \& Geophysical Surveys Report of Investigation 2021-5. https://doi. org/10.14509/30734

Twelker, Evan, 2021B, Chapter F: Economic geology of the Ladue River-Mount Fairplay area, in Twelker, Evan, ed., Geologic investigation of the Ladue River-Mount Fairplay area, eastern Alaska: Alaska Division of Geological \& Geophysical Surveys Report of Investigation 2021-5F. https://doi. org/10.14509/30740

Wilson, F.H., Hults, C.P., Mull, C.G., and Karl, S.M., 2015, Geologic map of Alaska: U.S. Geological Survey Scientific Investigations Map 3340, 196 p., 2 sheets, scale 1:1,584,000. https://alaska.usgs.gov/ science/geology/state map/interactive map/AKgeologic map.html

Wypych, Alicja, Jones, J.V., III, and O'Sullivan, Paul, 2020, U-Pb Zircon ages from bedrock samples collected in the Tanacross D-1, and parts of the D-2, C-1, and C-2 quadrangles, Alaska: Alaska Division of Geological \& Geophysical Surveys Preliminary Interpretive Report 2020-2, 19 p. https://doi. org/10.14509/30465

Yukon Geological Survey, 2019, Yukon Digital Bedrock Geology. www.geology.gov.yk.ca/ update yukon bedrock geology map.html [accessed: March 19, 2019] 2020, Yukon Geochronology - A database of Yukon isotopic age determinations: Yukon Geological Survey. http://data.geology.gov.yk.ca/Compilation/22 [accessed: February 1, 2021] 


\title{
APPENDIX A
}

\author{
PALEOGENE SAMPLES
}

PPL images on the left and XPL on the right.

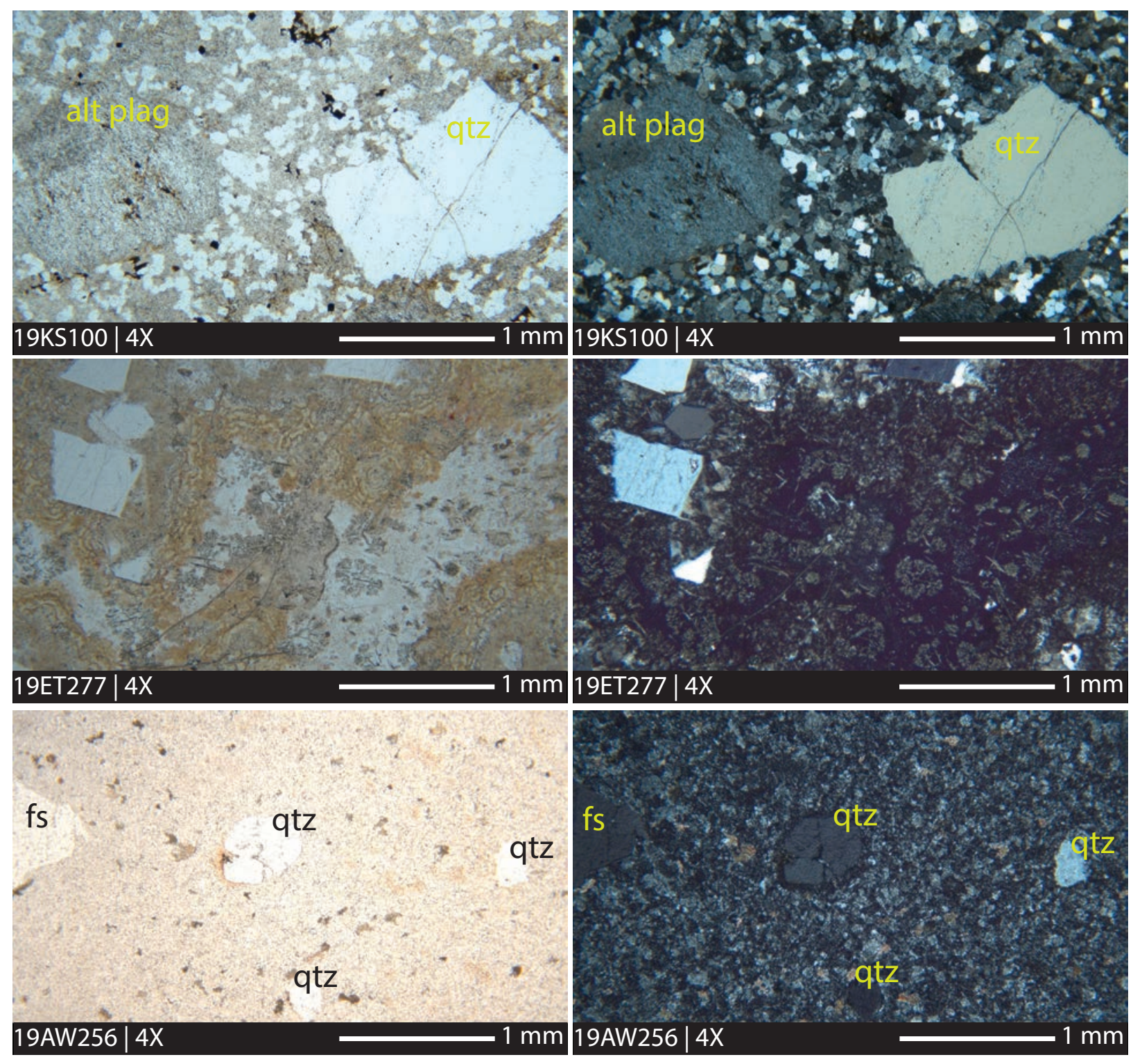




\section{LATE CRETACEOUS INTRUSIVE SAMPLES}

PPL images on the left and XPL on the right.

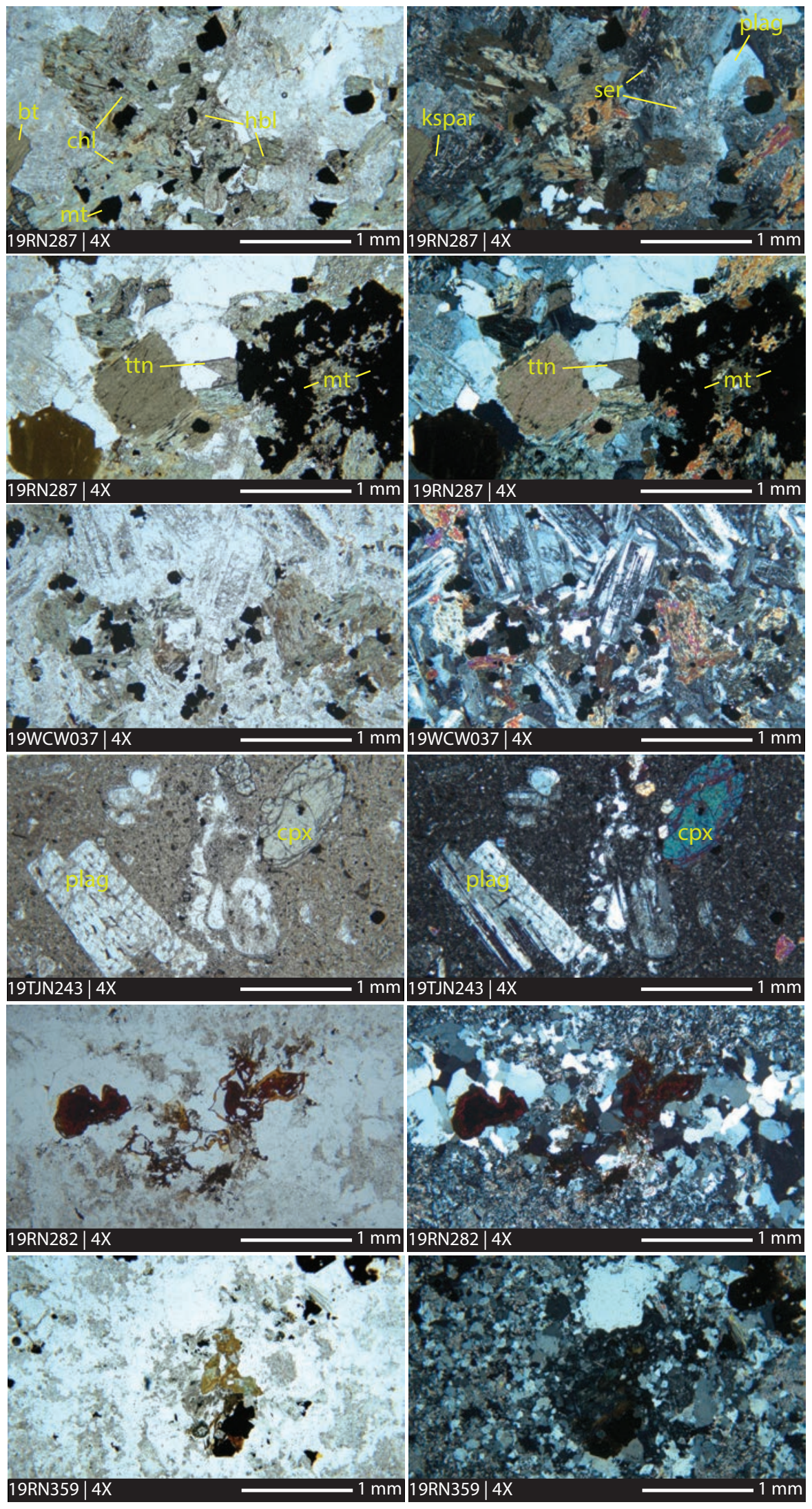




\section{MID CRETACEOUS SAMPLES}

PPL images on the left and XPL on the right.

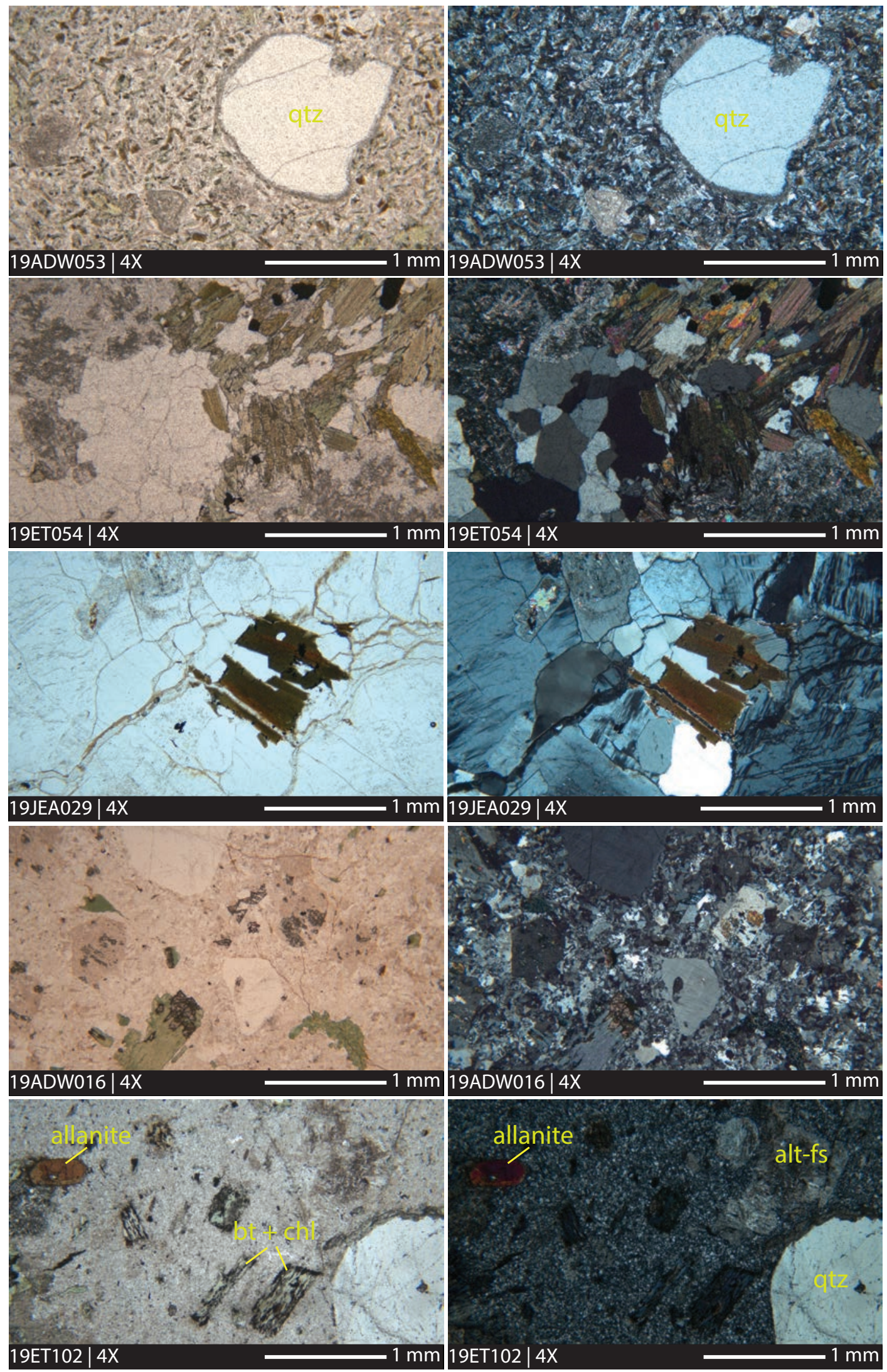




\section{MID CRETACEOUS SAMPLES, CONTINUED}

PPL images on the left and XPL on the right.

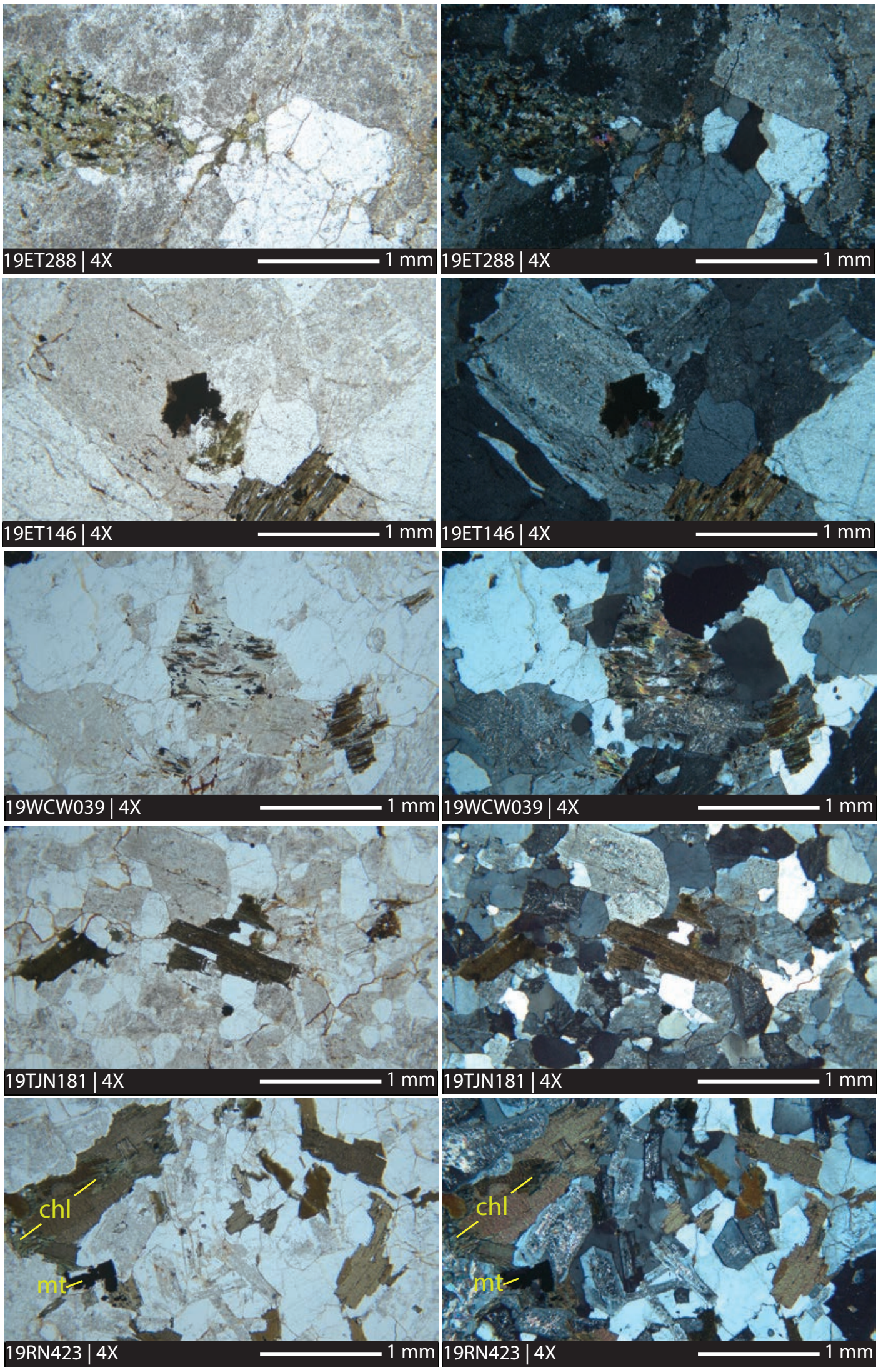




\section{MID CRETACEOUS SAMPLES, CONTINUED}

PPL images on the left and XPL on the right.

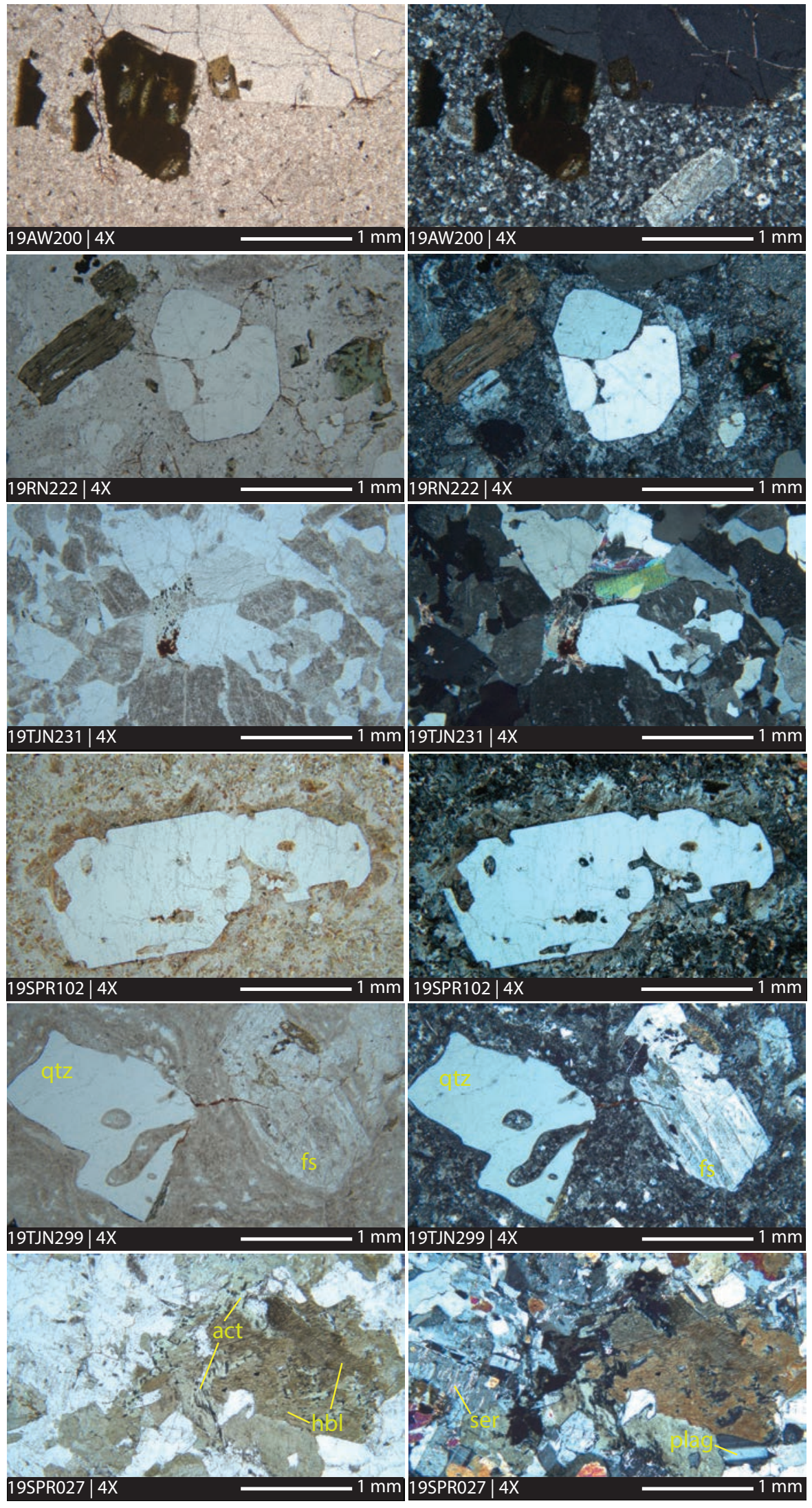




\section{ALLOCHTHONOUS KLONDIKE ASSEMBLAGE SAMPLES}

PPL images on the left and XPL on the right.

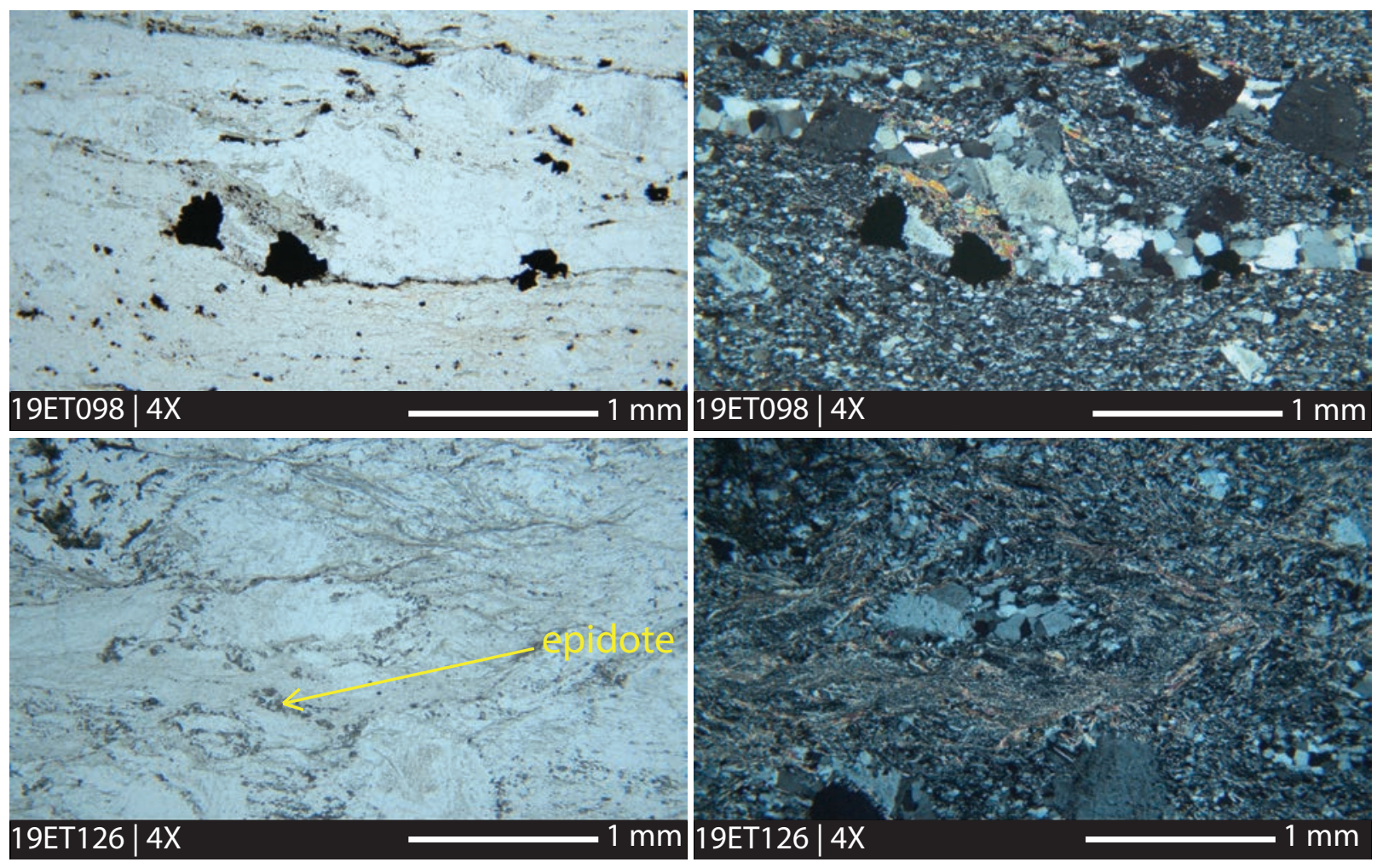




\section{ALLOCHTHONOUS LADUE RIVER UNIT SAMPLES}

PPL images on the left and XPL on the right.

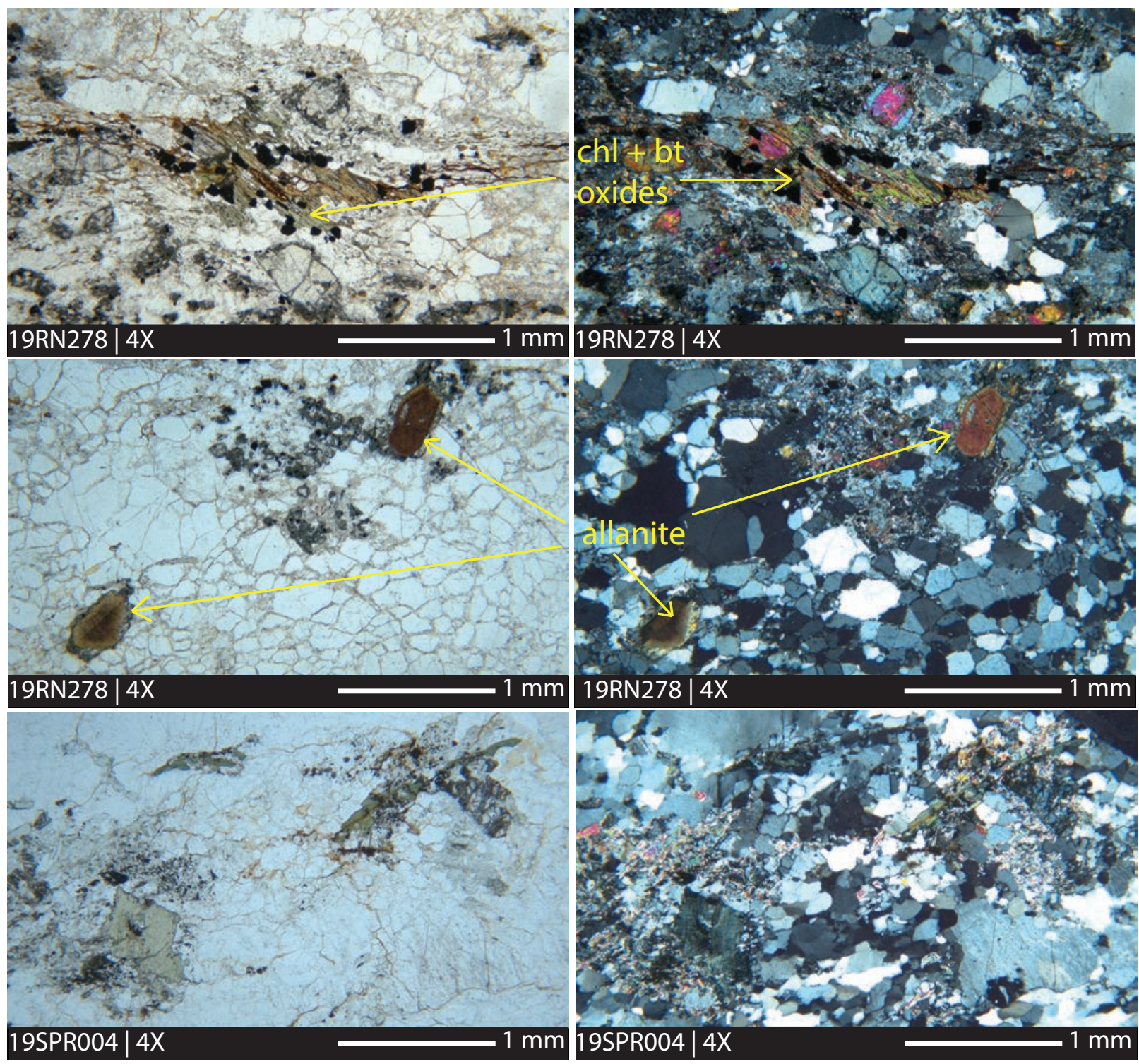




\section{ALLOCHTHONOUS LADUE RIVER UNIT SAMPLES, CONTINUED}

PPL images on the left and XPL on the right.

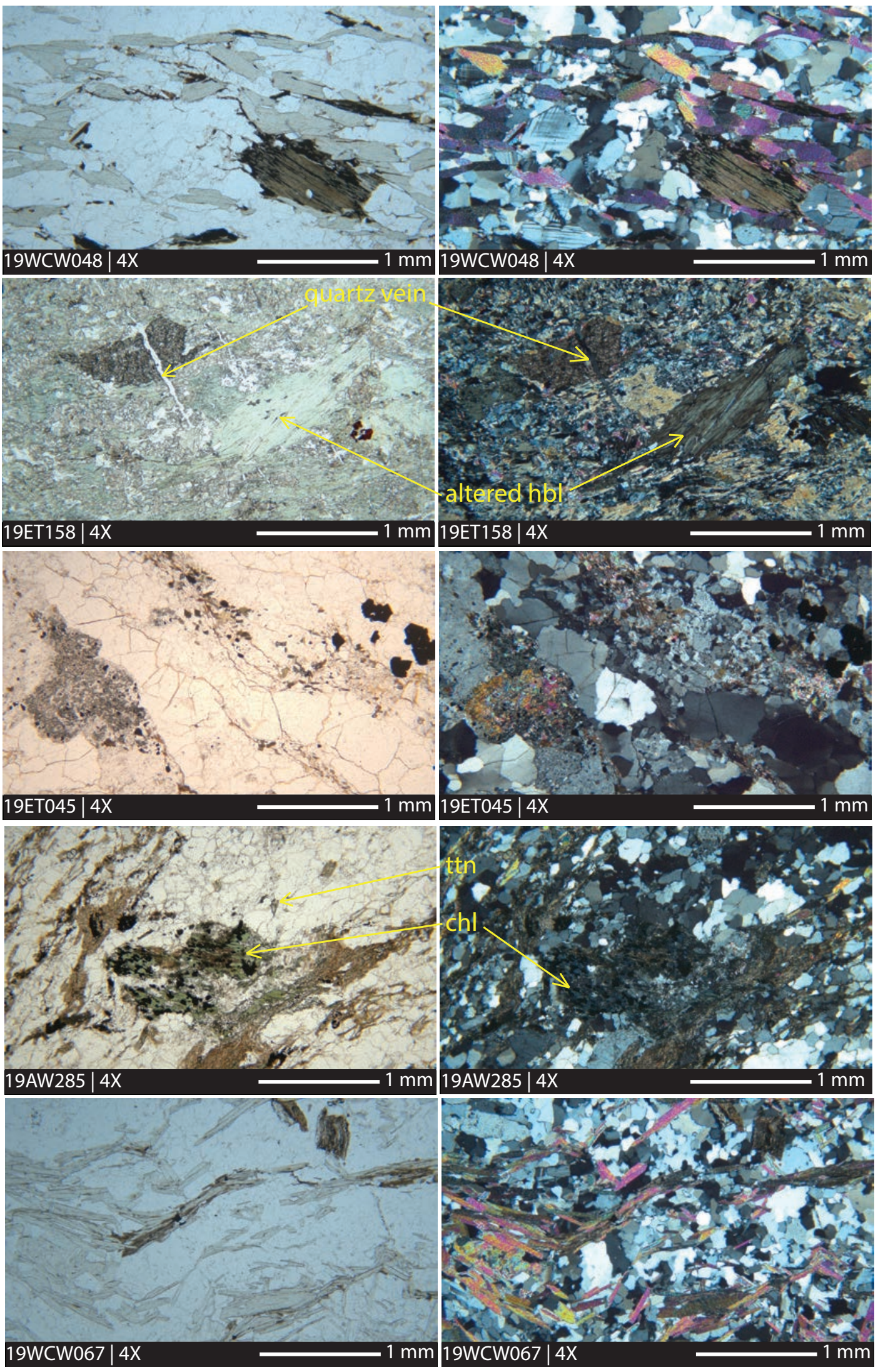


PARAUTOCHTHONOUS LAKE GEORGE ASSEMBLAGE SAMPLES

PPL images on the left and XPL on the right.

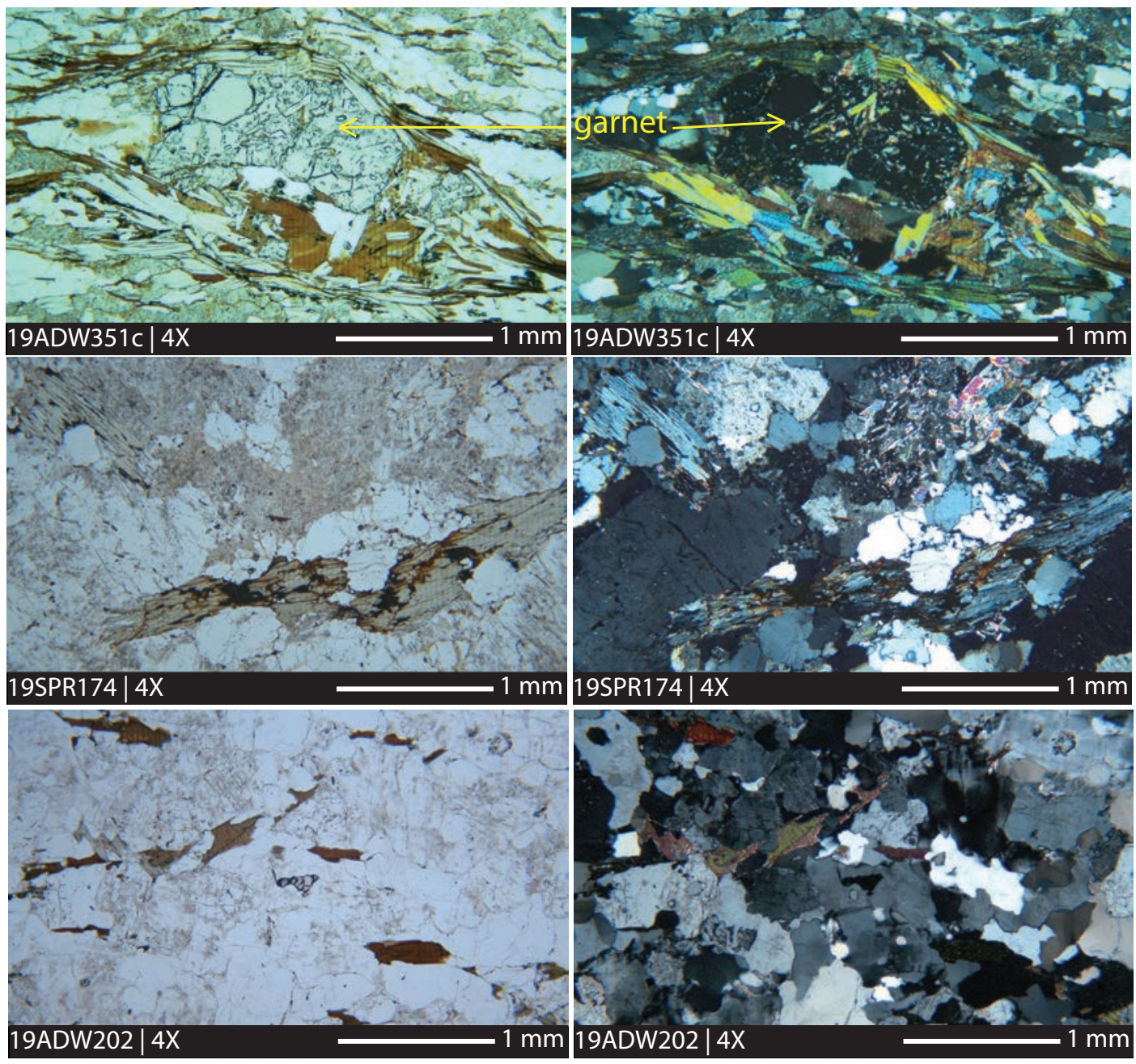

PARAUTOCHTHONOUS JARVIS BELT SAMPLE

PPL images on the left and XPL on the right.

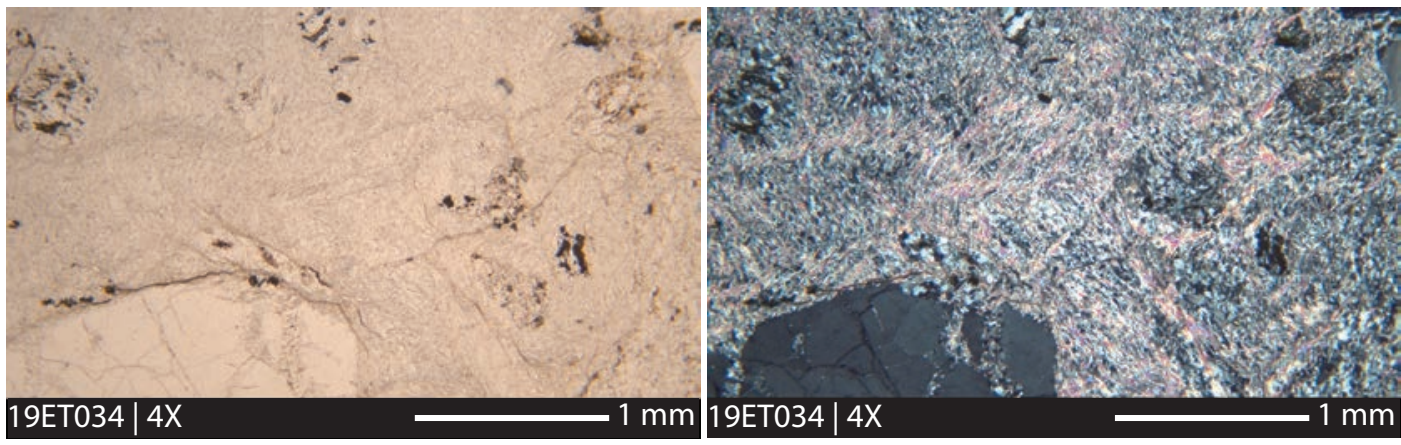

